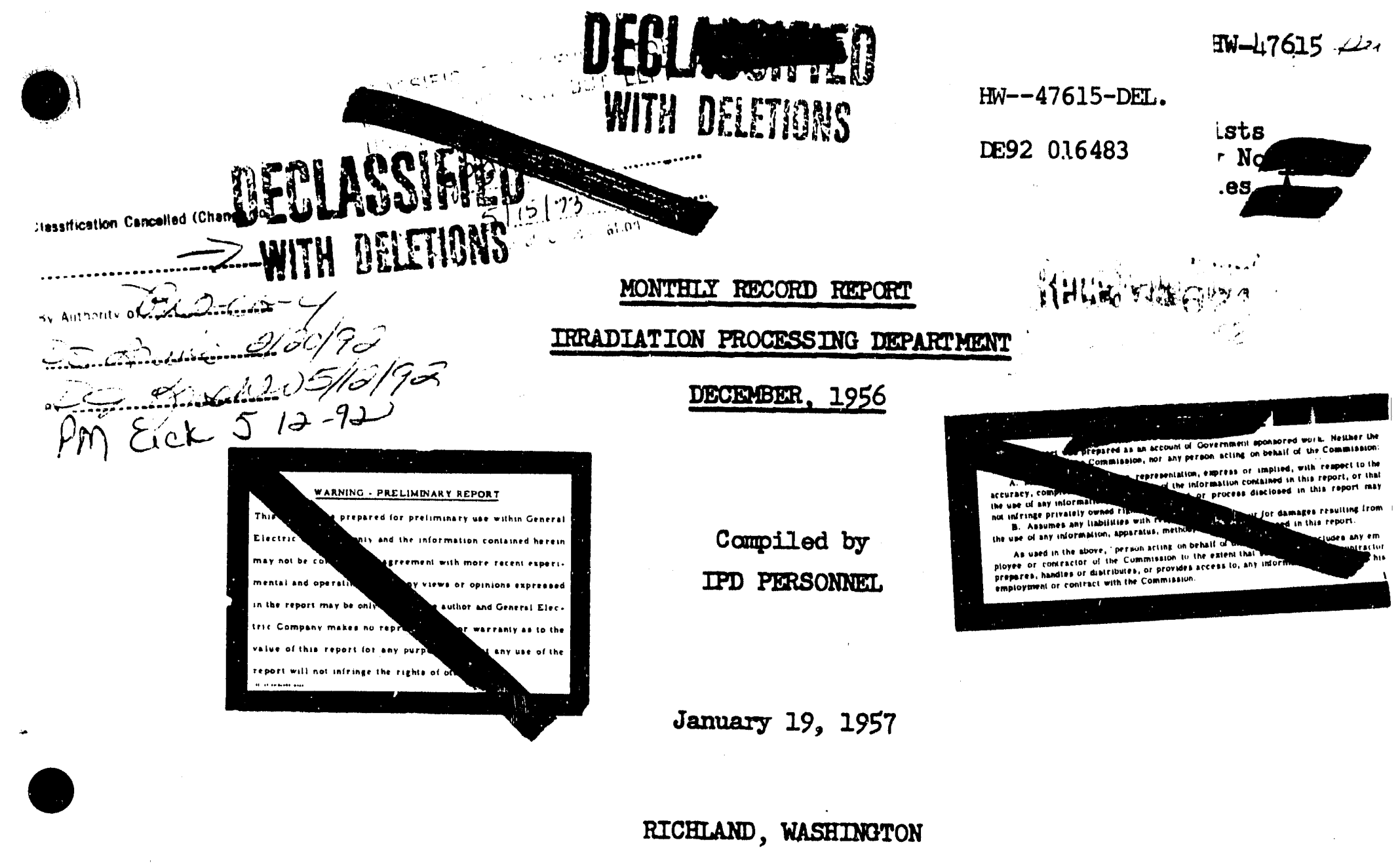

Work performed under Contract No. W-31-109-Eng-52 between the Atomic Energy Commission and General Electric Compan

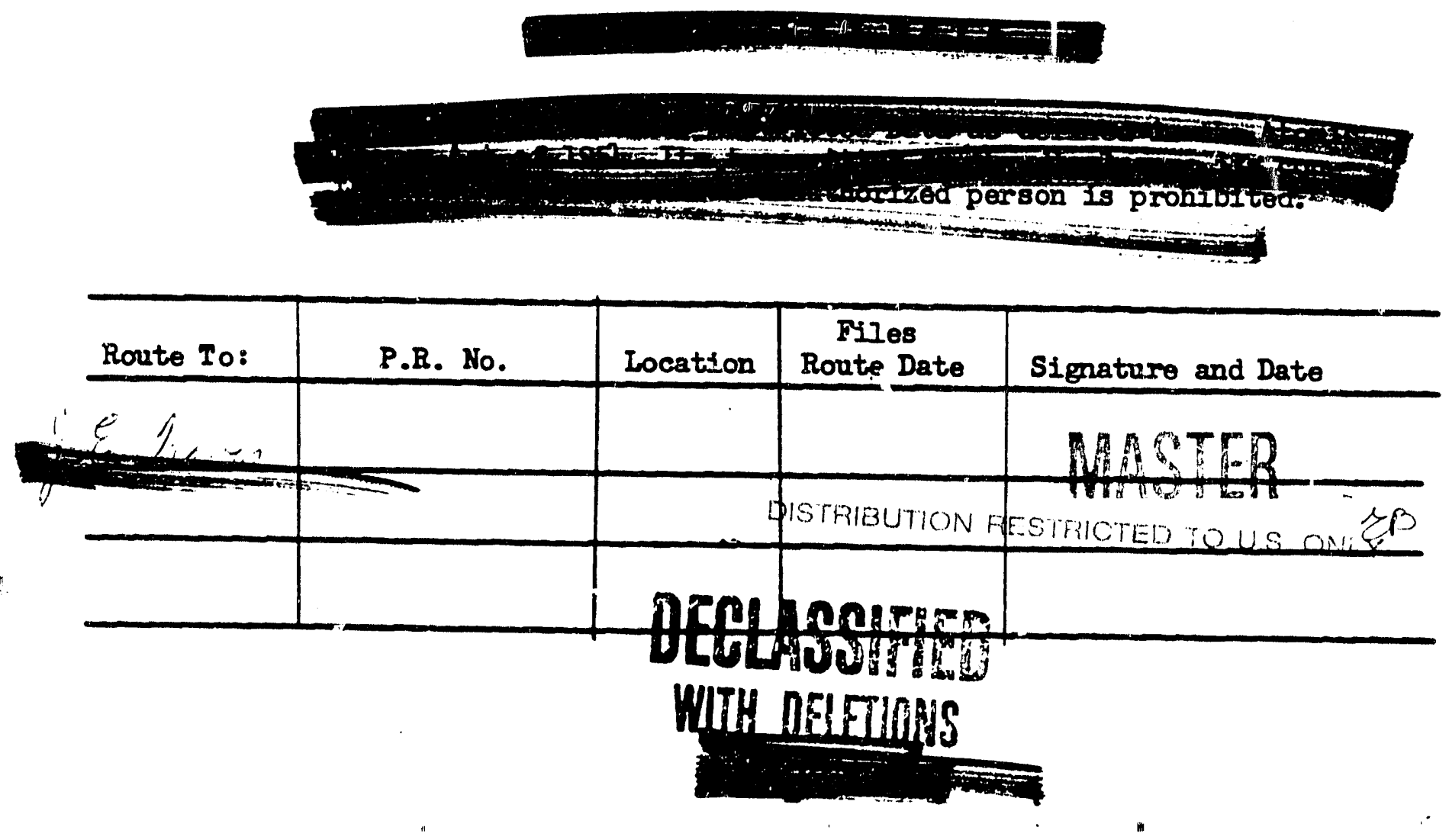




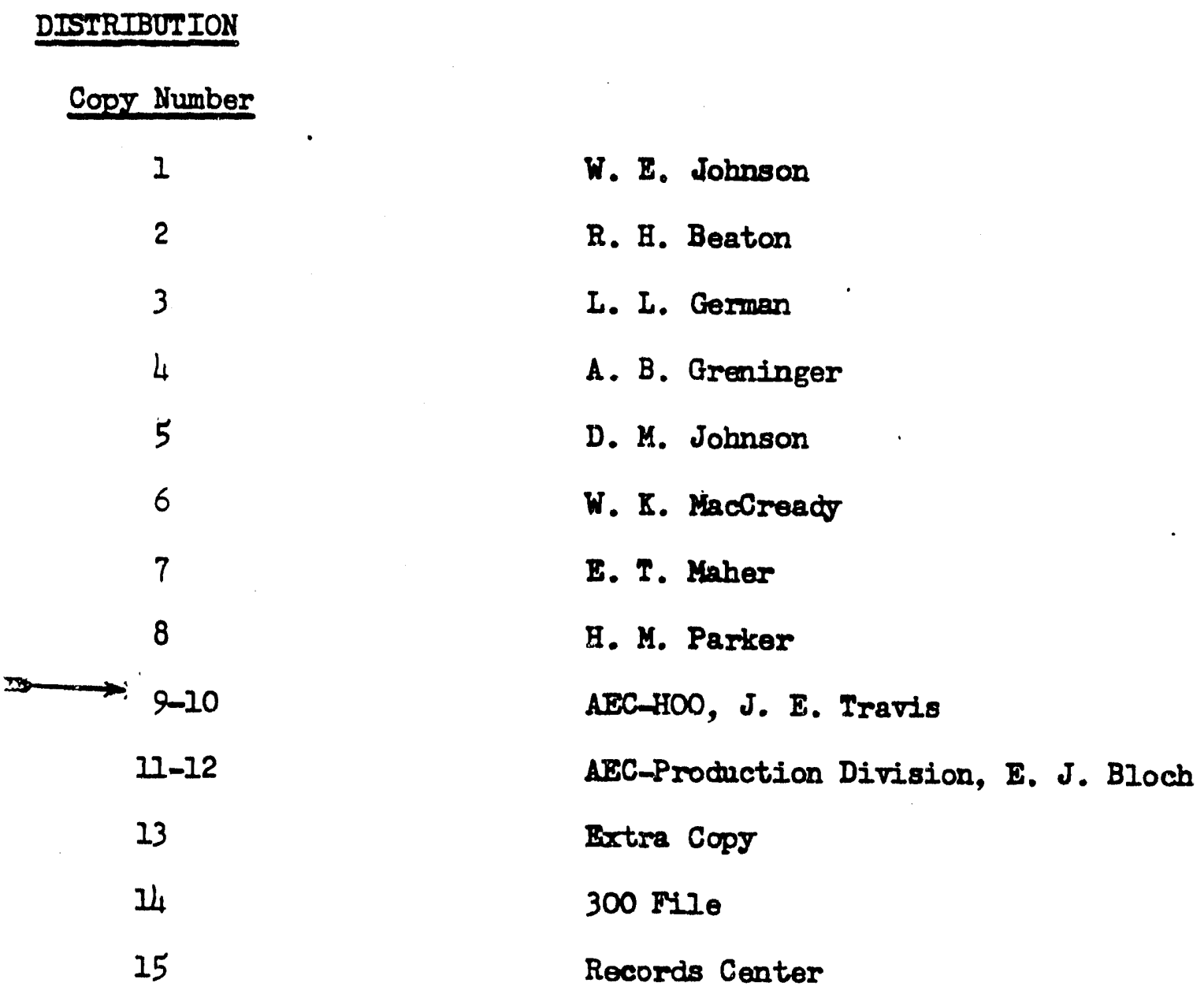


General Summary ..................... A-I through A-5

Research \& Engineering Operation ............. B-I through B-35

Process and Reactor Development Operation ......... B-2 through B-12

Process Technology Operation ............ B-13 through B-18 Operational Phssics Operation ............. B-19 through B-26

Irradiation Testing Operation ............ B-27 through B-30

Coolant Testing Operation .............. B-31 through B-33

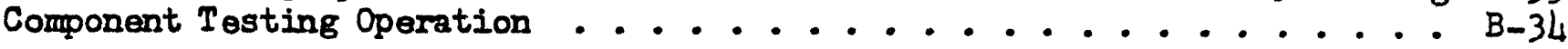

Production \& Reactor Operations . . . . . . . . . . Ca-l through Ch.-6

Summary ........................... Ca-1 B.C Reactor Operation .............. Cb-1 through Cb-12 KE-KW Reactor Operation ................ Cc-1 through Cc-10 D-DR Reactor Operation................ Cd-I through Cd-9 H Reactor Operation ................. Ce-l through Co-10 F Reactor Operation .................. C $f-1$ through $\mathrm{C} f-9$ Reactor Operations Statistics ............. Cg-I through $\mathrm{Cg}-6$ Production Operation ..................... Ch-1 through $\mathrm{Ch}-6$

Facilities Engtneering Operation ............ D-1 through D-35

Employee Relations Operations ............... E-I through E-13

Persomel Development \& Communications Operation ........ E-1 through E-3 Health \& Safety Operation . . . . . . . . . . . . . . . . E-4 Personnel Practices Operation ............ E-5 through E-8 Salary \& Wage Administration Operation ........... E-9 through E-10 Union Relations Operation .............. E-11 through E-12

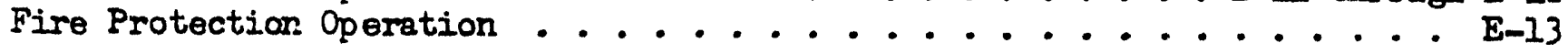

Financial Operation ....................... F-I through F-3

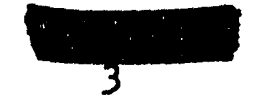




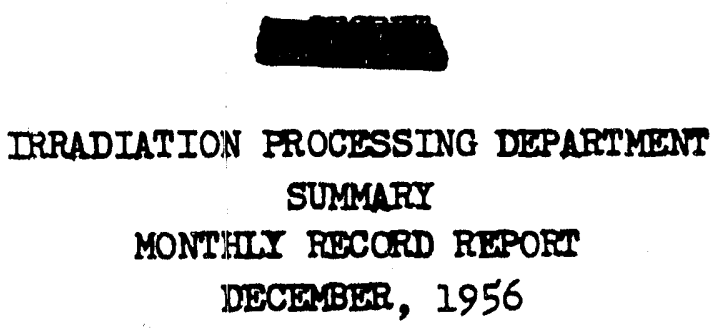

HW -47615

\section{IRRADIATION PROCESSING DIMPARTMEATI \\ SUMMARY \\ DECEMIBER, 1956}

RESEARCH AND ENGINEGTING OPERATION

At C Reactor the four tube run-to-rupture test (PI 105-615-4-63-AI) of I \& E slugs attained exposures of approximately $1500 \mathrm{wD} / \mathrm{T}$ without failure. The last two tubes of the four control tubes of solid slugs were discharged after the second failure at $1250 \mathrm{mD} / \mathrm{s}$ last month. A second loading of 50 tubes of the pilot ir radistion was also accomplished and two new process tubes were installed with provision for detailed annular monitoring of outlet water temperatures and "shortcharged" (25 slug column) to further study the "eccentricity" effect.

At B Reactor two 12 tube blocks were loaded with enriched metal to evaluate E-siug stability and in pile conversion ratio for tritium and plutonium production associated with $\mathrm{E}-\mathrm{N}$ loadings.

Measurements made by the Hanford Laboratories Operation concerning conditions under which there would be cavitation in fringe tubes that have double orifice assemblies were evaluated in terms of present and predicted reactor conditions. Recommendations were made, where necessary, to increase the margin of safety for effective Panellit protection.

Difficulties in water treatment caused by an umsual increase in river water turbidity were minimized in areas with Separan feed facilities; at 183-B the performance was exceptionaliy good even at CG-558 flow rates.

The KIBR tie-in made curing the period of 12/11-21/56. Testing was not completed but will be performed during regularly scheduled outages of the reactor.

PRODUCTION AND ERACTOR OPERATIONS

Input production (Pu) for December was 210.5 per cent of forecast and represents a new record, exceeding the October, 1956 record by 4.0 per cent. This achievement resulted from record procuction at the IR and KN Reactors (exceeding previous highs by 13.7 and 10.8 per cent, respectively), and from above forecast power levels and time operated efficiencies.

Output production for December was 107.5 percent of forecast che to discharges during unscheduled outages late in the month. Discharge concentrations were maintained according to previous plan, including the redefinition of rupture-prone tubes to accoimt for the drop in inlet water tamperature experienced at this time of year.

Increasen in the maxdmum established power levels (Including burnout) were achieved at $B, \mathrm{DR}$ and $\mathrm{WW}$ where previous records were exceeded by 90,5 and 60 untts, respectively. These increases resulted from additional cooling water following the installation of project CQ-558 facilities at B Reactor, good contimaity of operation at DR and improved flattening at $\mathbb{K}$.

Thirty-nine reactor outages, of which fourteen were scrams, resulted in an overall time opereted efficiency of 77.1 per cent. Forecast was 75.0 per cent.

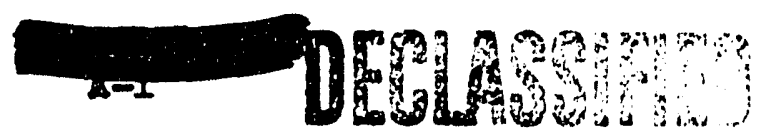


Fifteen ruptures of regular metal slugs required 172.2 ontage hours for removal from the resctors. Five of these occurred at $C$, five at $B$, two at $K W$ and one each at $D, F$ and KIS. Three ruptores were removed by the "quickie" method; ane each at $C$, $B$ and $K W$.

Oncler the tube replacement program, tubes were installed in 19 channels from which problem tubes had boen prevlonsly removed at B keactor, 49 tubes (including 24 problem tubes) were removed and replaced at 8 , and 75 regular tubes were removed and replaced at $\mathrm{H}$.

Significant items of equipment experience during the month were: (I) the KE Reactor was shut dorn Docember 17 to 22 for the tie-in of the 1706 KIMR facility; (2) B Reactor resumed operation December 8 concluding an outage for the installatjon of CQ-558 facilities; (3) \& BPA power failure, caused by the opening of a relay on the No. 2 BPA line at Lidway, scrammed the D, F, II and Reactors December 27. D and KE were unable to recover from the scram due to insufficient reactivity; (4) Suparan feed facilities were completed at all water plants except $F$ and $k$ r

There were no disabling injaries during the month. One formally-investigated Radiation Incident was experieviced at IN when a Processing Operation employee received a localized overmexposure to his hand from particulate contamination as result of handing a contaminated hose nozzle.

Statistics for the Processing, Power, and Radiation Monitoring Operations in the individual reactor areas are tabulated on pages $C_{g}-1$ through $C_{g}-6$ of this report.

\section{FACIIITIES ENGINETRTNG OPERATION}

Construction completion status of major process facilities at the end of December was as follows:

Project Number

CA- 512

$\mathrm{CA}-512$

CG-558-I

CO-558-II

CG-600
Titio

100-K Area Pacilities, Revisions Nos. 3 \& 4 1706-KER Recirculating Facilities Reactor Plant Modifications Reactor Plant Modifications 100-C Alterations
Cormletion

Schedule* Actual $100 \%$ - $\frac{100 \%}{10 \%}$ $99 \% \quad 99 \%$

$77 \% \quad 85 \%$

$50 \% \quad 48 \%$

$53 \%$. $25 \%$

* Per certified schedule or directive completion date.

* Complete except for revisions and start-up items.

Completion percentages for the design of reactor and reactor buildings on Project CG-654, "Advance Reactor Design", are summarized as follows:

\begin{tabular}{lcc} 
& Last Month & This Month \\
\cline { 2 - 3 } Drawings & $78 \%$ & $100 \%$ \\
Criteria & $88 \%$ & $95 \%$ \\
Testing & $47 \%$ & $51 \%$ \\
Weighted Overall & $73 \%$ & $83 \%$
\end{tabular}

Kaiser Engineers effort for this project remains at 85 percent complete.

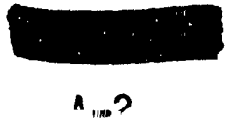


A transit traverse made on vertical safety rod number 23 in the KE Area shows alignment deviation approaching one-fourth inch. 'Scratching was evident for approximately three-fourths of the observed length and one section shows evidence of galling. Deviation and frictional tests on three of the worst offending rads are being initiated.

Investigation of excessive vibration in the 190 to 105 Buildings process water line resulted in a new design of the by-pass process water line which utilizes a series of orifices. A test installation in DR has greatly reduced vibration, virtually eliminated evidence of cavitation, and reduced the noise level. By-pass line modifications will be made in all areas.

The CG-558 outage was completed in 100-B Area on December 8, 1956, and the $\mathbb{R R}$. shutdown was scheculed for January 7, 1957. A target schedule for the outage duration in $\mathrm{DR}$ was established at seven weeks.

EMPLOYEE RETLATIONS OPERATION

Four Professional Business Management I courses in the Department have been scheduled to start in January. The first Nonexempt Personnel Development Program appraisal forms were distributed to supervisors having employees with continuityof-service dates in January. Craft training session on Ram-Set Powder-Actuated tools was completed. There was a noticeable increase in the tempo of re-evaluations in the Supervisory Selection Program.

The Department Rescue Crew Program has been completed with training activities planned throughout 1957. The Civil Defense Program is being reviewed with the Atomic Energy Commission insofar as the current requirements of personnel remaining in Power House areas are concerned. Ninety work restriction cases have been reviewed since September 1, 1956.

The Manager - Personnel Practices presented a speech at the University of Colorado on December 12. Referral activity was high during the month, and a number of prospective technical employees have been invited to visit during the next six weeks. Arrangements have been made for placing several CPD technical men in IPD. Pour college professors have also been lined up for summer positions within IPD. Employment activity again involved considerable work relative to transfer requests, 22 additional requests being recelved upon transfer of records from Relations and Utilities. Employee Benefits and Services distributed an informational package on insurance claims to each employee. Much effort was devoted to the development of up-tomdate information on milltary service status, preparatory to canvass which will be held next.month. A new duplicating facility was established in 100-D Area. In addition, mail carts were provided for heavily populated buildings, and portable mail distributors were provided for mail personnel.

Instructions and schedules were established to provide for completion of the appraisal program by January 15, 1957. Bequests were drafted for Commission approval of revisions to the Salary Administration Manual, relative to the change of the Fire Chief positjion from the fixed rate schedule, and for the establishment of new secretarial classifications.

Approximately one-half of the Department grievances processed at Step II during

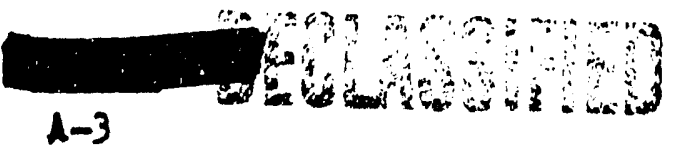


the month involved work assignments wich the Councll alleged have deviated from our past practice. Submission of a joint petition by the Banford Atomic Metal Prades Council and the Company was made to the National Labor Relations Board for a determination as to whether work in the 1706work. Union ches check-off flgures for December show that $63.2 \%$ of the bargaining unit employees in IPD are signed up for check-off, compared to a plant average of $54.4 \%$.

There were no fires in December or November. This is the firs: time in 10 years that 60 days have elapsed without a fire.

\section{FINANCIAL OPERATION}

A review of the Bquipment Budget was made to determine the additional funds required for the balance of FI 1957. A letter was drafted to the General ManagerEAPO requesting additional funds.

Analysis was made of Research and Development and Process Technology Cost in comparison with allotted funds for the Manager Research and Engineering Operation.

Effective December 1, 1956 isolation pay and area differential were included in earnings for insurance purposes.

Employee and Timekeeping data pertinent to the problem of installation of time recorders for noneximpt employees in IPD was compiled and reported.

Study was continued on teletype of facsimile commications system and automated procedures, to help in overcoming communications problems.

A total of 13 OPD's and Advices were released for publication and distribution during the month. In addition, 12 previously published Advices were revised and issued, incorporating improved procedures developed subsequent to initial issue. 


\title{
IRRADIATION PROCESSING DGPARAMENT
}

\section{MONTHLY PRIPORT OF INVHNTIONS OR DISCOVERTES}

DECEMBER, 1956

\begin{abstract}
All persons engaged in work that might reasonably be expected to result in inventions or discoveries advise that, to the best of their knowledge and belief, no inventions or discoveries were made in the course of their work during the period covered by this report except as listed below. Such persons further advise that, for the period therein covered by this report, notebook records, if any, kept in the course of their: work have been examined for possible inventions or discoveries.
\end{abstract}

Name

Evan W. Baker

E. R. Rudock
Title

Audible Railroad Crossing Warning

Flange Seal - (providing a variable compression while maintaining a seal)

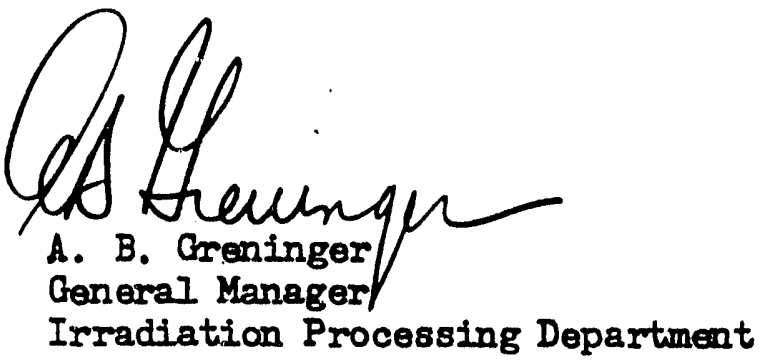

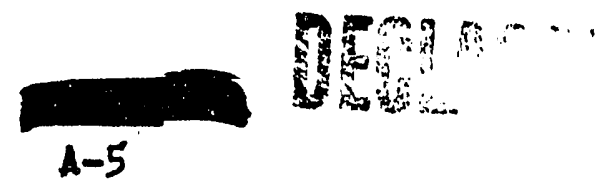




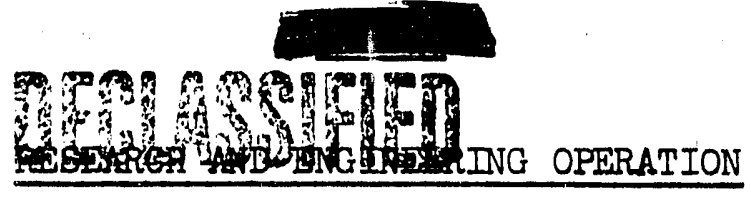

$H W-47615$

DECEMBER, 1956

\section{VISITORS AND BUSINESS TRIPS}

A. W. Thiele, Process and Reactor Development Operation, visited the Goodyear Aircraft Corporation in Akron, Ohio from December 1 to December 8, 1956 for field testing of the analog computer being fabricated for HAPO.

S. S. Jones, Process and Reactor Development Operation, attended the annual meeting of the AIChE at Boston, Mass. and also consulted with Messrs. Menzel of Harvard University, Markels and Stein of Columbia University on heat transfe: problems; December 8-18, 1956.

N. R. Miller, Process and Reactor Development Operation, attended an information exchange meeting on aluminum corrosion at Chalk River, Canada, December $14-22,1956$.

ORGANIZATION AND PERSONNEL

Management and Administration

Process and Reactor Development Operation

Process Technology Operation

Operational Physics Operation

Irradiation Testing Operation

Coolant Testing Operation

Component Testing Operation

\begin{tabular}{|c|c|c|c|}
\hline \multicolumn{2}{|c|}{ P manent } & \multicolumn{2}{|c|}{ Rotational } \\
\hline NC.. & Dec. & Nov. & $\overline{D e c}$ \\
\hline 4 & 4 & & \\
\hline 26 & 26 & 2 & 3 \\
\hline 34 & 34 & 9 & 7 \\
\hline 19 & 19 & 8 & 5 \\
\hline 20 & 20 & 4 & 5 \\
\hline 22 & 23 & 3 & 3 \\
\hline 22 & 22 & 2 & 1 \\
\hline 147 & $7 / 48$ & 28 & \\
\hline
\end{tabular}

Coolant Testing Operation: E. I. Burley, Engineer I, transferred into the Operation from the Chemical Processing Department on $12 / 1 / 56$.

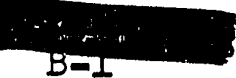




\section{PROCESS AND BEACTOR DEVELOPNENT}

\section{REACTOR FUEIS}

\section{Internallow-Externall Cooled Flements}

The four tube internally and externaliy cooled slug run-to-rupture test (Production Test 105-615-A-63-MT) continues at C-Reactor. The I \& $E$ colums have .ow attained exposures approximating $1500 \mathrm{MWD} / \mathrm{T}$ without failure; two of the four control colums failed earlier - one at $850 \mathrm{MWD} / \mathrm{T}$ and the other at $1250 \mathrm{MWD} / \mathrm{T}$ - and the remaining two control columns were discharged last month following the $1250 \mathrm{MWD} / \mathrm{T}$ failure.

The second loading of a fifty tube increment was accomplished without significant incident. In addition two new process tubes were installed and "short-charged" with a twenty-five slug column with provision for detailed annular monitoring of outlet water temperatures to further study the "occentricity" effect.

Additional information regarding the eccentricity effect has been obtained from thermocouple assemblies now operating. For the average corroded tube the ratio of the temperature rise in the coolant at the top of the annular channel to that in the bulk tube flow is about 1.4 with about seventy-fire percent of this directly attributable to the eccentric tube-charge geometry. In new tubes this ratio is nearly 1.8 whereas it approaches unity in tubes with advanced corrosion attack. As a temporary measure I \& $\mathrm{E}$ column length is being established according to the tube corrosion indices; it is deemed that one-fourth of the C-Pile tubes can safely, accommodate full length I \& $E$ charges, and the remainder will need to be short-charged in rarying degrees.

\section{Cocked Slugs}

Five additional charges containing severely cocked slugs (irradiated under Production Test 105-634-A) were discharged at about $400 \mathrm{MWD} / \mathrm{T}$. Preliminary observation of the discharged pieces reveals that, while all observations are qualitatively the same as those performed on the four tubes of $200 \mathrm{MND} / \mathrm{T}$ charges discharged last month, the localized corrosion attack appears mach more severe at the higher exposures. It is not jet known whether this corrosion attack is intergranullar or accelerated uniform corrosion in nature. Eighteen charges containing cocked slugs and five control charges continue to be irradiated under this program. Radiometallurgical examination of selected pieces has been scheduled.

Active Production Tests - Fuels Development

Table I lists the active fuel development production tests and includes a brief remark regarding the status of each.
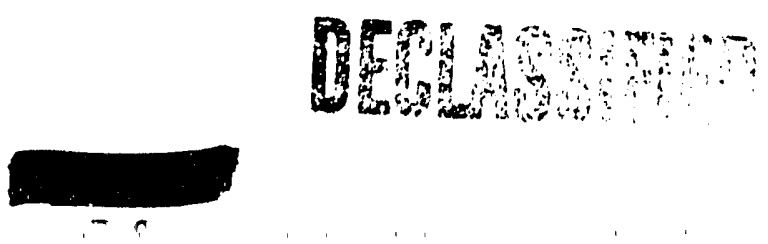

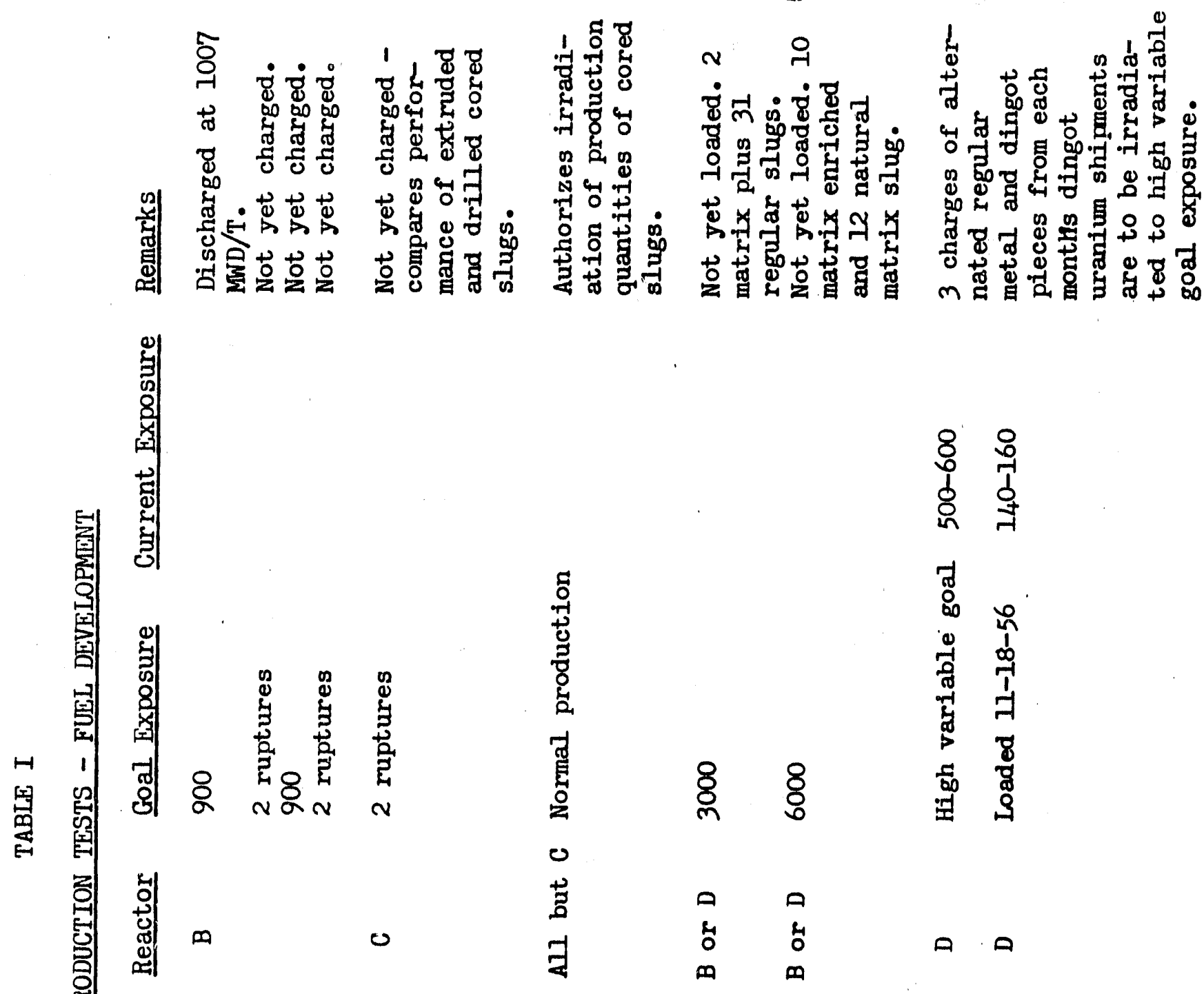

तt

- -1 กั

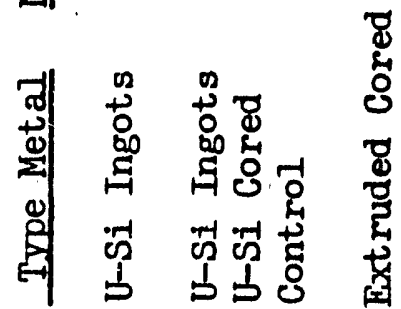

苨

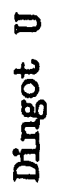

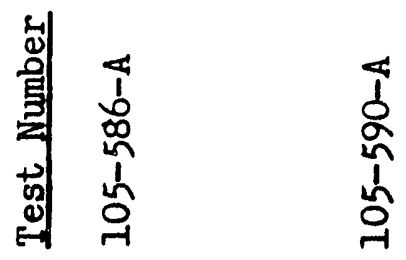

ఫ

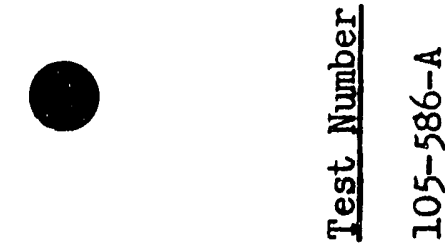

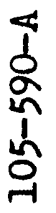

望

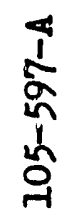

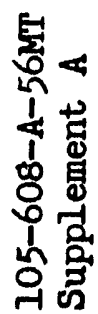



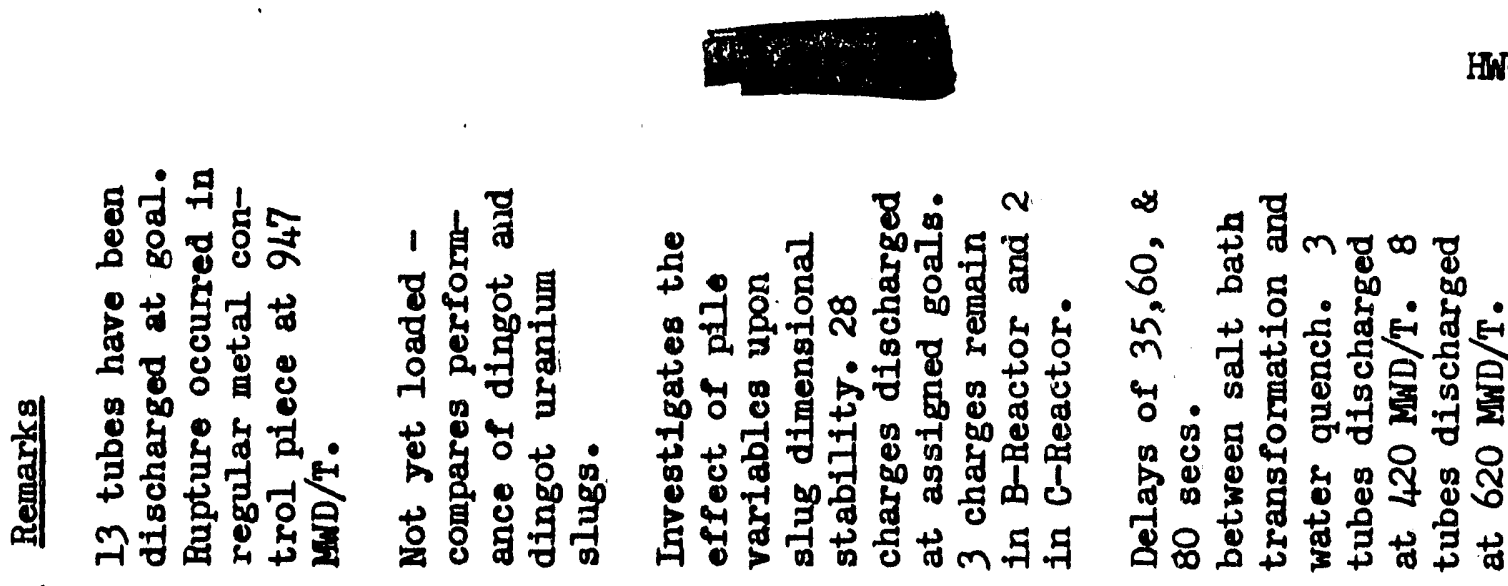

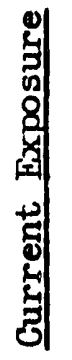

옹
ôे
ूू

8
$\infty$
1
0
$\infty$

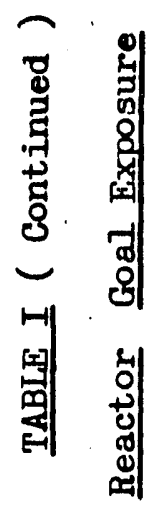

8
7
8
8
8
8

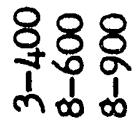

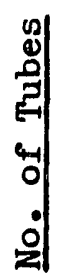

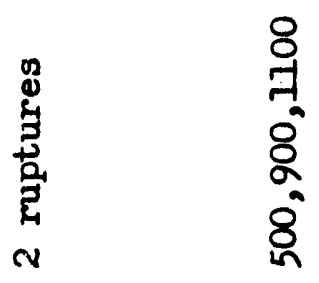

品

5

क्ञ

$+\quad m$

ब.

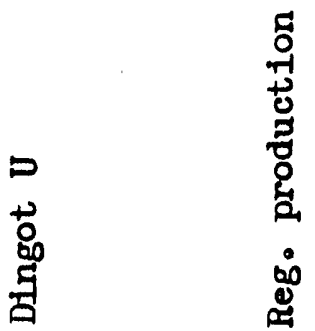

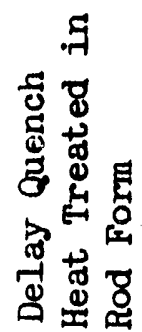

章

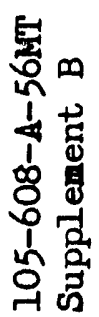

年 


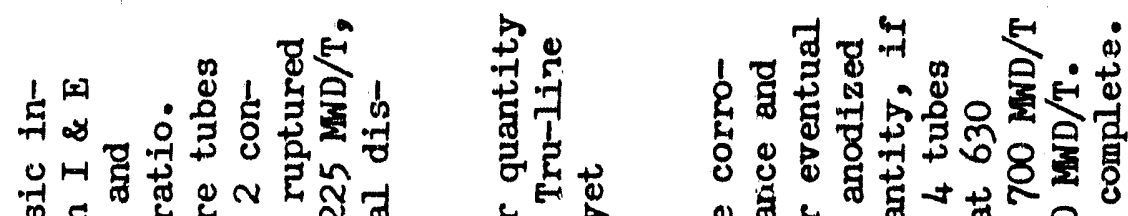

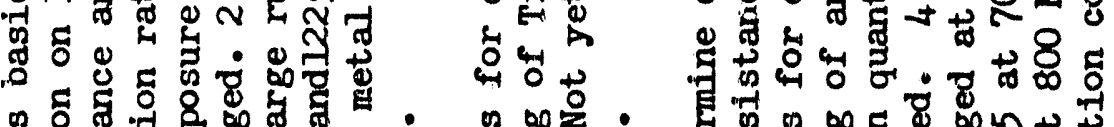

:

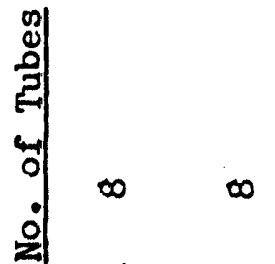

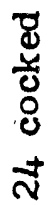

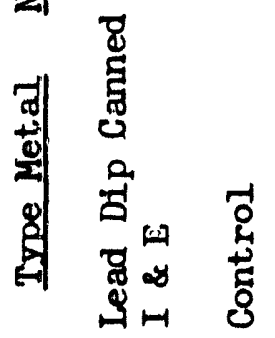

兽

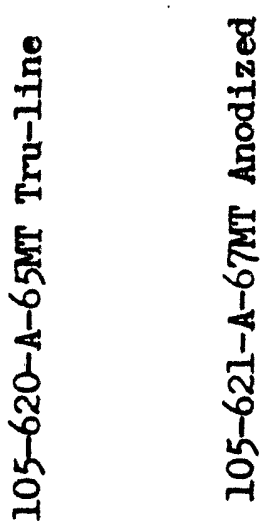

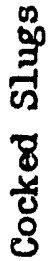

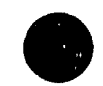

$\stackrel{0}{ }$

采

$\frac{1}{4}$

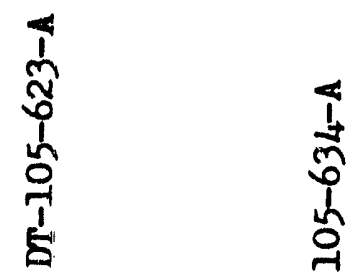



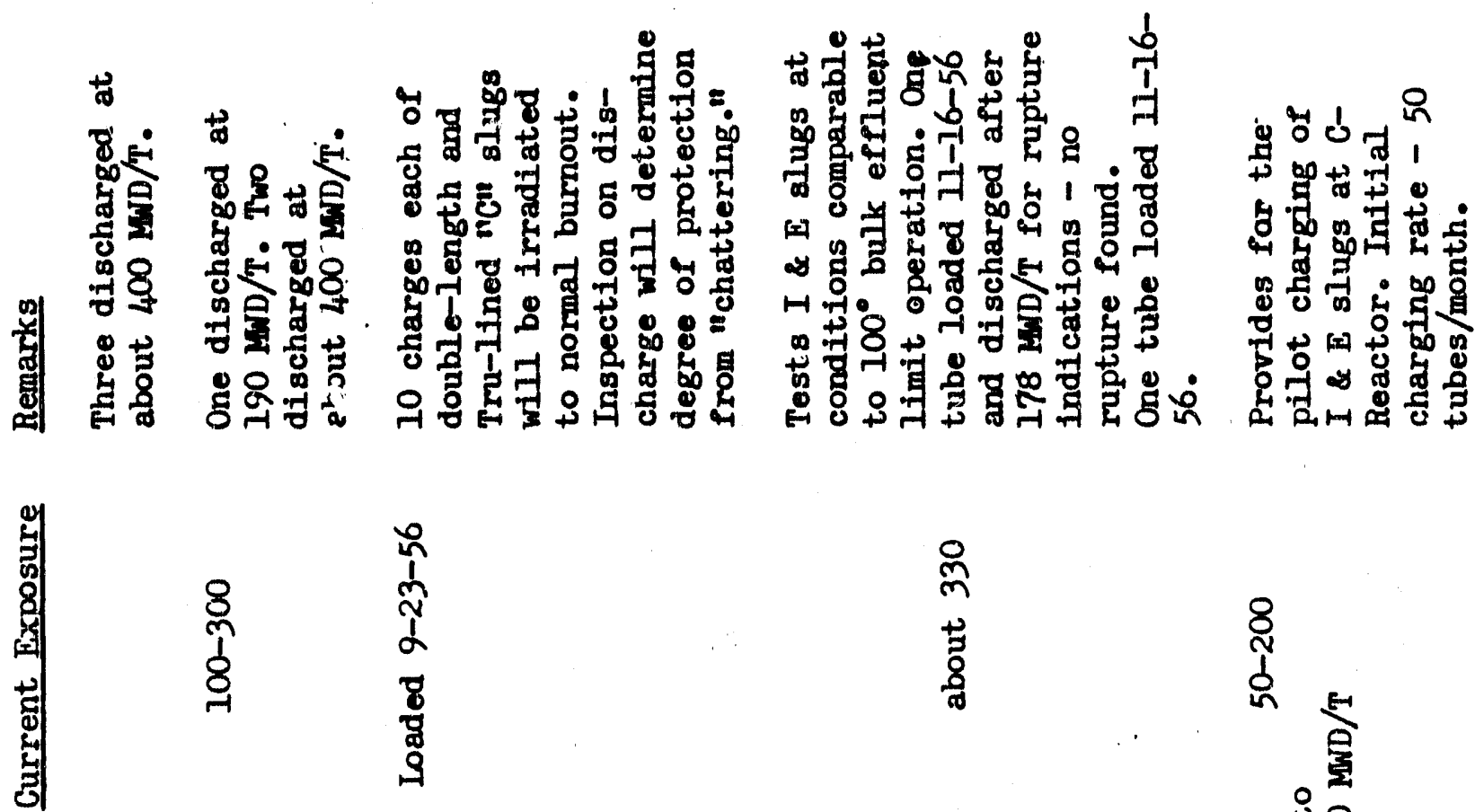

0
$m$
+
8

유ํ

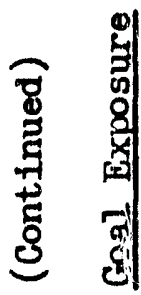

8
0
8
8
8
8

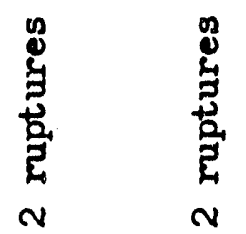

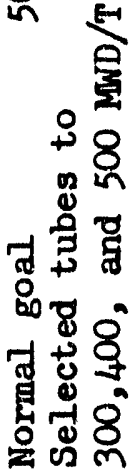

武 辣

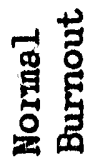

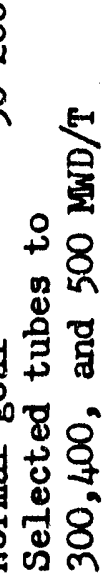

है।

-1
8
+10
0
0
$\infty$

0

0

0

a्d

ชิ

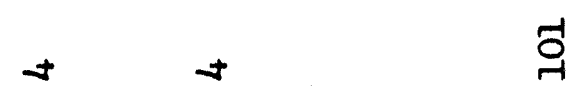

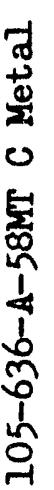

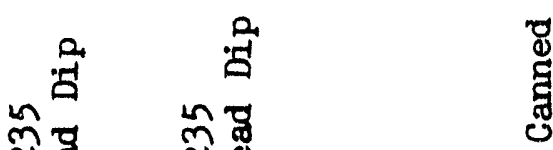

๖.

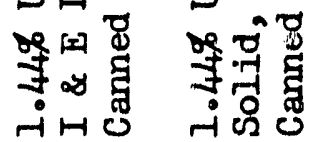

मี่

包

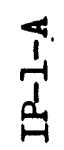

4
$\frac{1}{2}$
$\frac{1}{2}$
$\frac{1}{4}$ 


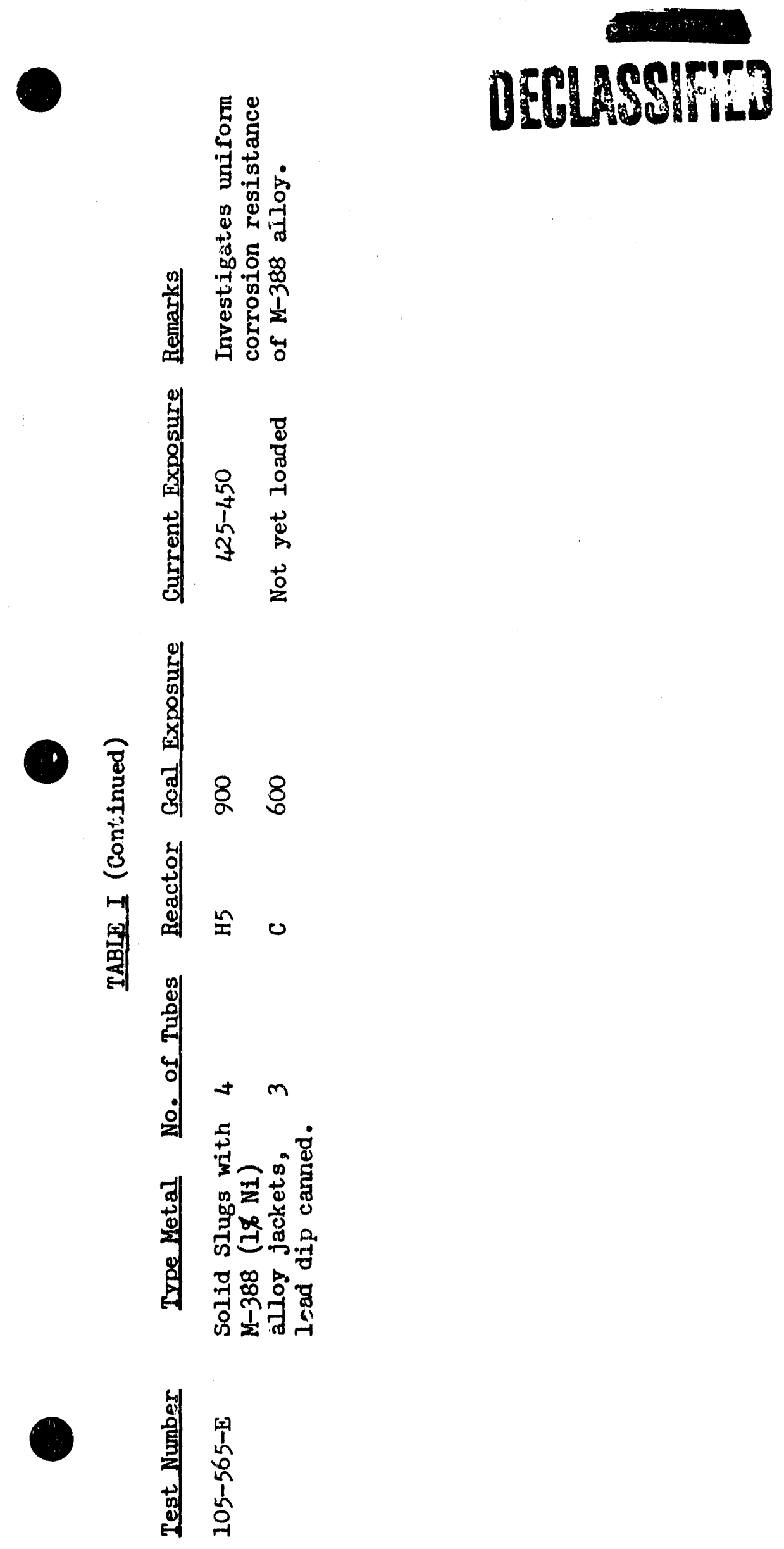

HW-476150E: 


\section{BDACTOR PHYSICS}

\section{Lattice Measurements}

Experiments to determine resonance escape probability ( $P$ ), thermal utilization $(f)$, and fast effect (E) for a seven element cluster lattice were performed in the Physical Constants Testing Reactor. Results from these experiments as well as results from previous measurements of these parameters in solid slug and cosed slug fueled lattices are still undergoing analysis. This work was done with an 8-3/8 inch graphite lattice containing a process tube with a nominal 2.0 inch I.D.

\section{Analrtical Lattice Phrsics}

The $P_{3}$ approximation to the solution to the transport theory relationships has been used in computing thermal flux distributions in numerous lattice arrangements. Disadvantage factors, i.e., ratio of thermal flux incident at slug surface to the volume averaged, were calculated assuming neutron energy spectra corresponding to thermal equilibrium about $20^{\circ} \mathrm{C}$ and $120^{\circ} \mathrm{C}$ temperatures with the following results:

TABLE II

\section{CALCULATED AND EXPERTMENTAL DISADVANTAGE FACTORS}

\begin{tabular}{|c|c|c|c|}
\hline \multirow[b]{2}{*}{ Slug Trpe } & \multicolumn{3}{|c|}{ Disadvantage Factors } \\
\hline & $\mathrm{P}_{3}\left(20^{\circ} \mathrm{C}\right)$ & Experimental & $P_{3}\left(120^{\circ} \mathrm{C}\right)$ \\
\hline I.68" O.D. Solid & 1.404 & 1.385 & 1.339 \\
\hline 1.68" O.D. $-0.5 n$ I.D. & 1.324 & 1.301 & 1.272 \\
\hline 1.93" O.D. Solid & 1.506 & 1.447 & 1.426 \\
\hline
\end{tabular}

Work is proceeding on the detailed calculation of the spatial distribution of neutrons in slugs using the diffusion theory, $\mathrm{P}_{3}$ method and the method of successive generations. Work is also continuing to derive a computer program which will accurately predict the physics associated with changes in existing lattices; a usable program is presently developed for solid and cored slug geometries but the I \& E slug case is not now accurately described.

\section{Analog Computer}

Process and Reactor Development personnel visited Coodyear Aircraft Corporation with Laboratory Operations personnel to observe progress and testing on the computer being fabricated for Hanford. The delivery date is quoted as 1-1-57. A program of reactor safety computations has been developed, described in terms of the electronic analogues and will be the first large-scale study undertaken by the coinputer. 


\section{Nuclear Safety}

The review of nuclear hazards associated with the higher power level operations of those reactors affected by projects $C G-558$ and 600 was documented as HN-47708, "Hazards Summary Report - Projects CG-558 and CG-600 - Reactor Plant Modifications," R. E. Trumble.

\section{E-N Load}

The enriched metal loading to evaluate E-slug stability and the in-pile conversion ratio for tritium and plutonium production associated with the E-N loading was accomplished at B-Pile. Two twelve-tube blocks were loaded one with solid E-metal slugs (uranium enriched to 0.94 weight percent U-235) and one with half-inch cored E-metal slugs.

\section{REACTOR ENGINEERING}

Mechanical

A tentative design for Tru-line slugs was developed jointly with Facilities Engineering personriel. Test quantities of the revised design have been ordered for cocking and colum bowing tests to be performed by Facilities Engineering.

Under certain conditions it is possible for nozzle misalignment to contribute to slug cocking during the normal charging operation. A program was negotiated with Facilities Engineering to evaluate the significance of this effect through flow lab tests.

Contributions have been made to the Engineering Standards group activities in the Mechanical Standards area as requested.

\section{Adequacy of Cooling}

Numerous measurements of the conditions under which cavitation would be experienced in the double orifice assemblies in the reactor fringes have been completed by Laboratory personnel. The data have been evaluated in terms of conditions existing and expected to exist at the reactors and recommendations made to improve conditions where the margin of safety is deemed insufficient. The problem is essentially that of ensuring that the cavitating point is sufficiently removed from the conditions experienced during operation to permit the Panellit protection to remain fully effective.

Numerous tests conducted on the CG-558 water plant at B-Pile have been conducted and the results evaluated. They are being reported in detail in a report now in preparation.

\section{Process Improvement Program}

The draft of a process improvement program which schedules and defines incentives for major activities in the Category I Research and Development program and the Process Technology development program has been prepared in: cooperation with the Operational Physics and Process Technology Operations. 
The Category I Fuel Element Development and Irradiation Testing program for the remainder of FY-57 has been prepared jointly with the Laboratory Operation and Fuel Preparation Department personnel.

\section{Production Tests}

Production tests which were active prior to September 1 in the graphite, materials, water quality, and corrosion development areas have been evaluated as to need and justiflication for continuance. Those which merit continuance have teen redesignated as "IP" tests with appropriate changes in procedures, responsibility, and cost coding incorporated.

\section{ADVANCED PLANNTNG}

Combined Operations

The generation of information regarding the HAPO operation has proceeded on the schedule developed by the Combined Operations Working Conmittee. This group, which includes representation from AEC, Savannah River, and ORNL, is addressing the problem of determination of optimum $g / T$ operation at the reactor sites. Information and cost data scheduled to be developed and submitted by other sites have not arrived on schedule so the complete HAPO analyses may be delayed. Fuels Preparation and Chemical Processing Department personnel are cooperating with IPD in providing data for this study.

\section{Process Studies}

Rather detailed evaluations of the incentives for adjusting $g / T$ levels at HAPO under ranges of reactor operating conditions as programed for the future are well advanced. The major uncertainties are in the scheduling of improved fuel performance and in the cost structure of metal fabrication plant operations. Generally, these studies bear out previous work showing that under rupture limitations low goal exposures are economically preferred while there is some economic incentive for raising exposure levels, at the cost of production, when fuel performance permits full utilization of the reactor cooling capacity in effectively "rupture-free" operation.

\section{Adranced Reactor Studies}

Preliminary technical criteria have been developed for a graphite morierated, organic cooled reactor. These criteria will be used in joint studies by Research and Engineering and Facilities Engineering personnel to arrive at a preliminary reactor plant design and evaluation of associated costs and incentives. 


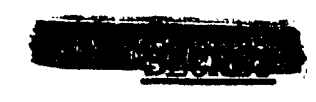

$\mathrm{HW}-47615$

\section{RADIOLOGICAL FNGTNEERTNG}

\section{Radiation Control Experience}

A radiation occurrence on December 28 at the KW-Reactor Involved a lacalized over-exposure to a Process Operator. The Operator held a hose nozzle in this hand for about five minutes while he attempted to decontaminate a grating at the storage area viewing pit. A radioactive particle lodged on the nozzle contributed to a dose rate of $100 \mathrm{rads} / \mathrm{hr}$ at surface uncorrected for source size as read with a CP meter. Film studies indicated a maximum dóse of 150 rads including $2 x$ to one square centimeter of skin area through a plastic glove. Formal investigation by committee action is pending.

IAPSE OF RADIATION CONTRUL DISTRIBUTION BY REACTOR AND OPERATION

Processing

Maintenance

Supplemental Crews

Radiation Monitoring

Central Maintenance

IPD - Unassigned

Totals

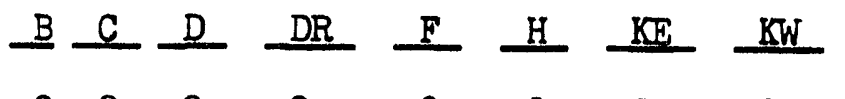

$\begin{array}{llllllll}2 & 0 & 0 & 0 & 0 & 0 & 2 & 2\end{array}$

$\begin{array}{llllllll}0 & 1 & 0 & 0 & 1 & 0 & 2 & 0\end{array}$

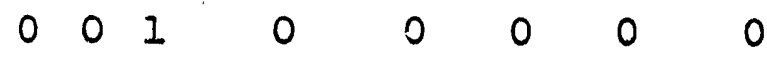

$\begin{array}{llllllll}0 & 0 & 0 & 0 & 1 & 0 & 0 & 0\end{array}$

$\begin{array}{llllllll}0 & 0 & 0 & 0 & 0 & 1 & 0 & 0\end{array}$

1010101

$312003 * 1153$

1

1
IPD Total

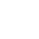

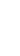

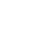

Other than IPD

* In the case of F-Reactor, one lapse of control was chargeable to two components.

There were 18 Reports of Lapse of Radiation Control issued during the month of December. Seventeen of these were the responsibility of Irradiation Processing Department. Spread of contamination to skin, clothing, or normally non= contaminated areas was the cause of 13 of these Lapse of Controls. Skin contamination occurred in three cases, personal alothing contamination occurred in four cases, and six involved the spread of contamination to normally noncontaminated areas. There were three cases of uncontrolled exposure of personnel to radiation, and one case of failure to wear personnel meters.

The one Lapse of Control which was not the responsibility of the Irradiation Processing Department is of interest. A Maintenance employee received an estimated dose to the skin of his right index finger of 1000 mrads when he wore an intermally contaminated glove. The glove was internally contaminated when received from the plant laundry. Subsequent surveys of clean laundry in the storage bins revealed other gloves contaminated up to $80 \mathrm{mrads} / \mathrm{hr}$ at surface.

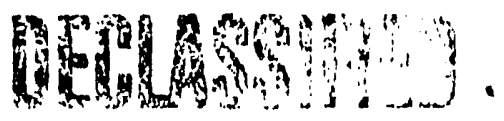


Disinussions were held with representatives of Chemical Processing Department and Hanford Laboratories Operation representatives concerning the classification of potential over-exposure incidents. This statistic is desired by HIO for reporting purposes, and for comparison with previous figures, it is desired to judge these incidents on the same basis as in the past. This is tentatirely interpreted to mean that a potential over-exposure incident has occurred when actual over-exposure was narrowly averted, such as by accident or by chance. On this basis, there were four potential over-exposure incidents in IPD during September, three during October, none during November, and one during December.

\section{Radiation Control Standards and Procedures}

Twenty-three Radiation Control Standards are circulating for acceptance signature and several others are in draft form. Six Radiation Control Procedures have been prepared for comment.

\section{Reactor Wastes and Effluents}

Joint activities with Laboratory personnel are directed to define a sound scope for the effluent water activity monitoring program. The objective of this activity is the definition of those tests which will provide 1) adequate information regarding the radioisotopes being discharged to the river, 2) permit the isolation of the source of these activities and their dependence upon reactor operating variables, and 3) efficiently utilize manpower, money, and facilities devoted to the monitoring effort.

Substantial increases in the activity on the 183 process water filter beds was noted in November at $\mathrm{D}, \mathrm{H}$, and $\mathrm{F}$ Areas. In conjunction with this a marked increase in drinking water activity was also noted although the activity is still less than one percent of permissible concentrations. The source of this increase is being investigated and may be due to malfunction of the $K$ outfall lines to the river.

\section{Protective Clothing.}

The protective clothing committee met to evaluate mask and boot designs. Field testing programs were initiated as were design changes.

\section{Projects}

Radiological Engineering study and review was given numerous projects or budget items in the FY-57, 58, and 59 budgets. Definitive conclusions were reached on the following major items: Reactor Building Exhaust Stack Filters, Inland Lake Canal System, Reactor Shield Patching, Radiochemical Laboratory, and $\mathrm{K}$ Out fall Iine Replacement; these conclusions will be Independently documented in detail.

\section{Iraining}

Radiological Engineering contributed to the IPD Radiation Monitor Trainee school and particjpated in the planning of a course for Radiation Monitors in the GE School of Nuclear Engineering.

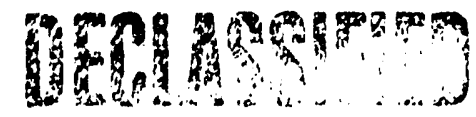




\section{PROCESS TECHNOLOGY OPERATION}

POWER LEVEL LIMITATIONS

Pile power levels have been limited during December 1956 as follows:

Pile

B

C $970 \mathrm{KW}$ max. tube power ${ }^{2)}$

D

$\mathrm{DR}$

F

$\mathrm{H}$

$\mathrm{KE}$

KW

$\underline{\text { Limit }}$

$850 \mathrm{KW} \max$. tube power ${ }^{1}$ )

$105 \mathrm{C}$ max. tube outlet

$105 \mathrm{C} \max$. tube outlet

102 C max. tube outlet

$105 \mathrm{C} \max$. tube outlet

$1125 \mathrm{KW}$ max. tube power

$1125 \mathrm{KW} \max$. tube power
Basis

Slug rupture considerations planned rise program.

Slug rupture considerations

$\begin{array}{lll}n & n & n \\ n & n & n \\ n & n & n\end{array}$

Slug rupture considerations planned rise program.

Slug rupture considerations planned rise program.

1) $\mathrm{B}$ Pile resumed operations after CG-558 modifications on 12-8-56.

2) The maximum tube power limit was reduced to $920 \mathrm{KW}$ near the end of the month to reduce rupture frequency.

\section{GENERAL PROCESS ENGTNEERING}

\section{CG-558-B}

Shift coverage by Process Engineers was provided at B Pile three days prior and two days after the startup from the Project CG-558 shutdown. Except for the occurrence of high outlet temperatures in the outermost fringe zone which can be eliminated by orifice changes, no operating problems of great importance a ssociated with the modifications have arisen. Maximum tube power is being limited to $850 \mathrm{KW}$ as the first step in determining the slug rupture limit. At present, total pile flow is $69,000 \mathrm{GPM}$, whth an average central zone tube flow of 39.2 GPM at a top-of-riser pressare of 523 psig.

\section{CG-558 - General}

Preparations for the forthcoming CG-558 outages at DR, D, F and H Piles have continued. The procedures for valving during shutdown, Panellit checks, and operation of the revised Panellit system have been completed for DR Pile. Writing of similar procedures is underway at $D, F$ and $H$ Pliles. 


\section{Prediction of Startup Panellit Pressures}

Changes of process tube loadings, inlet fittings or the process tubes themselves during reactor shutdowns cause a change in the operating Panellit pressure such that in many cases range changes of a large number of Panellit gauges is required before operation may be resumed. Current practice is to make the required range changes after raising water pressure preparatory to startup. This method allows a more precise determination of the required range change but delays startmup of the reactor from two to four hours in many cases. A study is being conducted by the Process Engineer at $\mathrm{H} P$ ile to determine methods of predicting the required range changes. It is estimated that two hours of shutdown time were saved by predictions made for the H Pile outage of December 2, 1956 .

\section{Critical Flow and Cavitation in Inlet Fittings}

Application of data recently obtained from the Thermal Hydraulics Operation concerning cavitation and critical flow in the inlet fittings has been made to the piles. Various programs for alleriating possible cavitation conditions at concerned piles have been developed and are underway.

\section{K Pile Pump Cavitation}

The test to determine the feasibility of operating the $K$ Area high lift pumps at full speed, thereby increasing pile flow, was started in December. After several months of operation under these conditions, the pump being tested will be disassembled to inspect the impeller for evidence of cavitation effects.

\section{WATER TREATMENT}

A seasonally unusual increase in the turbidity of the river water caused some difficulty with water treatment during the month. A minimum of difficulty was encountered in the areas having Separan feed facilities. At the $K$ Areas where Separan feed facilities were not complete, there was a sharp increase in the turbidity of the filtered water until a temporary method of feeding Separan was devised by Power Personnel. After the start of Separan feed there was no further difficulty with process water quality. The 100-F Area personnel maintained control of process water quality by the use of activated silica. The 183-B Area operated satisfactorily at CG-558 flow rates during the tur bidity period. Filter runs were 8 hours or longer except for a short period when Separan feed was too low. Water quality was excellent.

\section{PROCESS STANDARDS}

$\mathrm{HW}-46000 \mathrm{~B}$

The new Process Standard - Reactor manual, HW- $46000 \mathrm{~B}$, was issued on November 27. The new manual provides post CGo558 Iimits for tile B and C Reactor Operation only and supersedes HW-33000 at these reactors.

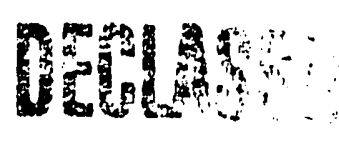




\section{HW-33000}

Two revisions to Process Standards - Reactor, HW-33000, were issued during the month. These were:

Process Standard C-110 - "Inoperable Rods and Hoppers During Shutduan"

A section was added permitting VSR's to be held out of the reactor under certain conditions during brief "planned" outages, such as "quickies" or poison pushes. This will improve the chances of resuming operation within the scram recovery time.

Process Standard A-050 - Water Pressure - Flow During Reactor Shutdown"

Three new water shut-off curves which apply to process tubes during reactor shutdown were added to the present Standard. The curves for crossheaders present new information. The curve for single tubes present previous water shutoff data in a more convenient form.

Two new Standards were added to the manual to cover initial operation of the KER in-pile loop. These were:

Process Standard $K-010$ - "General Requirements"

Specifications were provided to control the integrity of in-pile recirculation loop components.

Process Standard $\mathrm{K}-020$, - nOperation Without Fissionable Materialn

Provides limits covering initial operation of the KER Recirculation Facility with non-fissionable charges only.

HW-27155 Rev.

Copies of new Water Plant Standards were issued to the B - C Reactor Operation during the month. These Standards incorporate post $C G-558$ and $C G-600$ operating limits.

\section{Process Change Authorizations}

Nine Process Change Authorizations were issued to permit temporary relaxation of the Process Standards - Reactor, HW-33000 and HW-46000 B.

\section{PCA \#146- morizontal Rod Insertion Speed - F Reactorn.}

HCR scram insertions at $F$ Reactor took as long as 95 seconds, as compared to the specified maximum of 90 seconds. This PCA authorized HCR scram insertion times up to 120 seconds since the VSR'g are the principal control for emergency shutdown and the only requirement for HCR's is that they be completely in the reactor before start-up is attempted. 
PCA \#147 - "Water Pressure Trips - B Reactorn

The new Process Standards manual HW-46000 B, necessarily contained pre-CG-558 water pressure trip settings when initially issued. This PCA specified new values for the riser pressure and Ball 3X trips at $B$ Reactor based on values determined during the November 29 trip-out tests in that area.

PCA \#148 - "Enriched Slug Shipment - KE-KW Reactors"

$\mathrm{K}$ Reactors were authorized to prepare off-site shipments of enriched material provided the provisions of Standard $\mathrm{H}-\mathrm{O}_{2} \mathrm{O}$ were followed. Shipment had been confined to $\mathrm{C}, \mathrm{H}$ and $\mathrm{DR}$ Reactors because, previously, special handling equipment was available only in these areas.

\section{PCA \#149 - "Cross-Under Line Operation - K Reactors"}

This PCA authorized use of the crossmunder line at the $K$ Reactors for chargedischarge purposes, although the 105 crossmtie line was out of service at the time to permit examination of the $K E \nabla-73$ valve. The use of a special procedure provided by the PCA permitted this to be safely done.

PCA \#150 - Water Pressure Trips - B Reactor"

Based on later tests, this PCA specified new water pressure trips superseding those in PCA \#147. The new trip settings reduce the possibility of an inadvertent ball drop after a BPA failure without compromising reactor safety.

PCA \#151 - "Rear Dummy Charge - KE Reactor"

This PCA authorized changing the rear dumny charge in four selected tubes to investigate the feasibility of this method of raising back pressure in double orifice tubes.

PCA \#152 - "Graphite Temperature Limits - KW Reactor"

This PCA authorized lowering of graphite temperatures below the specified minimum in order to compensate for long term reactivity gains until flattening adjustments could be made during the next scheduled outage. No adverse effect on reactor life is expected because of the short duration (5 days) of this method of reactivity control.

PCA \#153 - mPCC Tube Dumy Charges - B Reactor"

This PCA authorized shorter charges in PCC tubes than those necessary to prevent cavitation. This was necessary in order to obtain the desired flexibility in the use of this facility. This action is only permitted with non-heat generating charges.

\section{PCA \#154 - "HCR WIthdrawal - D-DR Reactors"}

The Standard revision that authorizes use of new rod calibration data was circulating among the several plants for authorization signatures. Use of the new data by $D$ and DR Processing Operation was authorized by this PCA until such a time as the new Standard is signed and issued. 
RUPTURE EXPERIENCTE

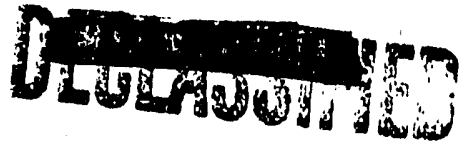

$H W-47615$

\section{Ruptured Slug Tabulation - December, 1956}

Ruptures occurred in fifteen charges during December. Fourteen of the ruptures were eight-inch regular metal, and included one regular metal failure in a C-metal (U-235 Al Alloy) column. One dingot material slug (PT 105-608-A-56MT, Supplement A) failed at $C$ Reactor. Pertinent data are tabulated below:

\begin{tabular}{|c|c|c|c|c|c|}
\hline Failure Date & Tube No. & Lot No. & Type Metal & Exposure & Type Failure \\
\hline $11-29-56$ & $0468-C *$ & $C-14$ & C-Metal & $\begin{array}{l}37.9 \% \\
-235 \text { Depletion }\end{array}$ & Side Chatter \\
\hline $12-2-56$ & 1078-H & $\mathrm{K}-290$ & 8n Reg。 & 761 & Side H.S. \\
\hline $12-2-56$ & $2991-\mathrm{H}$ & $Y-22$ & $8^{n} \operatorname{Reg}$. & 239 & Cap \\
\hline $12-5-56$ & $3654-K E$ & $K-384$ & $8^{n} \operatorname{Reg}$. & 422 & N.A. \\
\hline $12-7-56$ & 2576 anctx-4 & $V-64$ & gn Dingot & 356 & Split I. \\
\hline $12-9-56$ & $2878-C$ & $Y-35$ & gn Reg. & 373 & Side H.S. \\
\hline $12-13-56$ & 3279-D & $K-315$ & 8n Reg. & 705 & Side - Other \\
\hline $12-17-56$ & $2584-C$ & $z-223$ & 8n Reprocessed & 146 & Side H.S. \\
\hline $12-18-56$ & 0777-KW & $\mathrm{K}-201$ & gn Reg. & $* * *-*$ & Unclass. \\
\hline $12-20-56$ & $3181-K W$ & $z-196$ & 8n Reprocessed & 408 & Unclass. \\
\hline $12-20-56$ & $2482-C$ & $M-213$ & gn Reg. & 349 & Unclass. \\
\hline $1.2-21-56$ & $2176-C$ & $z-232$ & 8n Reprocessed & 150 & $\mathrm{~N} \cdot \mathrm{A}$. \\
\hline $12-23-56$ & $2469-\mathrm{H}$ & $\mathrm{K}-342$ & 8n Reg. & 587 & Side - Other \\
\hline $12-25-56$ & $1478-\mathrm{H}$ & $M-167$ & 8n Reg. & 565 & Unclass. \\
\hline $12-25-56$ & $3085-\mathrm{H}$ & M-197 & 8n Reg. & N.A. & Side - Other \\
\hline $12-31-56$ & $4263-F$ & $\mathrm{~K}-354$ & gn Reg. & $\mathbf{N} \cdot \mathbf{A}$. & N.A. \\
\hline
\end{tabular}

* Previously unreported. Tube contained three ruptures.

* Rupture caused post-discharge operational diffleulties due to gas evol-ation. Rupture is being examined by Radiometallurgy Operation.

in-* Irradiated under PT 105-608-A-56MT, Supplement A.

* * Tube contained 36 C-metal pieces and six regular metal pieces. A regular metal piece failed. The depletion of $0-235$ in the C-metal was 45 per cent. 


\section{Legend:}

$\begin{array}{lll}\text { N. A. } & - & \begin{array}{l}\text { Information not available. } \\ \text { Side H.S. }\end{array} \\ \text { Side - Other } & - & \begin{array}{l}\text { Failure probably caused by local overheating (hot spot) } \\ \text { possibly intergranular corrosion. }\end{array} \\ \text { Split } & - & \begin{array}{l}\text { Failure probably caused by a localized corrosion } \\ \text { penetration, e.g. pin hole penetration, or other unicnown } \\ \text { mechanism. }\end{array} \\ \text { Cap } & - & \text { Slug split longitudinally, diagonally, or transversely. } \\ \text { Unclassified } & - & \text { Failure caused by loss of cap or penetration at the cap. } \\ \text { Side thatter } & - & \begin{array}{l}\text { Failure type does not fit into any particular category. } \\ \text { due to slug vibration or chattier. }\end{array}\end{array}$


During the December 8 B-P1le start-up following the CG-558 cutage, the neutron level was monitored throughout the approach to critical and until the pile instrumentation gave meaningful readings with a supplementery proportional counter temporarily installed in the A test hole. The cold reactivity was 110 Inhours less than predicted; however, the hot reactivity status was as expected. The error was caused by the lack of data in the low exposure renge of the Braphlte temperature coefficlent of reactivity as a function of in-p1le exposure. The flattening at equilibrium vas better then the preceeding 12-month average in spite of the loss of reactivity assoclated with the reduction in in-pile exposure. Current discharge plans will reduce the in-pile exposure further, causing a hot-plle reactivity 1083 of 160 inhours; the plle will be operated during the next month with essentlally no excess reactivity invested in plattening.

The K-P1les showed further flattening improvements of 2 - $3 \%$ as shown by increased effective central tube values. All other plles showed decreases of 1 - 3\%; however, all except $\mathrm{B}-\mathrm{p} 1 \mathrm{ll}$ were above the 12 month everages.

Table I sumarizes the pertinent operationel physics information of the various plles; a more detalled status report is given in the monthly" "Reactivity Balence and Assoclated Data" document.

A supplement to the $81 x$-year summary of reactivity and operating data(I) has been started. It w1Il add the information made avallable in 1956 and w1ll be 18sued early in 1957.

A revised shutdom data sheet form is in preperation; it will be adopted as of 1-1-57. Also beglnning on 1-1-57, there w1ll be a mester copy of all shutdown data sheets arallable at 300 Files.

B P1le: J. T. Worthington and I. B. Ufkes

Operation was resumed at B P1le on December 8, following the completion of the CG-558 modiflcat10ns. There was a -110 inhour discrepency between the cold clean reactivity and thet predieted using the $C_{g}$ VB. F equation published in the Oetober Monthly Report. A better eraluation of $\mathrm{Cg}$, as a function of in-pile exposure, w1Il be made as data become avallable. The pile was operated at 850 kw nominal tube limit with no llattening other than 10 PCCF tubes loaded with aluminum and 9 with water only; there was en excess of 275 in in control rods under the revised calibration with $50 \%$ delium in the reactor atmosphere.

At the inst1gat 1on of the P1le Phys1cs Operat1on the Instrument Development Group installed a supplementary proportional counter in the A-test hole fac1lity for this initial start-up. Chenges in background were seen throughout the approach to critisal:

(1) EN-41488, React171ty Trends and Pred1ct10n Problems Versus Operating Trends, 1950 - 1955, March 20, 1956, R. 0. Brysga. 
TABIRE I

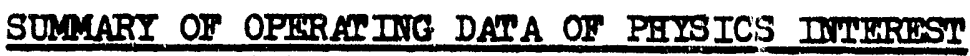

FOR THE DECEHRER RHPORI PMRIOD

PITE

B

C

D

DR $\quad$ F $\quad$ H

KIE

W

$\begin{array}{lllllllll}\text { E.C.T. Dec.* } & 1345 & 1580 & 1405 & 1430 & 1340 & 1520 & 2370 & 2490\end{array}$

12 Nonth

$\begin{array}{lllllllll}\text { Aug. B.C.T. } & 1280 & 1580 & 1390 & 1420 & +320 & 1550 & 2320 & 2350\end{array}$

Equilib.

Scran Timo in

Minutes**

20

25-35

$35-50$

$30-45 \quad 50-55$

$75 \quad 26-29$

$25-30$

Io. of Sctams** 3

and Recoverles

$3 \quad 30$

2

111

3

3

0

Ho. of Iron-Scram Outages

$1 * * * 11$

2

0

1

2

1

3

* Iffective Contral Tubes; this value is defined as the pile power divided by the average power of the ten most productive tubes.

* Defined as the maximum time in minutes available between scram and the first indication of a successtul start-up.

* Includes all instantaneous shutdowns, equilibrlum and non-equilibrium, and "quickie" outage shutdown from equilibrium following whlch recoveries wore attempted.

*** Th1s was the outage to d1scharge polson; the CG-558 outage wh1ch lasted 1nto December was not included. 
B Pile: J.T. Worthington and I. B. Ufkes (cont.)

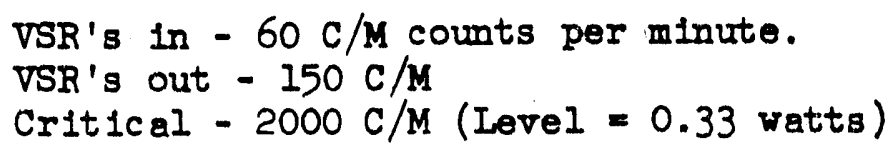

The standard instrumentation was checked for sensitivity after the supplomentary P. C. was removed; approrimate sensitivities were as follows:

$\begin{array}{lr}\text { \#2 Beckmen (GE Mark II chember) } & 12 \text { watts } \\ \text { Regular P. C. } & 50 \text { watts } \\ \text { \#I Galvanometer } & 120 \text { watts }\end{array}$

The under-pile PC at $B$ PIle is less sensitive then the P. C.'s at other plles because there is more lead between the plle and the chamber.

Porty-five tons of $550 \mathrm{MWD} / \mathrm{T}$ average concentration materlal are scheduled to be discharged on December 26. This will cause a loss in cold clean reactivity of 17 inhours and a 1038 in hot reactivity of 160 inhours. Minimum control rod requirements are about 275 inhours. In order to supply this excess in rods, all but four of the PCCF tubes will be charged with urenium during the next start-up.

Two blocks of 12 tubes each are to be cherged with $\mathrm{E}-\mathrm{N}$ materlal under PI-IP-2A this out age; 24 surrounding tubes will be charged with green uranium in each case. No unusual temperature or reactivity effects are expected.

C P1le: F.C. Pranklin

There were flve shutdowns at C P1le for ruptures in production uremium during December; a tube water leak was assoclated with one, but the reactivity epfects were small. The operating tube power limit was reduced from 970 to 920 wH to reduce the rupture rate.

Fifty tubes were charged with I \& IE slugs this month bringing the total number of I \& $\mathrm{E}$ charges in the reactor to 105, plus one onrlched I \& $\mathrm{I}$ chargo. Twenty-two of the I \& $\mathrm{E}$ tubes contain full length charges.

During the 12-17-56 outage the counting rate on the hot-start-up PC system was found to be quite high. A check of the system indicated that the source of the trouble was the PC chember. The chember was removed and a new chember was ordered. The chember showed no slgns of falling the last time it was used. The chamber had been in use for about one year.

D P1le: G. R. Gellagher (for G. R. Parkos on Vacation)

The change to the new control rod values and the assoclated coefficlents was mede th1s month. Non-equilibrlum screm-recovery curves have been prepered, but their use will be deleyed until all personnel have been instructed in their use.

A vater leak in tube 3279 on 12-21-56 caused a cold plopeactivity loss of 75-100 inhours. There vere no unusual operating deffickitfos during the dry ingout period. 
DR P1le: D. E. Goins

The plle has been operated for more than one month without an outage for charge-discharge or flattening changes. The operating perlod began with no Plattening in the Polson Colum Control Facility, making it necessary to use a different control rod configuration than in the past to prevent front-torear cycling of the power distribution.

The long reactor operating period during December resulted in a reactivity gain of approximatels 100 inhours. Primary compensation for this gain, assoclated with residual plutonium bulldup, was flattenlng charged in the Polson Colum Control Fac1lity. The offective central tube value was meintained essentially constent in spite of the reactirity change.

During a scram recovery a potentially unsafe condition existed whon a misinterpretation of the base reactivity point on the scram recovery chart resulted in an attempt to withdraw the horizontal control rods considerably beyond critical. A rising period wes observed on the PC during the HCR withdrawal sequence, and further withdrawals were stopped until the magnitude of the rising period was determined to be 60 seconds. The misinterpretation was immedlately apparent, and the subsequent start-up was effected in accordance with prescribed procedures. This incident emphasizes the continuing need for operator training and for moro sensitive start-up instrument at 1on.

F P1le: D. E. Simpson

The meximum power level attained was $55 \mathrm{MN}$ higher than that reached during the operating period covered by the November monthly report. Approximately $20 \mathrm{MN}$ of the increasis in the maximum power level was due to exceeding the arbitrary temperature limlts due to mal-calibration of the temperature monitor; the rest was due to the seasonal decresse in inlet water temperatures.

The proportional counter was checked during reactor operation and appeared to be in proper working condition; however, it falled to operate satisfactorlly at any time during the scram transient test of Decomber 14. During the following outage the equipment was thoroughly inspected, a vacuum tube in the scaler was replaced and the chamber plateaus were re-measured. The instrument functioned satisfactorily on the subsequent start-ups.

The No. 3 Beckman was replaced with a modified instrument which extends the range and permits scale changes by less than a factor of ton. No. 3 and No.4 Beckmens now have this modification and both are equipped with mechanical stops to prevent inadrertant switching to a less sensitive range when operating at or near equilibrium power levels.

\section{P1le: I Murakam1}

Operating continuity during the roport period was interrupted by two scrams, one shutdown for the successiul quickie discharge of a ruptured slug, one scheduled outage for process tube replacement, and one unscheduled out age.

A new type Brown temperature recorder and corresponding instrument clrcultry for the elexowriter tube temperature monltor were installed. The new system allows the typewriter to print three-digit numbers as compared to the old one which was Ilmited to two dig1ts. Minor adjustments are occasionalis required as yet. 
KI P1le: W. S. Nechodom

The reactor was scramed from equilibrium on December 5, by a high panellit trip on tube $3654 \mathrm{KE}$ which was subsequent ly found to contain a rupture. The scram occurred while rupture indications were being invest igated, hence recovery was not attempted. The reactor was shut down on December 11, for tie-in of the KERR facility. This outage continued unt1l December 21.

A Scram Transient Test was performed after the shutdown on December 11. Difficulty in withdrawing VSR's delayed the test so that initial data were not obtalned unt1I 28 minutes after half-down time. The data obtained Indicate that a shorter graphite cooling perlod should be used to calculate the transient. The data also suggest that a large calibration error may exist in the final portion of HCR's to be withdrawn from the pile with the error diminishing rapidiy as rods are inserted. Not enough data vere obtalned to warrant correcting the calibrations; however, further data should be obtained to determine the magnitude of this error.

\section{EW Pile: R. D. Carter}

A new meximum equilibrlum power level $35 \mathrm{MW}$ above the previous high for a reactor was reached during the month. Th1s resulted from increased flattening efficlency brought about by higher fringe reactivity.

On December 18, a regular motal plece on the upstream end of an enrichment colum ruptured in tube $0777-\mathrm{KW}$. Th1s column was originally charged September 18, 1955 and was at about $46 \%$ burnout of the U-235. It had not been discharged because of flattening ond replacement conslderations. At the tIme of rupture the slue exposure was about $1250 \mathrm{MND} / \mathrm{s}$ besed on a cosine flux distribution; flux distortions due to nearby control rods probably caused the actual value to be somewhat lower. The tube was operating at approximately $700 \mathrm{KW}$. 


\section{WES MENAED}

$\therefore+1,1,+\infty$

\section{PROCHSS PHYSICS STUDIHS - OPHRAPIOHAL PHYSICS OPHERAYION}

\section{Operating Efficlency Data}

Potential gains from improved flattening and rod control obtained from temperature map studies vere nearly $2 \%$ greater during December than November; this increase is approrimately the seme as the average reduction in effective central tubes. The above observations indicate that the 8 ame average levels were attainable in December as in November provided that adequate flattening and rod control technlques had been arailable and efficlently employed in both cases; supplementary control would be required if varlations in potentlal equilibrium gains of this order of magnitude wero to be arolded. Non-equilibrium operating $1088 e s$ in December were approx1mately the same as in November. The report perlod covered in the following table will henceforth extend from the 15th of one month to the 15th of the next. Because of this more exactly defined report period, some of the nonequilibrlum numbers may reflect potential gains also reported last month.

\section{POTHWNIAL GATNS - OPHRATIONAL PHYSICS ASPECTS}

Reactor

Equilibrium Potential
Bl C

$\begin{array}{rrr}7.2 & 1.0 & 2.1 \\ 3.7 & 1.2 & 1.7 \\ 10.9 & 2.2 & 3.8\end{array}$

D DR

F $\quad$ H

KEE INW Average

Flattening ${ }^{2}$

Rod Control 3

Total, Existing Iimits

$\begin{array}{llllllll}7.7 & 4.7 & 5.4 & 3.2 & 3.3 & 3.4 & 5.2 & 4.7 \\ 0.5 & 0.9 & 0.0 & 0.6 & 1.6 & 1.0 & 0.5 & 0.7 \\ 8.2 & 5.6 & 5.4 & 3.8 & 4.9 & 4.4 & 5.3 & 5.4\end{array}$

Non-Equ11. Potent1al

Operating Losses ${ }^{4}$

Temporary "P" Outages

Total, Start-Up Control

$8.2 \quad 5.6 \quad 5.4$

8.1

$7.9 \quad 3.9$

2.24 .1

$10.3 \quad 12.0$

3.9
0.0

2.6

4.7

$1.8 \quad 2.1$

$\begin{array}{lll}3.9 & 4.4 & 6.8\end{array}$

1. B Plle did not have sufficlent operating experlence following the CG-558 outage and prior to 12-15-56 to determine significant efficiency data.

2. Percent to be gained if desired flattening changes could be made.

3. Percent to be gained by having most limiting tube under influence of each rod tip at limits.

4. Percent of non-equilibrium losses relative to 30 days at full level.

I P1le Horizontal Rod Calibration

Present schedulfing calls for carrying out the low-level perlod calibration of the H pile system during the first out age in January, 1957. Because of the large discharge scheduled for this outage, the test has been modifled slightly to Include charge discharge after completion of the test. Several meetings have been held to aqualnt both Operational Physics and H p1le operating personnel with the test aims and procedures.

Start-Up Accident Calculations

The problem of establishing the rate of power rise as a function of rod withdrawal rate has been set up on the IBM 650 computer for en equation of the form: 
Start-Up Accldent Calculations (Cont Inued)

$$
\frac{d^{2}(f l u x)}{d t^{2}}+(A t+B) \frac{d(f l u x)}{d t}+(C t+D)(f l u x)=0
$$

Values for the flux and its time derivative were obtalned at half second Intervals for a time range of 50 seconds, assuming a single delajed neutron group to be representative, for the remote case of obtaining criticality during VSR withdrawal. Results indicate that with a continuing rod withdrawal rate of 10 ih per second, and with normal cold start-up trip settings in force, the maximum level reached before the VSR's shut off the excursion would be approximately the normal operating level. The power generated in such a short rise would not be sufficlent to cause bolling under full flow conditions even though the peak excess reactivity condition exceeds the minimum prompt critical value. These results indicate that the present process standard limits on VSR withdrawal rates for cold start-ups are safe.

This type solution w11l be applied next to the case of hot start-up approaches to critical assuming reactivity addition rates from $10 \mathrm{ih} /$ minute up to the mechenical HCR withdrawal speed. Final checks will be made on the analogue computer to test the accuracy of results based on simplified assumptions.

\section{Nuclear Sefety Studies}

The study of plle safety consldering unbalanced enrlchmont is continuing. Flur-matching calculations indicate the loading which is more unbalenced that at other reactors to meet the basis for the present process standards. In general, the total emount of permissible enrichment investment must be roduced as it is loaded in on unbalanced array.

In the course of preparing for test plie experiments to compare ball channel vs. VSR effectiveness, it was discovered that the compositions of $H$ and IR PIle vertical rods are not well known. Prints indicate that an aluminum Iiner between the outer steel shell and the polyethylene interlor holds the boron pois on in place. Because of the 1mplicat1ons that with high graphlte temperatures the poison mlght tend to settle due to liner melting, further invest1gat1ve action has been initiated to insure that applicable process standards are on a flrm basis.

\section{E for C Testing}

Production Test IP-20-AC authorizing the preliminary charging of three colvme of $0.94 \%$ onrlched uranium in $\mathrm{H}$ P1J.e is presently belng clrculated for s1gnatures. Unless material already on-site but in excess for $\mathrm{s}-\mathrm{ll}$ tests 18 re-allocated by the AEC for this test, slugs w1ll not be avallable unt 11 at least the latter part of Pebruary. In tho latter case, it may be deslrable to forego this init1al 3-tube loading and proceed more rapldiy to full face replacement.

\section{Sisas Long-Term Trensient Calculations}

Recalculation of the outage react1vity transients associated with neptunium decay to plutonlum and prometheum decay to samarium for the $\mathrm{K}$ reactors indicatei errors in the existing calculations. Bocause of the compensating effects of these two translents and their relatirely smaly magnitade, the 


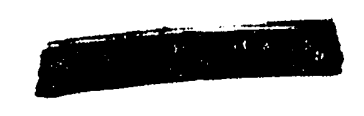

Ques1 Long-Term Trens lent Calculat1ons (Cont Inued)

errors are not severe, however. An Interesting aspect of these studies 18 the effect of speciflc power on the instantaneous pile plutonium inventory - a p1le residual with a given reactivity-wejghted exposure would show less long term gains at high specific power than at low.

\section{Shield Protection Studies}

Maximum blological shield temperatures at the B P1le during its 11rgt post CG-558 run were at or below $100^{\circ} \mathrm{C}$ in both the far side and the top. Whereas the innermost side shield ejcle is hottest, the top shield temperatures were nearly uniform through the lnner three cycles (Inner half) of the shield. This more wide-spread top shleld heating means that temperature limits for the top $\times 111$ have to be more restrictive than for the sides to permit the same rate of total shleld burmout.

A study is underway to provide the basis for setting shield temperature limits in the future. The general approach is based on the following steps;

1. From the temperature history of the shleld the burnout of hydrogen, oxygen, and carbon can be calculated.

2. Using effective remoral cross sections the increase in neutron flux penetrating the shield can be calculated.

3. The gold foll plux monitors will provide an experimental determination of the actual increase in neutron leakage.

4. Burnout constants can be adjusted to make calculated leakage rate increases agree with observations.

5. The new burnout constants based on actual shleld temperature and burnout data can be used to set shield temperature limits.

6. Sufficlent experience has been obtained with fringe polsoning plus compensating enrlchment that this method may then be used operationally to keep shield temperatures within imposed limits.

Slgnificant Operat 1onel Phys 1cs documents 1ssued during month:

1. IH-43893, "Measurement of the Control Strength of the Vert1cal Safety Systems (PInal Report, PI 105-554-A)", C. I. M1ller, 9-1-56, Secret, Formal.

2. HW-45063, "React1vity Prediction Analyses Using New Rod Calibration and Xenon Values," December 5, 1956, G. R. Parkos and R. 0. Brugge, Secret.

3. IIT-45100, "Sect1on 1100, P1le Phys 1cs Manual of Standard Pract1ces - Xenon Calculations," R. 0. Brugge, Secret.

4. HH-47119, "React1v1ty Balance and Assoclated Reactor Phys1es Data Norember, 1956," December 5, 1956, S.R. Stamp, Secret.

5. HW-47171, "Vert1cel Rods - DR and H P11es," C. L. M1Iler, 12-10-56, Secret. 
Operation through a complete cycle (Periods I through 4 ) of the water chemistry program was accomplished.

\section{RECIRCULATING GAS LOOP}

The design of the Recirculating Gas Loop proceeded satisfactorily. Inconel was selected as the material for the in-pile tube. The selection was based upon its resistance to nitriding, and its relatively favorable position regarding both the ease and available experience in fabrication. The tube will be copper plated for additional protection against nitriding.

The information which had been requested as to the work and expenditure patterns for the construction of the facility was forwarded to the AEC.

\section{ISOTOPE PRODUCTION COSTS}

A request was received from the Atomic Energy Commission that consideration be given to assessing the neutron costs associated with the production of radio1sotopes for the ORNL Isotope Program. A method for this assessment was developed and a draft of the proposal is presently being circulated for comment. The method is based upon a quantity defined as an effective megawatt day, (MWD) $E$. This quantity provides a direct relationship between the unit cost of plutonium and the loss or gain of thermal neutrons in the reactor. The (MND) $E$ of a thermal neutron absorber can be defined as the loss in MND which would result from the removal of the absorbed neutrons from a normal Hanford reactor lattice. The defining equation is:

$$
\text { (MWD } E \frac{8 f h t E}{\gamma}
$$

$q=$ Cotal number of thermal neutrons absorbed.

$f=$ Thermal utilization of normal lattice cell.

$h=$ Average number of fast neutrons emitted per capture of one thermal

neutron in a standard Hanford natural uranium slug.

$f=$ Fast effect for a standard Hanford slug.

$\gamma=$ Average number of fast neutrons emitted per fission.

$E=$ Energy release per fission in MWD.

\section{NEUTRON FLUX STUDIES}

Several rise factor measurements were completed in the Hanford Test Reactor. In this consideration, the rise factor is defined as the ratio of the volume average thermal neutron flux in the material being tested to the volume 
average thermal neutron flux in unperturbed uranium. All the materials which were tested had a standard Hanford slug diameter and were canned in aluminum. The following measuremeits were obtained with both sample material and reference uranium placed in old pile process tubing with the annulus filled vith water:

$\begin{array}{cc}\frac{\text { Material }}{10 \% \mathrm{Cd}-\mathrm{Pb} \text { alloy }} & \frac{\text { Rise-Factor }}{0.022} \\ 3-1 / 2 \% \text { II - Al alboy } & 0.80 \\ \text { Thorlum } & 1.19 \\ \text { Aluminum } & 2.66\end{array}$

A plot of the theoretical thermal blackness of a material against the product of its macroscopic cross section ald rise factor produces a smooth curve. Since thermal blackness can be obtalned from the scattering cross section and absorption cross section for solid cylindrical slugs, the use of this curve will enable the determination of rise factors for various materials having the same diameter as a standard Hanford slug.

FUEL E'LEMENTI IRRADIATIONS

The I \& E temperature monitoring assemblies which were charged into C Pile (HAPO-159) have definitely established that the coolant temperature at the top of the annulus is significantly higher than at the bottom. The $\Delta t$ at the top of the annulus in tube 1479 ( the first new process tube to be charged with I \& $E$ slugs and a temperature probe) is 2.7 times greater than the $\Delta t$ of the water located between the ribs.

\section{HAPO IN-PIIE EXPERIMENTSS}

Ten samples of MIPB (HAPO-183) were discharged from the 2A Test Hole at KW reactor.

Two assemblies, each containing four zirconium samples, for studying the reaction between zirconium and pile gas impurities (HAPO-105) are operating in F Pile at controlled temperatures. Gamma heating is being used to adjust the temperature of the individual samples to the desired value; the temperature range of 50 to $250 \mathrm{C}$ is presently being studied.

\section{OTHER IRRADIATION TESTS}

The following routine irradiation activities were conducted during the month:

1. Ten sets of samples (HAPO-184i) were irradiated in a poison column control facility at DR pile. These irradiations are in support of an activation analysis program being carried; out by the Hanford Laboratories Operation at the request of the Division of Research of the AEC. 


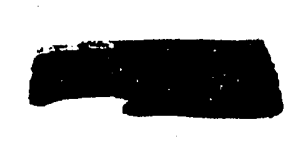

2. Eighty one samples began exposure and 124 completed exposure in the F area gamma facilities.

3. Two AF-100 samples completed exposure in the KE gamma facilities.

4. One Quickie capsule containing depleted $\mathrm{UO}_{3}$ was irradiated in the $E$ test hole at $\mathrm{F}$ pile. The irradiation was performed at the request of the Chemical Research personnel to provide a source of $\mathrm{Np} 39$ tracer.

\section{TEST FACILITIES}

The new rear nozzles, designed to minimize reactor outage time in the event of a fuel element failure, were installed on the two front-to-rear test holes at $\mathrm{KE}$ reactor.

The Thirty-Six Inch Shielding Test Faclilty at $C$ reactor was reconditirnud in preparation for the testing of various iological and thermal shieldj.g materials in support of the Plutonium Recycles Program.

One irradiation tube in the F Area gamma facility was charged w:.th irradiated cobalt for the garnma source. A gamma flux of $1.65 \times 10^{6} \mathrm{r} / \mathrm{hr}$ (as measured by a Virtoreen) was obtained. This value is $s i x$ times greater than the average. flux which can be obtained through the use of irradiated full elements.

The preliminary drawings of the Irradiation Testing Laboratory modification were reviewed and returned, together. with comments, to the Architect-Engineer.

\section{BORESCOPING}

Following the removal of the old thermocouple stringer, the RT-6 stringer channel at $\mathrm{KE}$ was borescoped to a depth of $40 \mathrm{feet}$ from the far side. The channel was clean and. in excellent condition.

The RS-3 stringer channel at $\mathrm{KE}$ was borescoped to a depth of 16 feet from the near side in an attempt to determine the cause of the stringer's sticking during its removal. The reason for the sticking could not be established; a two inch separation between graphite blocks was noted at a depth of 10 feet.

The step plug for VSR \# 24 at KE was borescoped to determine the cause of the rod's sticking. The borescoping revealed gouges which has a depth of approximately $1 / 32$ " and which contained galled metal. The step plug was replaced with a spare.

\section{VERTICAL BOWING MEASUREMENTS}

The following process tube vertical bowing measurements were made:

$\frac{\text { Tube }}{4454}$ Front $\frac{\text { Area }}{105-B} \quad \frac{\text { Date }}{12-4-56}$

\begin{tabular}{l} 
Remarks \\
\hline Up .15 at $10^{\prime}$ since $3-9-56$ \\
Up .01 at $19^{\prime}$ since $3-9-56$
\end{tabular}




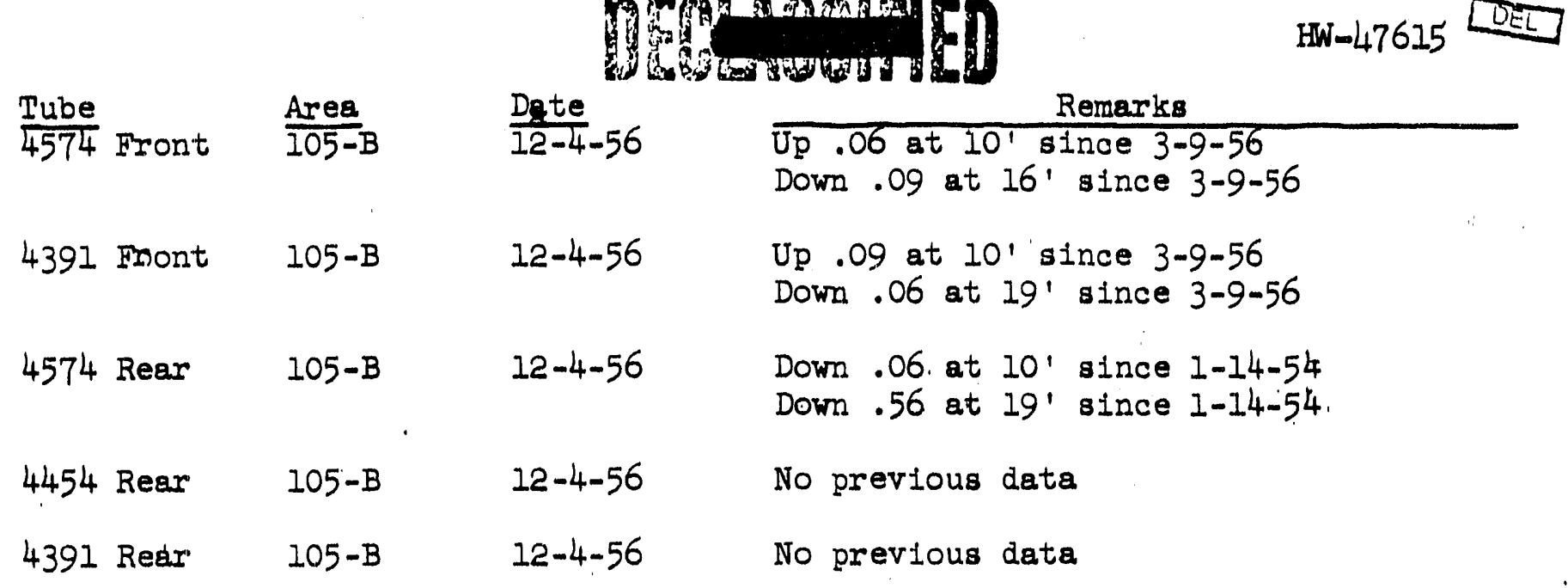




\section{COOLANT TESTING OPERAT ION}

\section{6-KE In-Reactor Single Pass Tubes}

Rear face piping for Tube 3043 was modinied by the installation of a control valve assembly and heat exchanger to permit operation at elevated single pass temperatures. The installation was scheduled to use KERR outage time to complete as much of the work as possible. Additional outage time will be required to install a zirconium tube and the necessary control instrumentation.

Replacement control valves and individual tube flow instrumentation vere installed for all single pass tubes to insure more reliable operation.

\section{ELMO Loops}

Operation of the EIMO Loops continued in accordance with established programs. Significant information or activities are as follows:

EIMO 2: Test sections of typical KER stainless tubing and welds were inspected and appear to be free of pitting or corrosion.

ELMO 7: Operation of the Loop continued for checking sections of KER tubing and cap gaskets. The loop was thermally cycled 320 times during the period of December 22 through December 28.

ELMO 9: The aluminum sulfate treated water test was completed and preliminary data indicate corrosion rates approximating that of normal high purity water. A new test was initiated using aluminum shavings to increase the effective aluminum surface area. The test will evaluate the affect of hydrogen, produced by the aluminum shavings, in reducing corrosion rates.

Mock-Up Tubes

A test was initiated to determine the corrosion behavior of fuel elements with flexible ribs in process water at 1100 . Other tests continued with no change in program or significant data reported.

\section{Organic Program}

ORA-1: Alterations necessary to Insure safe operation of the loop were completed and shake-down runs were Initiated at month's end.

ORA-2: A 17 day operating period was completed with the shutdown of the $\mathrm{KE}$ reactor for the KER outage on December II. A total of 45 gallons of MIPB was irradiated to an estimated $35 \%$ polymer content. The low temperature irradiation produces a viscous amber colored flutd. Offalte irradiation at $300 \mathrm{c}$ prodncts a black liquid of reduced viscosity. Thermally oracking of the ORA-2 produced Irradiated organic, by heating to $250-300 \mathrm{C}$, produced a liquid similar to the off-site thermal: and radiolytically damaged material.

HAPO has established a cooperative venture with off-plant sites to accelerate the organic program. Irradiated samples have been or w1Il be shipped off-site for detailed physical and chemical analysis, heat transfer and burnmout studies as follows: 


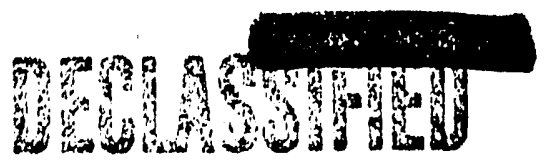

$\mathrm{HW}-47615$ DELL

One gallon to KAPL on December 14; 18 gallons to KAPL on December 20, for redistribution to the Naval Research Laboratory and Mine Safety Appliances Research Corporation; and three gallons to Atomics International. All data obtained through tests or analyses of this materlal will be available to HAPO, thereby saving duplication of complex test and analytical equipment.

The ORA-2 loop was refilled and started up on December 21 to produce material with higher polymer content. After ten hours of operation, flow to the inpile section was lost due to malfunction of both of the small canned motor Chempumps. Cause of the pump fallures has not been determined. A larger Chempump was installed on December 28 and the loop will be reactivated as soon as practical.

ORA-3: Loop tests have shown sheet aluminum and flexitallic gaskets to be acceptable for use with organics. Further tests of KLR valves have failed to develop a completely acceptable packing material. Solid teflon appears to be satisfactory for service up to $500^{\circ} \mathrm{F}$.

The program for converting KFR Loop \#I to organic coolant is proceeding satisfactorily. Scope for the modified instrumentation was completed during the month.

The Coolant Testing Operation participated in pre-scope studies for additional organic in-pile recirculation loops.

KarR Facility

The KGR tie-in was carried out December 11 to December 21, 1956.

Two hundred twenty $9 i x$ and sixth-tenths hours of the 241.6 hour outage were charged to KER work. This figure includes a 10.6 hour poison outage and start-up preparations. Actual KER installation and testing work required approximately 205 hours of outage time. This work was originally scheduled for 192 hours.

The majority of the scheduled construction work was completed and about onethird of the testing work was accomplished. Work accomplished during the outage was as follows:

1. Installation, lagging, and hydrostatically testing of reactor piping for all four loops.

2. Installation of zircaloy KER tubes for Loops 2,3 and 4 .

3. Cold flow Acceptance Test Procedures on Loops 2, 3 and 4.

4. Abbreviated hot Acceptance Test Procedure on Loop 2.

Installation delays and mechanical difficulties prevented completion of the scheduled work.

The Acceptance Test Procedures included heating the 10op, by using fourteen welding machines, to $250^{\circ}$, and then opening the dump valve at a system pressure of $1650 \mathrm{psi}$. Due to system heat losses, primarliy from the in-pile 
tube, it was impossible to operate the system above $185^{\circ} \mathrm{C}$. In the course of the hot flow test the dump valve inadvertently opened and IION was interrupted to the test heating section. Although the welding machines were irmediately shut off, the heating section ruptured, resulting in damage to adjacent piping and necessitating a curtailment of test actirities. The cause of the spontaneous operation of the dump valve has not been determined.

The KER tubes were placed on single pass process water operation for reactor start up. The remaining Acceptance Test Procedures will be carried out during scheduled outages with the out-of-plle equipment operating at the time the reacto: is shut down. The tests will be carried out while the reactor graphite is cooling and it is anticipated that the desired test conditions may be achieved and the tests performed with a minimum amount of outage time.

On December 6, curing a pressure test of KGR nozzle-to-tube connections, a section of KER tubing was ruptured at 4,000 psi hydrostatic cold. This tube had been previously hydrostatically tested at 5,000 psi cold, and had been subsequently thermally cyaled 24 limes. Three possibilities have been advanced as to the cause of the failure:

1. Construction of the thread relief. The test section was not typical of the in-pile tubing due to the sharp thread relief. A radius is provided on the thread relief of the in-pile tubes.

2. Metal fatigue arising from the thermal cycling.

3. The test section may have contained a bidden flaw. The in-pile tubes have been completely radiographed. The test section had not been radiographed.

A test program was estabifshed to theimally cycle test specimens from 10 to 320 times, and bursc test. An additional sample with the sharp thread relief was thermally cycled 40 times.

The test samples were burst tested December 29, with the following results:

\section{\# of Crcles}

0

10

20

40

\#40

80

160

320

xsharp thread relief
Burst Pressure (hrdrostatic cold)

13,250

13,000

12,750

11,500

13,250

14,250

14,500

13,000

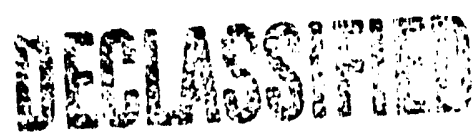

These data will be considered in the establishment of final KGR loop operating temperatures and pressures. 


\section{COMPONENT TESTING OPERATION}

Irradiated Material Examination

Detailed examination of twenty-three tubes of irradiated metal was completed during the month.

\section{Process Tube Corrosion Monf.toring Program}

Ten pile process tubes were examined in the basin facilities, and nine tubes, averaging eight samples per tube, were examined in the Metallurgical Laboratory during the month. Severe external corrosion was observed on tube 1283-D and medium external corrosion noted on tube 0383-D. Detailed wall thickness, rib helght and external corrosion measurements are reported in BW -47637 .

In-pile measuremedts of 49 process tubes were made using the Probolog; 10 at $C$ PIle, 22 at $F$ PIle and 17 at $\mathrm{H}$ Pile. The C.P1le tubes were measured since these tubes will be charged with I \& $E$ slugs. The results are reported in $\mathrm{HW}-47557$. The $F$ PIle tubes were scheduled for removal because of low calculated residual wall thickness. Difference between the Probolog measurements and calculated values were quite large. These tubes are located in the Pringe zones and the largest errors between calculated and measured values have previously been noted in these areas. These results are reported in $B W-47286$. Of the $B$ P1le tubes, 11 were scheduled for removal because of low calculated residual wall thickness. The remaining six were selected in a further effort to verify or refute calculated residual wall thickness using the corrosion index. Probolog results indicated that two of these six tubes had residual wall thicknesses below the criteria and hence they were removed. These results are reported in $\mathrm{HW}-47101$.

Facilities and Equipment Development

A new dial indicator whlch will be used to more accurately measure the rib heights of process tubes was installed in the 189-D Metallurgical Laboratory.

Two new Model E Probologs were recelved from the Shell Development Co. These pieces of equipment will be used as spares for existing equipment. One was loaned to the Radiographic Testing Operation until they can receive theirs presently on order.

Responsibility for Project CG-689, Slug Saw and Etching Equipment for the 105-C Metal Examination Facility was assigned to personnel of the Equipment Development Operation, Irradiation Processing Department.

\section{Panellit Gauges}

One hundred and six panellit gauges using DT-100-TM Switches were installed in the $K E$ panellit board by authority of Production Test IP-13-BE. These and the 92 gauges previously installed in KW operated satisfactorlly during the wonth with no failiries to date. 


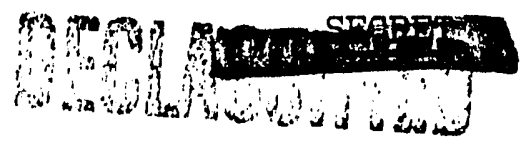

$H W-47615$

DE:

INVENTIONS

AIl Research and Engineering Operation personnel engaged in work that might reasonably be expected to result in inventions or discoveries advise that, to the best of their knowledge and belief, no inventions or discoveries were made in the course of their work during December except as listed below. Such persons further advise that, for the period therein covered by this report, notebook records, if any, kept in the course of their work have been examined for possible inventions or discoveries.
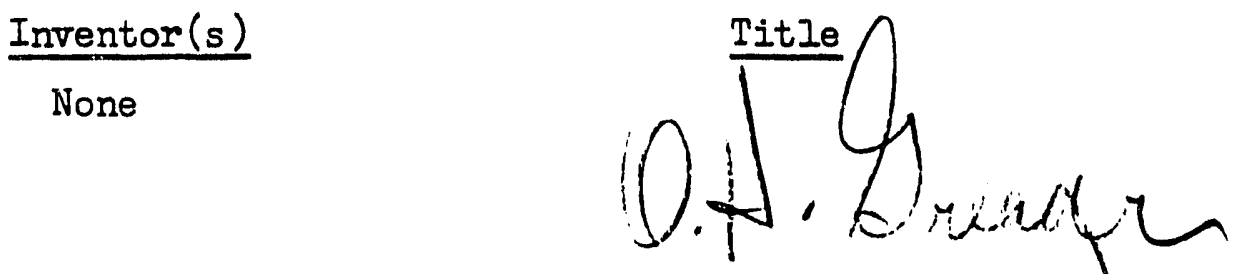

MANAGER, RESEARCH AND ENGINEERING IRRADIATION PROCESSING DEPARTMENT 
PRODUCTION AND REACTOR OPERATIONS SUMMARY

December, 1956

Input production (Pu) for December was 110.5 per cent of forecast and represents a new record, exceeding the October, 1956 record by 4.0 per cent. This achievement resulted from record production at the DR and KW Reactors (exceeding previous bighs by 13.7 and 10.8 per cent, respectively), and from above forecast power levels and time operated efficiencies.

Output production for December was 107.5 percent of forecast due to discharges during unscheduled outages late in the month. Discharge concentrations were maintained according to previous plan, including the redefinition of ruptureprone tubes to account for the drop in inlet water temperature experienced at this time of year!

Increases in the maximum established power levels (including burnout) were achieved at B, DR and KW where previous records were exceeded by 90,5 and 60 units, respectively. These increases resulted from additional cooling water following the installation of project CG-558 fecilities at B Reactor, good continuity of operation at $\mathrm{DR}$ and improved flattening at $\mathrm{KW}$.

Thirty-nine reactor outages, of which fourteen were scrams, resulted in an overall time operated efficiency of 77.1 per cent. Forecast was 75.0 per cent.

Fifteen ruptures of regular metal slugs required 172.2 outage hours for removal from the reactors. Five of these occurred at $C_{y}$. five at $H$, two at $K W$ and one each at $D, F$ and $K E$. Three ruptures were removed by the "quickie" method; one each at $\mathrm{C}$, $\mathrm{H}$ and $\mathrm{KW}$.

Under the tube replacement program, tubes were installed in 19 channels from which problem tubes had been previously removed at B Reactor, 49 tubes (including 24 problem tubes) were removed and replaced at $F$, and 75 regular tubes were removed and replaced at $\mathrm{H}$.

Significant 1tems of equipment experience during the month were: (I) The KE Reactor was shut down December 11 to 22 for the tie-in of the $1706 \mathrm{KaR}$ facility; (2) B Reactor resumed operation December 8 concluding an outage for the installation of CG-558 faclifties; (3) is BPA power fallure, caused by the opening of a relay on the No. 2 BPA line at Midway, scramed the $D, F, H$ and $K E$ Reactors December 27. D and $K E$ were unable to recover from the scram due to insufficlent reactivity; (4) Separan feed faclitities were completed at all water plants except $F$ and $K W$.

There were no disabling infurles during the month. One formally-investigated Radiation Incident was experienced at $\mathrm{KW}$ when a Processing Operation employee recelved a localized over-exposure to his hand from partlculate coniamination as a result of handling a contaminated hose nozzle.

Statistics for the Processing, Power, and Radiation Monitoring Operations in the individual reactor areas are tabulated on pages $\mathrm{Cg}-1$ through $\mathrm{Cg}-6$ of this report.
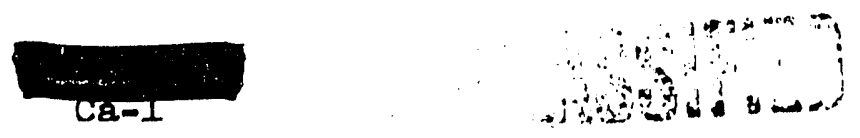


\section{B-C REACTOR OPERATION}

DECEMBER, 1956

GENERRAL

I. Respongibility

Assigned responsiblifities of the B-C Reactor Operation remained unchanged during December.

II. Organization

N. E. W1lson, Supervisor-in-trainlng, was promoted to Supervisor, Radiation Monitoring, B-C Radiation Monitorlng Operation, effective December 1.

W. N. Lusebrink, Supervisor, 100 Operations II, was transferred from B Processing Operation to the Supplemental Crews Operation.

C. A. Junghans, Superv1sor, 100 Operat1ons II, was transferred from H Processing Operation to B Processing Operation.

III. Forse Report

General

P.A. \& P.D. Operation

B Processing Operation

C Processing Operation

Power Operation

Radiation Monftorlang Operation

Maintenance Operation

November 30 December 31 Net Change

NE E Total NE E Total Total

Total

11

13

$\begin{array}{lll}35 & 8 & 43\end{array}$

328

10614

40

120

\begin{tabular}{rrr}
1 & 1 & 2 \\
1 & 3 & 4 \\
35 & 7 & 42 \\
30 & 8 & 38 \\
106 & 14 & 120 \\
17 & 5 & 22 \\
114 & 21 & 135 \\
\hline
\end{tabular}

$11421 \quad 135 \quad 11421 \quad 135$

0

$2-1$

$-\frac{1}{2}$

$-2$

0

0

0

$\begin{array}{lllll}307 & 59 & 366 & 30459 & 363\end{array}$

$-3$

Personnel chenges during December Included 6 transfers into B-C Reector Operation, 6 transfors out, 2 terminations, and one deactivation.

\section{Safety \& Security Exporience}

There wero 12 modical troatmont cases and no disabling injurlos during

December. No securlty Vlolations wero incurred.

V. Personnel Activities

An Information-dinner moeting was hold at the Dosert Inn on Decomber 3 for exempt people of B-C Reactor Operation. Flfty-four people attended and F. F. Fitrmaurice, guest spoaker, discussed the functions of his organization.

R. K. Brownlng, Toch Grad, was assignod to B Sh1ft, B Processing for trainting. 
Weekly radiation information and tralning meotinga primarily for non-excims personnel in the $B-C$ Reactor Operation were started December 21.

Factory representatives provided demonstration and training sessions for 23 maintenance craftsmen on parder actuated tools. This has resulted in aroundthe-clock arailebillty of personnel trained and authorized to operate powder actuated tools.

VI. Non-Routine Reports Issued

No significant non-routine reports were issued this month.

VII. Inventions and Discoveries

All persons engaged in work that might reasonably be expected to result in inventions or discoveries adFise that, to the best of their knowledge and belief, no inventions or discoverles were made in the course of their work during the perlod covered by this report.

\section{B-C ADMTNISTRATION AND PERSONNEL DEVELOPMENT OPERATION}

\section{Administrative Actirities}

Exempt appraisals were completed and approved. A comparison of salaries of first-line supervisors with their non-exempt salarles was initiated to discover and correct inequities.

A statistical report on scientiflc and englneering manpower was completed (in accordance with an AEC request through IPD).

\section{Persionnel Development}

Three training meetings (for supervisors) on the new Non-Exempt Personnel Development Program were conducted. This essentially completed the supervisory tralning portion $n$ f the program during which all but two sunervisors attended a meeting. A priority listing of supervisors scheduled to attend the course in Principles of Business Management was directed to M.L. Mickelson.

III. Cost Control Activit1es

Proposed projects for the FY 1959 Budget were discussed by all IPD component representatires at a meeting held on December 18. I. I. Huffman represented the $B-C$ Reactor Operation.

IV. Landlord Activities

Conversion of the 105-C Counting Room Into office space for the C Processing Operation resulted in the relesse of three offices. They were reassigned to englneering components, permitting a better centralization of their people. 
I. Production

The reactor was down at the beginning of the month on Project CG-558. After startup on December 8, a new B Reactor maximum operating level was established. The new high exceeded the prevlous record (December, 1954) by $90 \mathrm{MW}$. This increase resulted from the higher flows and pressures made possible by the CG-558 modifications.

Input production (Pu) for December was 145.9 per cent of forecast due primarily to a higher-than-forecasted operating level and efficlency. Power level was limited during the first operating period by an arbitrary tube power limit.

II. Operating Experience

\section{A. Operating Continuity}

There were two scheduled and three unscheduled outages at B Reactor in December as follows:

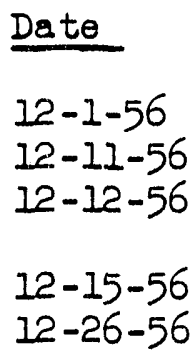

Cause

Project CG -558

Faulty Panellit Jumper Improper Valving on Panellit Manifold

Excessive heat cycle

Charge - discharge

Total Outage Hours
Outage Hours

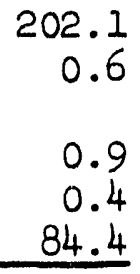

0.9

0.4

84.4

288.4

The initial startup following the CG-558 Outage was made at 10:05 p.m. on December 8, 1956. The reactor was shut down after elght minutes of operation to remove a special PC chamber that had been used as a monitor during the initial startup. Operation was again resumed at 10:55 p.m. on December 8, 1956 concluding an outoge that was initiated at 4:40 p.m. on September 22, 1956 for Project CG-558.

\section{B. Equipment Experience}

During discharge of polson while operating, the charge machlne of the Polson Colum Control Facilety, hung up on tube 1579-B and could not be removed during operation. It was removed during the following shutdown.

Nineteen problem tubes wore replaced and charged. Throe of the twontytwo roported cloar last month wore found to contain some small pleces of tubing and their replacement was postponed.

\section{Other S1gnificent Items}

A leak developed in the junction box on the 30 inch bullding drain as a result of excessito back pressure from the now effluent line junction box. Construction forces rerouted the junction box vent line to the old exteting 30 inch vont which relleved the beck pressure and the loak problom.

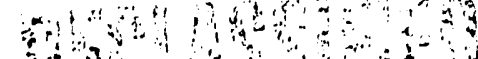




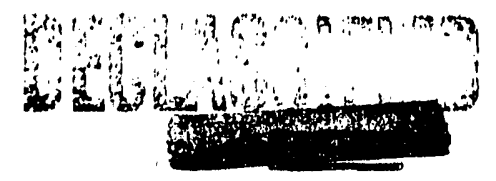

HW -47615 DEI.

Repalrs to the 1904 outfall wore completed and the reactor effluent Plow was diverted ont1rely through 107-B. The 107-C west basin had boon used during ropalrs.

III. Improvement Bxpertence

A. Production and Process Tests

1. Scram transiont tosts woro conductod during the schoduled shutdown of Docomber 26, 1956.

2. Production Tost IP-2A, "Special II-N Loading", was startod during the Docomber 26, 1956 outage. Thts Inrolvod charging a total of 58 tubes of whlch 24 woro charged w1th $\mathrm{E}-\mathrm{N}$ matorlal, 8 w1th numberod urantum, and $26 \mathrm{with}$ rogular matorlal. Fight spocially callbrated vonturis wore installed on solected tubes.

\section{B. Projecta}

Projects in progress at B Reactor during the month were: CG-558 "Reactor Plant Modifications for Incroased Production", CG-666 "Zono Temperature Monttor", CG-684 - "Frosh A1r Systom", CG-669 "Wator and Gas Loak Iocating Equipmont", CG-665 - "Motal Loading Fac1I1t10s", and CG-667 - "Improvod Space Ut1lfzation". Furthor dotalle concorning project may bo found in the Semt-Monthly Project Status Report 1saued by the Fac1litios Inglnoerlag Oporation.

\section{Othor}

Dual sensing lines were installed between the raw water Groves ralves and the ralvo p1t headors, to servo as a backup to the high tank sonsing lines.

IV. Events Influenc1ng Costs

A. Orert1me Usage

A total of 16 exompt and 26 nonexompt overtime hours were required to provide necesaary manpower at $B$ Reactor during tho month.

B. Others

1. During the equilibrium perlod following the intial startup, the averago dally gas 108 was 6300 cublc foot for hollum and 9300 for $\mathrm{CO}_{2}$. Hellum was used for four startups. The total bellum used during these porlods, above the avorage, was 116,500 cublc foet.

2. Nineteen problem tubes were returned to serrice.

ROCESSING OPERATION

\section{Production}

The C Reactor Input production (Pu) for December was 100.4 percent 
of the forecast. The operating control point which was increased from $900 \mathrm{KW}$ to $970 \mathrm{KW}$ tube power (average ten hottest tubes) on November 28, was reduced to $920 \mathrm{KW}$ tube power on December 22 as a result of five regular metal ruptured elugs occurring during the perlod of December 7 through December 21. No further ruptures were experienced.

II. Operating Experience

A. Operating Continuity

There were elght unscheduled outages at $C$ Reactor in December as follows:

Date

$12-5-56$

$12-6-56$

$12-7-56$

$12-9-56$

$12-17-56$

$12-19-56$

$12-20-56$

$12-21-56$

$12-21-56$

\section{Cause}

Panellit scram - Thbe 1969 (IP-1-A)

Panellit scram - Gage shorted to

Panellit board

Rupture outage - Thube 2576

Rupture outage - Tube 2878

Rupture outage - Thbe 2584

Temporary polson discharge

Rupture outage . Tube 2482

Rupture outage - Tube 2176

Fales rupture indication

Total Outage Hours
Outage Hours

28.9

1.5

25.6

4.2

62.6

4.3

24.5

2.4

$\frac{2.8}{156.8}$

Three of the five ruptures experienced during the month were stuck, requiring removal of the tubes as well as the ruptures.

\section{B. Equipment Experience}

The reactor was shut down on December 5 by a Panellit trip on Tube 1969. At the time the reactor scramned, header 19 gave a full-scale reading on the gamm monitor and a substantial increase was recelved on the 107 inlet recorder. Since this tube was a run-to-rupture tube (PT-IP-1-A) charged w1 th E Motal, it was discharged on the basis of the above ment1oned rupture indications in addition to a olightly higher plgtall reading then the surrounding tubes. Examination of the motal revealod no rupture, but did show that the front face insert hed come loose from the cap and had been discharged w1 th the metal. It is felt that the increase in tube pressure was causod by the front face insert coming loose and moring down the tube against the metal. The tube contained only $17 \mathrm{IS}$ Slugs in the charge.

Two tubes, 2576 and 2584, wore roplaced as a result of stuck ruptured slugs during Decomber.

Tube 2482 was belng remoted as a result of a stuck rupture on December 21 when the tube separatod in the reactor. The channol was blanked off as an air tube ponding removal of the romaining soction of tubing at a later dato. 
III. Improvement Expertence

A. Production and Process Tests

1. PT-IP-1-A - "IFvaluation of I \& E Slugs Operating at H1gh Spec1flo Powerg - A Panoll1t trip on Tubo 1969, charged with Is sluge, occurred on December 5. This scram is discussed under "Iquipmont Experfonce" of this report.

2. PT-105-611-A - Dotermination of the Effect of P1le Varlablos upon Slug Dimons lonal Stability" - Ono tubo chargod in accordance with the production test was discharged at goal concontration on December 17.

3. PT-105-634-A - "In P1lo Cocked Slug Test" - A total of 13 tuber contalning cocked slugs and four control tubes were chargod under the production test on December 6 . F1ve tubes charged under this production test wore discharged at goal concentration on December 17. Approxlmately the same degreo of corrosion attack was noted on all threo cocked slugs. However, the corroglon attack on the slugs cocked agalnat the s1de of the tube was spread over a wlder area then that on the alue with the upstream ond cocked.

4. PT-IP-19-A - "P1 lot Cherg1ng of I \& E Fuel Elements" - A total of 50 tubes was charged with I \& E slugs on December 17. This makes a total of 101 tubes of I \& $\mathbb{E}$ materlal charged Into the reactor under thls production test.

B. Projects

1. 112-Tube Charge-Discharge Fac111ty - CG-651 - The Installation of the rertical game monttoring system and the high pressure chargo-dischargo water pump was started durlng the month. A total of 125 thermocouple leads was pulled from the control room to the diacharge area on December 19 to be used on this project.

2. Work continued on Projects CG-584, "Molsture Monitoring Equipmont," and CG-600, "190-C Pump Modifications."

C. Other

1. Thermocouples - A total of 462 spare thermocouples was installed betwoen the control room and the discharge area in the existing duct. Of the 462 total, 125 of the therncouples are of a special type for use in evaluating Improved types of thermocouples (and insulation) on the 112-tube chargedischarge facility.

Seven faulty outlet tube thermocouples wore roplaced with new spare thermocouples durlag December.

IV. Events Influenc1ng Costs

A. Overt1me Usage

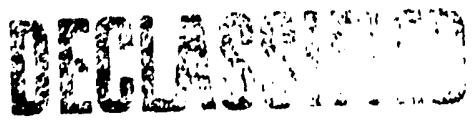

A total of 490.2 manhours overtime was required for shutdown 


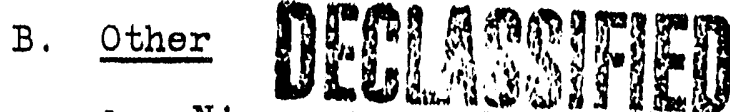

1. Nine outages during the month resulted in 156.8 hours of downtime.

2. There were five regular metal ruptures, three, of which were stuck.

3. Twelve outage hours were required to process 50 I \& E tubes.

\section{B-C POWER OPERATION}

I. Operating Experience

The river level varied between 384.0 and 390.6 feet whlle turbldity ranged between 2 and 45 P.P.M. during the month. Coagulant feed was increased and Separan feed was initiated on December 10 and continued through the high turbidity period. Super-quality water was maintained throughout the month.

\section{TI. Equipment Experience}

181 Bullding - On December 27 a tugboat was obtalned from Priest Raplds to remove tumbleweeds from the pump suction bays.

105-B Valve P1t - At 4:25 a.m. on December 26 the Groves valve opened up reducing the export pressure from 223 pounds to 198 pounds. After inspection and resettins, no reason was found for 1 ts operation.

105-B Bullding - A leak was discovered in the Fire and Sanitary header west of the bullding on December 25. The header was repalred and returned to service on December 31. During excavation of the Fire and Sanitary header, the sensing line to the south h1-tank was broken. The Iine was repalred on December 28.

\section{Improvement Experience}

\section{A. Projects}

1. CG-558 - "Reactor Plant Modifications for Increased Production" Dr. Pajnter, of M.I.T., investigated the by-pass piping vibration in 190-B Annex. As a result of his investigation, the by-passes are not being used. Work was started on December 11 to put the 190-B Pump Room turbine condensers back in service. The job is 35 percent complete.

2. CG-600 - 100-C Area Altorations - No. 12 process pump was installed. To date the Acceptance Tests have not been satisfactory.

3. CG-616 - "Installation of Ac1d Feed Equipment, 100-B and 100-C" Project was completed except for clean-up and removel of some old equipment.

4. CG-714 - "Steam Pole Replacement, 100-B Area" - The Installation of 20 steam poles completed Part I of the $\$ 100,000$ Emergency Project CG-714. 
IV. Fronts Influencing Costs

A. Orertime Uaage

The total overtime worked for Power Operation for the month of Decombor was 229.3 manhours. Th1s flguro is high due to concontrated training efforts prior to start-up of 190-B Annex.

B. Other

1. Water treatmont costs were higher due to Increased raw water turbidity.

2. Malntenance costs wero higher due to the removal of tumbloweeds at 181 and around the area, the repalr of the Fire and Sanitary hoader and sonsing line to the south hi-tank at 105-B.

\section{B-C RADIATION MONITORING OPERATION}

I. Radiation Occurrences

There were no radiation incldents requiring formal inventigation and reporting.

On December 18, followlng the discovery of radioactive gas in the 105-B valve pit, aurreys were made of the plpe tunnel in 190-B Bullding. Dose rates from gas as high as $60 \mathrm{mrads} / \mathrm{hr}$ wero found in the tunnel and as high as 6 mrads/hr in the 190-B lunch room and at the top of the stairs to the tunnel. No exposure to Power personnel was involved. The back-up of redloact1 10 gav from 105-B to 190-B resulted from turning off the 190-B Bullaling fans. The condition was corrected by returning the fans to service. Since this occurrence, the plpe tunnels between 105-B and 190-B here been barricaded to prevent air from flowing from 105-B to 190-B.

II. External Exposure Control

A maximum dose rate of $4 \mathrm{r} / \mathrm{hr}$ was experlenced in the 105-B Discharge Area whilo pushing an irradiatod motal ploce from the far elevator pad into tho basin with a 10 foot length of plpo. Irradisted solld aluminum dummies were romoved from a process tube, at the front face of B Reactor, at a maxtmum personnel dose rate of $3 \mathrm{r} / \mathrm{hr}$.

Start-up surveys of the B Reactor front face after the CG-558 Outage rovealod one unshielded process tube channel. Noutron and game intensities of the beam omanating from the channel woro, 25,000 slow noutrons/ $\mathrm{cm}^{2} / \mathrm{sec}$. (200 mrom/ $\mathrm{hr}), 25,000$ intermediato noutrons $/ \mathrm{cm}^{2} / \mathrm{sec}$. (520 mrom $/ \mathrm{hr}$ ), and I r/hr. A maxImum personnel dose rate of $500 \mathrm{mrem} / \mathrm{hr}$ was recolved wht lo maldng the survoys. Tho channel wa proporly shtelded durling the polson-discharge outage.

At the C Reactor, personnel rocolved a maximum dose rate of $3 \mathrm{r} / \mathrm{hr}$ whilo in. atalling a quickie funnel. The maxlmum dose rate exporlonced durling handling 3X Ballo was lr/hr. A small particlo glving a dose rate of 500 rads/hr at four 1nches was found on the floor of tho Motal Examination Fac1lity P1t No. 1 after the plt was drained. The particlo was flushod to tho drain at a personnel dose rate of $75 \mathrm{mr} / \mathrm{hr}$. 
III. Contamination Experience

Effluent water vepor leaks from the effluent water system lnside the 105-B exclusion area gave dose rates as high as $300 \mathrm{mrads} / \mathrm{hr}$ at ground level. The vapors were blown into the etorage area and the personal clothing of elght people was contaminated to a maximum level of 2,000 $c / m$. The clothing was released the same day. Leaks in the effluent system were repalred on the following outage.

Gas leaks at the front face and the top of the B Reactor have caused high dose rates in those locations and in the work area since start up following the CG-558 outage. Maximum dose rates due to gas were 4 rads/ $\mathrm{hr}$ at the front face, I rad/hr at the top of the reactor, and $2 \mathrm{rads} / \mathrm{hr}$ in the work area. Repairs are belng made as leaks are located. Gas leaks have also been a problem at the front face of C Reactor, w1 th readings as hlgh as $1 \mathrm{rads} / \mathrm{hr}$ belng observed.

The filter of 65 cubic feet air sample taken in the 105-B storage area gave a surface dose rate of $300 \mathrm{mrads} / \mathrm{hr}$ from effluent water vapor. The area was restricted until alr conditions retumed to normal. No other of the 108 air samples taken indicated act1rity densities above permisgible limits.

Sixty-elght vehicles were surveyed; a spot of contamination was found in one truck bed. The contamination level was $4,000 \mathrm{c} / \mathrm{m}$ and was reduced to below detectable limits.

IV. Events Influencling Costs

1. Overtime Usage

A total of 195 hours of overtime was used during December.

\section{B-C MAINTENANCE OPERATION}

I. Equipment Experience

A. Instruments

1. CG-558 Outage - Calibration checks were completed on all equipment and instrumentation involved in CG-558. Mechanical difficulty wes experlenced with the Game Monltor prior to stertup.

Since atart-up, forelon materlal (scalo and rust) have caused plugging of panellit lines, gas system, 190 flow transmitters, and purge system transmitters. This is expected to continue for several monthe unt1l high flows s.loar the systems.

2. Temperature Monitor - The B Reactor scanning circult was modified during the CG-558 outage, as problems of interrupted scanning were belng experlenced. However, the flexowriter continued to require approximately ono mochenic full time to maintain continulty during the month. Further development work toward eliminating the problem has been inltiated by englneering groups.
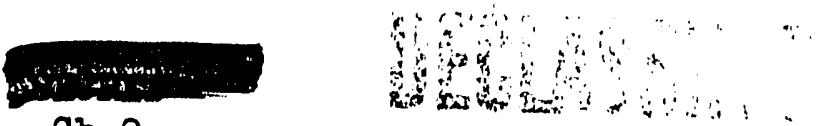
Electrical Malntenance Inotallod 462 thermocouples at C Reactor during the outage of December 17; 337 for the temperature monitor and 125 for PT IP-3IF in conjunction with devolopment of motal shoath thermocouples for CG-651. These spares vere installed from the control room to the top of the unit thermocouple duct. Tho work was accomplishod in 24 hours of which only 7 hours roar face time was required.

3. Pressure Monitor - 011 was placed in all B Reactor panollit gaugo . Ilnes to dampen̈ rscillation. Howeror, some gauges continued to oscillato critically.

4. Gas Systom - On Docomber 18, the Foxboro Dewcoll was placed in operation at $B$ Reactor. Dow point mapa can now be taken more rapidiy.

5. The hot startup chamber for the $C$ Reactor $P C$ unit fallod and was replaced. High radiation levele precluded oxamination of the chamber to dotermine the cause of the fallure.

B. Electrical

1. CG-558 start-up - All equipmont functioned wojl during and followIng the start-up of December 8 except that the VSR clutches required resetting and, just prior to start-up, VSR\#26 was tiod out because of a bad clutch. The rod was roturned to sorvice during the December 26 outago.

C. Mochanical

1. Gas Loaks - During the December 26 outage at B Reactor, efforts wero concentrated on elimination of gas leaks on the unit. Stops taken included: tightening 119 rear face nozzles and all front face nozzles, inspection of all HCR seals and repair of two leaks, and 1nstallation of bellowg boots. The water leak rate experienced since December was eliminated, but the gas 108 s was not reducod.

2. Rear Face Deflector - A deflector plato wes fabricated and Installed at the base of the B Reactor rear face over the old thormocouplo duct. Th1s deflector extends along the entlre bottom of the unit to prevent slugs from lodging on the exhaust duct at the base of the untt.

3. ESR Inspection and Repairg - During the B Reactor HSR gas seal Inspoction on December $261 \mathrm{t}$ was found that No. 2 and No. 7 rods wero binding. Inspection revealed that both gulde sleores (In seal to allen rod and seal) were broken, and pleces of the materlal had entered the stop plug guldes binding the rods. The seal on No. 2 rod was torn pormitting sevore gas loss. The rods wero frood up and returned to service wl thout gulde sleover.

\section{Shift Maintenance Actirities}

Prior to the CG-558 atertup, pile time was avallable to install 19 procoss tubes in channels whlch had been cleared of problem tubes during November.
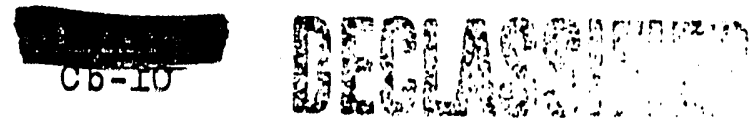


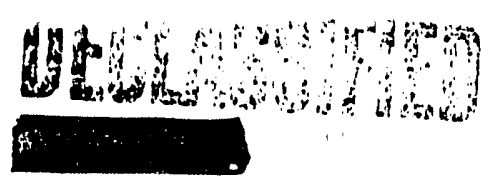

HW -47615 DEL

III. Maintenance Engineerlng and Planning and Scheduling

A. Instrument Ensineering

1. C Reactor Galvanometer System - With the present low levol-high level toggle switch in the No. I Gelvonometer Circuit, reactor atartups can be made with the switch in the wrong position. The clrcultry is being studied to determine if an additional decade range can be installed in the Aryton shunt to oliminate the need for the swltch.

2. B Reactor Gas Instrumentation - A long-range study of the B Reactor gas system instrumentation has been inftlated. The purpose of the study is to determine the causes of rocurring difficulties with flow, pressure, and make-up instrumentation, and to make recomendations for Improvements to the system as a whole.

B. Electrical Engineering

1. Instrument Supply Standby Transformer-105-C - It was established that the transformer voltage is in the range in which the $C$ Reactor process Beckmang may become unstable under conditions of motor starts in the 190-B Annex. Installation of three singlephase 5-KVA transformers (with three, f1ve percent taps) in place of the existing transformer, was recomended.

2. 181-B Switch Gear - The under-voltage relaye for the 181-B sw1tch gear instelled during the CG-558 outage were determined to be inadequate for the service because of insufficlent time delay. New relays of the proper desten were selected and all necessary information was supplied to Design to expodite relay procurement and installation.

C. Planning and Schoduling

1. Product1ve Maintenance - A Product1.vo Maintenance system went into effect on December 3 in B-C Area. The transition was smooth and without confusion or dfficulty. Inspection orders issued during Docember were 140 Class A Overhauls and 156 Class B Overhouls for all crafts.

2. Property Accountab1l1ty - The Maintenance Manegor was assigned responsibility for all uninstalled. equipment in 100-B-C Operation. Planning and Scheduling has written and obtalned approval on procedures to prorldo a mothod of accountablilty.

IV. Events Influencing Costs

A. Overt1mo Usage

Overtime for B-C Operation work was 779.0 hours. Overtime for CG-558 and assoclated work was 318.1 hours. The total premium hours are charged to $B-C$ and will increase costa.

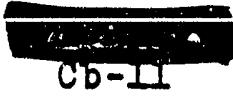




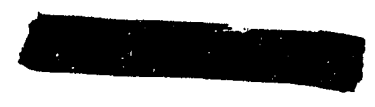

BWT -47615

$D E L$

B. Other

Ixtra labor was ut1lizod to ropalr and service oqulpment made avaliable during the CG-558 outage at B Reactor.

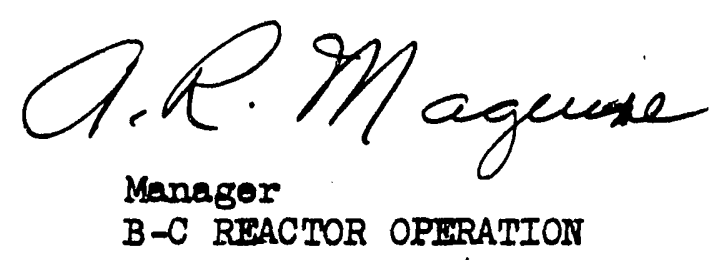

A.R. Maguiro:GSS 
KE-KW REACTOR OPERATION

DECEMBER, 1956

\section{GENERAL}

\section{Responsibility}

The assigned responsibilities of the KE-KW Reactor Operation were not changed during December.

\section{Organization}

There were no changes of organization or organizational nomenclature during the month.

III. Force Report

November 30 December 31 Net Change

General

A. \& P. D. Operation

$\mathrm{KE}$ Processing Operation

KW Processing Operation

Power Operation

E NE Total

E NE Total Total

Radiation Monitoring Operation

Maintenance Operation

Supplemental Crews

$\begin{array}{lllllll}1 & 1 & 2 & 1 & 1 & 2 & 0\end{array}$

$\begin{array}{lllllll}4 & 1 & 2 & 1 & 1 & 2 & 0\end{array}$

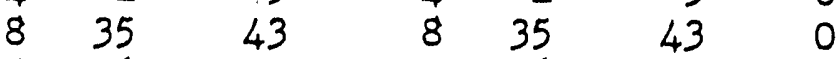

836

44

1375

88

836

44

1376

$89+1$

$\begin{array}{ll}19 & 132 \\ 19 & 65\end{array}$

27

918

27

151

$19 \quad 135$

$\frac{10}{72} \quad \frac{65}{363} \quad \frac{75}{435}$

$\frac{10}{72} \quad \frac{65}{366}$

154

0

$\frac{74}{438}$

$+3$

H. T. Wells, KE Processing Operation Manager, terminated December 28, 1956, for purposes of re-assignment to the Atomic Power Equipment Department at Vallecitos Atomic Laboratory.

J. T. Baker assumed the duties of Manager, KE Processing Operation.

J.H. M. Miller, Supervisor, Project Engineering Operation, transferred to $\mathrm{KE}-\mathrm{KW}$ Reactor Operations and assumed the duties of Manager, KW Processing Operation.

W. N. Lasebrink assumed the duties of Supervisor II, Supplemental Crews, to replace J. F. Cline who transferred to the Hanford Laboratories Cperitior.

Personnel changes during the month included eleven transfers in, seven transfers out and one termination.

\section{Safety and Security Experience}

There were no disabling injuries during the month. Fifteen medical treatment injuries were reported.

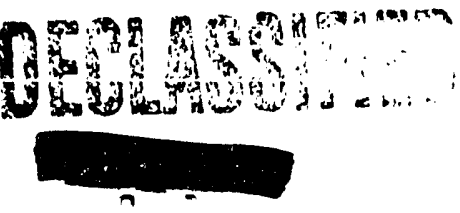


One security violation was incurred as the result of a lost document.

The IPD Central Health, Safety and Security Comittee conducted an inspection of $\mathrm{K}$ Plant buildings and facilities on December 13.

\section{Personnel Activities}

James T. Ramey, Executive Director, Joint Committee on Atomic Energy, and Senator John 0. Pastore, a member of the Comittee, visited KE-KW Reactor Operations.

A supervisory information and dinner meeting was attended by members of $\mathrm{KE}-\mathrm{KW}$ Reactor Operation supervision, Processing Chief Operators and guests.

A representative of the Ramset Company conducted training classes for all Maintenance personnel who use the Ramset powder-actuated tool.

Eighteen members of supervision attended an information meeting on Costs and Budgets, conducted by R. A. Connell.

W. I. Steinkamp, Technical Graduate, completed a rotational period with the Maintenance Operation and was re-assigned.

VI. Non-Routine Reports Issued

No significant non-routine reports were issued this month.

VII. Inventions and Discoveries

All persons engaged in work that might reasonably be expected to result in inventions or discoveries advise that, to the best of their knowledge and belief, no inventions or discoveries were made in the course of their work during the period covered by this report. Such persons further advise that, for the period therein covered by this report, notebook records, if any, kept in the course of their work have been examined for possible inventions or discoveries.

\section{KE-KW ADMINISTRATION AND PERSONNEL DEVEIOPMENT OPERATION}

\section{Administrative Activities}

The KE-KW Reactor Operation Maintenance personnel needs and excesses were reviewed and pertinent information submitted to the other plants for use in personnel placement.

Dates of last medical examinations for all $\mathbb{B}$ Plant personnel were furnished to each component.

The Master Evacuation Plan was reviewed. Comments and corrections were submitted to Health and Safety Operation. 
II. Personnel Development

Two meetings were held with $K$ Plant supervisors to review the non-exempt personnel development program.

An opinion survey of K Plant supervision was conducted to determine the priority and types of personnel development courses desired.

A priority list of $\mathrm{K}$ Plant supervision was submitted to the Communication and Personnel Development Operation for the Professional Business Management-I Course.

V. R. Griffith, Training Specialist, made training contacts with seven exempt and 69 non-exempt personnel of the various IPD Power Operations during the month.

\section{Cost Control Activities}

Potential budget items were reviewed with Facilities Engineering Operation to facilitate formulation of the FY-1959 Plant Acquisition and Construction Budget.

\section{Landlord Activities}

A letter of policy and instructions relative to administration of the $100-K$ Area Landlord function was issued.

Standby authorizations were issued to Maintenance forces to perform snow removal and weed burning as needed.

\section{KE PROCESSING OPERATION}

\section{Production}

Input production was 93.0 percent of forecast and was 35.0 percent below the previous record high. This decrease was principally the result of the tenday KER tie-in outage and an outage caused by a disturbance of the Bonneville Power Authority supply system.

\section{Operating Experience}

\section{A. Operating Continuity}

Outage time for the month totaled 315.5 hours. Operating contimity was affected by the following events:

Date Outage Hours

\section{Remarks}

12-5 33.1 Unscheduled. Panellit trip caused by rupture in 3654-KE. Outage time utilized for charge-discharge of 200 tubes.

12-7 i9 Unscheduled. Beckman trip during start-up.

12-11 231.0 Scheduled KER tie-in outage.

12-21 $10.4 \quad$ Scheduled. Poison discharge. 
Date Outage Hours

$12-27 \quad 40.1$
Remariss

Onscheduled. Scrammed by disturbanco: in BPA System. Outage time utilized for planned maintenance and charge-discharge of 411 tubes.

\section{B. Equipment Experience .}

1. Ruptures - A Panellit scram occurred on December 5 while a rupture indication was being investigated. The rupture was located in tube 3654-KE and was discharged by normal charging machine pressures. The ruptured piece was from Lot $\mathrm{K}-384$ and had attained an exposure of 422 $\mathrm{MWD} / \mathrm{T}$.

2. Flux Monitor - Difficulty was experienced with the Number 3 Beckman following replacement of an electrical cable. This cable was found to bind, preventing proper adjustment of the chamber. Necessary repairs were made during the poison discharge outage of December 21, eliminating the difficulty.

3. Vertical Safety Rods - During the KER tie-in outage, the following VSR work was accomplished:

a. Completed and tested the work authorized by Design Change 138, "VSR Latch Assembly Modification KE and KW."

b. Completed and satisfactorily tested the ISA revision authorized by Design Change 123, "VSR - Ball 3X - LSA Modifications 105-KE, KW."

c. Replaced VSR Number 24 .

d. Corrected four VSR gas seal leaks.

e. Replaced cylinders on VSRs $24,29,40$ and 66.

4. Efflufint System - A small ground surface cave-in was observed on November 27, near the outlet valve box of "B" Retention Basin. Facilities Engi neering personnel investigated the situation and recommended excavation of the location to determine the cause. Necessary authorizations are being prepared at month end.

5. Renovable Graphite Stringers - Five of the eight existing removable ga'aphite stringers were successfully removed during the KER tie-in outage and three of these were replaced with new stringers. The fabrication of the additional stringers is in progress. The installation of the three new stringers permits more efficient reactor control.

6. Ball $3 X$ System - The carbon steel balls of nineteen ball hoppers were removed. The hoppers were filled with boron coated steel balls. A total of 21 hoppers of carbon steel balls was shipped to $B, D R$, and $F$ Reactors.

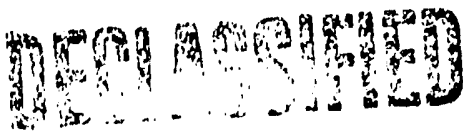


7. Mattress Plates - Damaged mattress plates were removed from the pickup chutes during the December 27 outage. All of the remaining plates are in good condition.

\section{Improvement Experience}

A new type of rear nozzle was installed on the two front-to-rear test holes. This installation will permit discharge of samples or samples and tube together without removal of the rear nozzles.

IV. Events Influencing Costs

A total of 220 overtime hours were used to accomplish necessary work during the various outages of the month.

\section{KW PROCESSING OPERATION}

\section{Production}

Input production for the month was 114.6 percent of forecast due principaliy to higher than forecasted levels. A new maximum level, 60 units higher than the previous maximum, was reached on December 28.

\section{Operating Experience}

\section{A. Operating Contimity}

Outage time for the month totaled 88.1 hours. Operating continuity was affected by the following events:

Date Outage Hours Remarks

$12-12 \quad 52.9$ Scheduled. Charge-discharge of 458 tubes.

$12-18 \quad 33.2$

$12-20 \quad 2.0$ Unscheduled. Rupture - Tube 0777-KW. Outage extended for charge-discharge of 178 tubes.

\section{B. Equipment Experience}

1. Ruptures - The reactor was shut down on December 18, with indications of a rupture in tube 0777-KW. The charge could not be moved using the regular charging machine pressures, necessitating removal of the tube and charge together with forces up to 2500 pounds. The ruptured piece was of Lot $\mathrm{K}-201$, one of the six regular metal pieces in the upstream portion of a "C" metal charge. The average exposure for these six pleces was $854 \mathrm{MWD} / \mathrm{T}$.

Five hours after reactor operation was resumed, indications of another rupture were found. Upon reactor shutdown, a rupture was verified in tube 3181-KW, and the tube was discharged by the "Quickie" method. This rupture was of Lot Z-196 and had attained an exposure of 408 $\mathrm{MWD} / \mathrm{T}$. 
2. Vertical Safety Rods - Modification of the latching mechanism, with exception of the plunger blocks, was completed for all rods during the month. Design work on new plunger blocks is in progress.

\section{Events Influencing Costs}

Overtime requirements were 95 hours, primarily for charge-discharge and minimum crew requirements. This figure is the highest monthly usage for the fiscal year but is 18 percent below the FY-1956 average.

\section{SUPP LEMENTAL CREWS OPERATION}

\section{Equipment Experience}

The "C" elevator width in the old reactors is being reduced seven and one-half inches as a result of the CG-558 Project. New procedures and material handling methods for efficient charge-discharge operations under the change of elevator space conditions are under study.

\section{KE-KW POWER OPERATION}

\section{Operating Experience}

There were no equipment failures or oporational malfunctions that contributed to a reactor outage or delayed a reactor startup during the month.

\section{A. Electrical Power Disturbances}

An under-voltage relay trip on the Number 3 incoming $220 \mathrm{KV}$ line caused the fans at 105-KE to trip out on December 15. The line was cleared by electrical distribution and returned to normal service the following day.

At 3:00 a.m. on December 27, the Number 2 Bonneville to Midway line.momentarily relayed out as a result of a 50 percent voltage drop for a period of four cycles. The resultant power surge scramed the $\mathrm{KE}$ Reactor. No power equipment was effected by the surge.

\section{B. Weter Treatment}

Increasing turbidity of the raw water necessitated an increase in coagulant dosage for proper treatment on December 10. On December 15, at 183-KW, it became necessary to improvise a manual Separan feed method to maintain satisfactory water quality. This method was utilized until December 21, when the permanent Separan feed facilities were completed and put into service. A similar improvised method of Separan feed was infilated at 183-KE on December 2I, pending completion of this plant's permanent feed facilities, which are 90 percent complete at month end.

II. Equipment Experience

A. Number 1 High Lift Untt - 190-KE

An inspection on December 20, prior to placing this unit in service, disclosed an electrolyte leak on the center cell of the rheostat. Investigation revealed faulty epoxy cell construction. Repairs to this cell were 
completed, and the unit was returned to service on December 28.

B. Underwater Inspection of KE \& KW 181 Facilities

McCray Marine Construction Company of Seattle completed an underwater inspection of forebay, pump suction wells, and screens at 181-KW on December 12 and at 18I-KE on December 13. The inspections revealed the bottom of all suction wells to be free of sand. Suction bells and the inside of the traveling screens were in good condition. Numerous items of construction material were recovered from the suction wells in both areas. As a result of the inspection, the rate of sand accumulation in the area between the trash rack and traveling screens and in the forebay proper have been plotted for future reference in both areas.

C. Number 4 High Iift Phase Balance Control - 190-KW

A faulty phase balance control switch on the Number 4 high lift unit was inspected and repaired on December 29.

D. Electrolyte Cooling Water Flow - 190-KE

The program started in November to modify the original installation of the by-pass cooling water control valves in 190-KE was completed on December 18 .

\section{Improvement Experience}

\section{A. Projects}

Backwash Valves - Replacement program of backwash valve disks was completed at 183-KW.

B. Other

Noise Abatement - 165. Building Control Rooms. - Installation of fiberglass panels on two walls of the $165-\mathrm{KE}$ control room was completed. Evaluation tests of the noise abatement afforded by these test panels are being conducted by Facilities Engineering Operation.

\section{Events Influencing Costs}

Water treatment costs increased approximately ten percent due to the bigher river water turbidity.

Fuel oil cost per unit of steam production decreased approximately two percent despite a six percent increase in fuel oll billing price effective December 1.

\section{KE-KW RADIATION MONITORING OPERATION}

\section{Radiation Occurrences}

One Radiation Incident was experlenced during the month. This involved a Processing Operations employee who withdrew a hose from the Storage Basin and

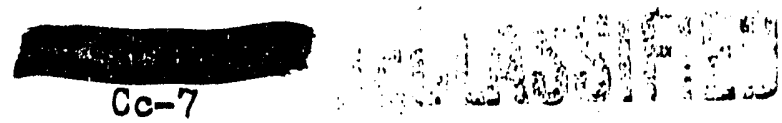


used it to flush the grating around the technical viewing pit at 105-KW. The hose nozzle was highly contaminated, resulting in the employee receiving a localized dose to a small area of his hand of 150 rads, including $2 \mathrm{r}$. This incident is further described in IPD Investigation Report entitled, "Radiation Over-exposure, No. 113, , by P. C. Jerman.

Seven Lapses of Radiation Control were reported in the KE-KW Reactor Operation. These are summarized below:

1. A Processing Operations employee contaminated his shoe while working on the wash pad.

2. KE - Two electricians were sitting in the lunchroom unaware that an irradiated graphite-thermocouple stringer was being transferred overhead.

3. KE - A contaminated piece of pipe with a maximum dose rate of $65 \mathrm{mrads} / \mathrm{hr}$ was found lying on the floor in the storage area.

4. KE - Skin contamination was found on a Maintenance employee following discharge area work.

5. KW - Contamination was found on the bed and the seat of Processing Operations pick-up truck.

6. KW - The previously mentioned radiation incident.

7. KW - Contamination of $750 \mathrm{mrads} / \mathrm{hr}$ was found on the floor underneath a step-off pad.

\section{External Exposure Control}

Thie removal of five graphite-thermocouple stringers was accomplished at 105-KE, with a maximum dose rate to personnel of $250 \mathrm{mr} / \mathrm{hr}$. Dose rates up to $100 \mathrm{mr} / \mathrm{hr}$ at 100 feet were measured while the stringers were being transferred from the $\mathrm{X}$-level to the thimble cave.

Fission product gas from a discharged ruptured fuel element spread from the storage area to other locations of the 105 Bullding. Canning the element required personnel dose rates up to $4 \mathrm{rads} / \mathrm{hr}$.

Dose rates to $500 \mathrm{r} / \mathrm{hr}$ at two inches were encountered by personnel decontaminating the 105-KE chute surfaces prior to mattress plate replacement work.

The technical viewing pit at 105-KW was drained and flushed following canning of a ruptured fuel element, with a resultant maximum personnel dose rate of $2 \mathrm{r} / \mathrm{hr}$.

\section{Contamination Experience}

A routine survey of a well car coming into 105-KW indicated contamination of $10 \mathrm{rads} / \mathrm{hr}$, including $150 \mathrm{mr} / \mathrm{hr}$ on the deck. This was reduced to below the release limit of $100 \mathrm{mrads} / \mathrm{hr}$ after extensive decontaminating. 
During decontamination of a load of dumies from 105-D, the floor of the wash pad at 105-KW became cnntaminated up to a maximum of 20 rads/hr, including $500 \mathrm{mr} / \mathrm{hr}$ at two inches.

\section{KE-KW MAINTENANCE OPERATION}

\section{Equipment Experience}

A. Instruments

1. Pressure Monitoring System - A total of 253 mercury separations were corrected during the month. Adjustments were made to 2,533 gages, 95 percent of which were range changes and functional checks completed during outages.

No mercury separation have been observed to date in 106 new type mercury switches installed early in December in 105-KE.

2. Temperature Monitor System - Thirteen controller boxes were repaired and ten balancing potentiometers adjusted during the month.

3. Safety Circuit Instmumentation - Nine Beta Monitoring chambers were overhauled and replaced.

Design Change Number 148, Dual Beckman Trip, was completed in 105-KE by the Instrument, Electrical and Engineering groups.

B. Electrical

1. Under-Voltage Relay - The instantaneous under-voltage relays in 165-KE to the 105-KE safety circuit were recalibrated from five and eight cycle delays to 20 cycle delays. This change should eliminate scrams from brief voltage reduction disturbances.

2. Electrical Tie-In - 1706-KRR - Electrical tie-in was completed; however, the safety circuit tie-in had to be disconnected due to grounds in the new wiring system. A temporary safety alarm system was designed and installed by the engineering group.

C. Mechanical

Recirculation loops Number 2, 3 and 4 were tied into 105-KE.

Orifices were installed in eight in-pile flow tubes. Stems and seats were replaced on the control valves to agree with new flow requirements. New flow transmitter piping arrangements were fabricated and installed in each in-pile flow.

The V-73 guard valve on the emergency cross-tie line was dismantled and inspected by Maintenance peraonnel and representatives of the Rockwell. Mamufacturing Company. Certain parts were replaced and specific lubrication and operating methods were recommended. The repairs and acceptance of the manufacturer's recommendations will help alleviate" ralvem operation problems. 
Shop fabricated oil baffles designed to curtall oll leakage were installed on five of the high lift pump bearings.

II. Maintenance Engineering and Planning and Scheduling

A. Instrument Engineering

An inspection of rear face temperature monitoring lead wires in 105-KE revealed that the cracking of the lead wire outer covering has increased considerably in the last six months. Some checking and minute cracking is in evidence on the individual conductor insulation. The cracking of the outer insulation near the connector provides access for moisture to enter the soldered terminal end of the connector. Plans are being formu=. lated for replacement of the thermohm leads in 1957.

B. Planning and Scheduling

Class "A" overhauls were completed on 95 pleces of general area equipment, and Class "B" on 125 pieces.

A study was completed to correlate equipment information collected by the 100-K Power Operation with that kept by Maintenance Planning and Scheduling.

The services of a tug boat were procured through the Relations and Utilities Department to remove the sunken weeds and other debris at the entrance to the 181-KE and 181-KW trash racks. The work was accomplished by anchoring the tug and washing the material into the main river stream with the propeller of the tug.

\section{Events Influencing Costs}

A total of 783.6 hours of overtime, 99.2 percent of forecast, was worked in $K$ Plant as compared to 223.8 hours last month. The completion of scheduled work during the 1706-KER outage required the increase in overtime over that worked during the previous month.

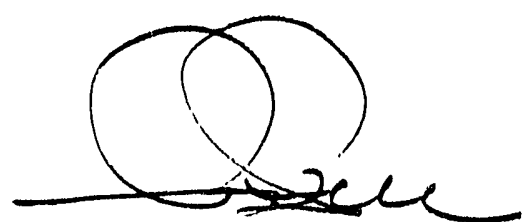

R. S. Bell

Manager

KE-KW Reactor Operation

RS Bell: CE:prb 


\section{D-DR REACTOR OPERATION}

DECEMBER, 1956

I. Responsibtlity

The assigned responsibilities of the D-DR Reactor Operation were not changed during the month.

II. Organization

O. I. Olson was transferred from the Chemical Processing Department to the Radiation Monitoring Operation as a Supervisor.

III. Force Report

\begin{tabular}{|c|c|c|c|c|c|c|c|}
\hline & & oven & er 30 & & acen & 31 & Net Change \\
\hline & $\underline{\mathrm{NE}}$ & $\underline{E}$ & Total & $\underline{N E}$ & $\underline{E}$ & Total & of Total \\
\hline D-DR General & $I$ & $I$ & 2 & 1 & 1 & 2 & 0 \\
\hline D-DR Admin. \& Per. Dev. & 1 & 3 & 4 & 1 & 3 & 4 & 0 \\
\hline D Frocessing & $3 \overline{6}$ & 8 & 44 & $3 \overline{6}$ & 7 & 43 & -1 \\
\hline DR Processing & 31 & 8 & 39 & 31 & 8 & 39 & $\overrightarrow{0}$ \\
\hline D-DR Power & 115 & 14 & 129 & $11 \overline{5}$ & 14 & 129 & 0 \\
\hline D-DR Rad. Monitoring & 18 & 5 & 23 & 18 & 6 & 24 & +1 \\
\hline D-DR Maintenance & 131 & 22 & 153 & 132 & 22 & 154 & +1 \\
\hline Totals & 333 & 61 & 394 & 334 & 61 & 395 & +1 \\
\hline
\end{tabular}

IV. Safety and Security Experience

There were 85 medical treatment cases and no disabling injuries during December. Assigned personnel incurred no security violations during the month.

All persons assigned to or in 100-D Area the afternoon of December 21 were invited to a safety meeting presented by D-DR Reactor Operation personnel. A skit based on safety and having Christmas as its theme plus music and refreshments were highlights of the meeting.

V. Personnel Activities

The D-DR Reactor Operation Manager's Monthly Information Meeting for exempt personnel was held on December 5 .

Numerous training sessions on post $C G-5 \dot{58}$ operation were presented, and attended by area personnel.

VI. Non-Routine Reports Issued

Letter, H. G. DeVoss to T. W. Hauff, "Impact of Top Secret Classifications Reactor Operations", December 4, 1956.

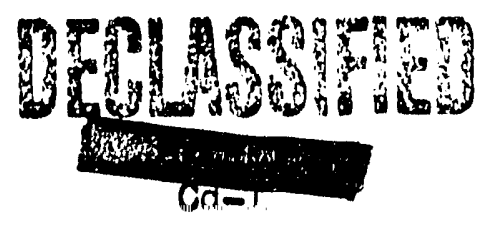




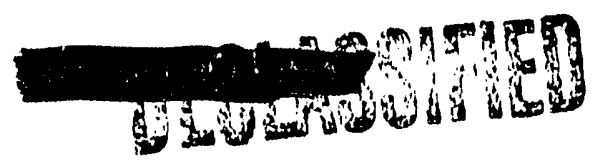

\section{Inventions and Discoveries}

All persons engaged in work that might reasonably be expected to result in inventions or discoveries advise that, to the best of their knowledge and belief, no inventions or discoveries were made in the course of their work during the period covered by this report. Such persons advise that, for the period covered by this report, notebook records, if any, kept in the course of their work have been examined for possible inventions or discoveries.

\section{ADMINISTRA TION AND PERSONNEL DEVELOPMENT OPERATION}

\section{Administration Activities}

A procedure was issued to appropriate 100-D Area personnel establishing a priority message system for use in rapidly informing local area personnel of significant happenings in the area.

Comments were made to the Manager, Health and Safety Operation relative to the proposed IPD Master Evacuation Plan.

A program for total housekeeping and safety inspection coverage of 100-D Area was initiated. This involved assigning specific portions of the area to Level 4 components and requesting that monthly inspections and reports be made.

II. Personnel Development

The orientation of first line supervisors in the application of the new Non-Exempt Personnel Development Program was completed. All first line supervisors were contacted in a series of five meetings held during November and December.

The Work Simplification Program continued with nine D-DR Reactor Operation and two Process Technology Operation exempt employees attending two meetings.

At month end, two Technical Graduates are on Rotational Training assignments within D-DR Reactor Operation. One Technical Graduate completed his assignment during the month.

\section{Landlord Activities}

Work related to the landlord function in progress during the month included additional blacktopping of parking lots and roadways, repair of road signs, initial alterations to Bullding 1713-D to provide offices and laboratory facilities for engineering work, elimination of the railroad crossing northwest of Building 108-D, and painting at Building 184-D. Also the first detailed monthly housekeeping and safety inspection was made of that portion of the area assigned to the Administration and Personnel Development Operation. 


\section{FROCESSING OPERATION}

I. Production

Reactor input production was 103.9 percent of goal forecast. Equilibrium power levels were limited by tube outlet water temperatures of $105 \mathrm{C}$.

II. Operating Experience

A. Operating Continuity

Date of Outage Outage Hours

$\begin{array}{ll}12-13-56 & 49.9 \\ 12-17-56 & 0.6 \\ 12-21-56 & 31.3 \\ 12-27-56 & 30.3\end{array}$

Cause

Rupture in 3279-D.

Investigate suspected rupture, none found.

Water leak in 3279-D.

BPA line failure caused a line power surge that shut the reactor down.

Total 112.1

On December 13, rupture indications including a ten pound increase in Panellit pressure were received from tube 3279-D. The rupture was discharged with the charging machine using normal discharge forces. After pressure testing the tiube, it was recharged with regular metal. The tube itself had been replaced in February, 1956. On December 17, the reactor was shutdown when rupture indications were again received from header 31. As no rupture could be found from a rear pigtail survey, operation was resumed. Following the brief outage ( 0.6 hours) of December 17 , dew points and condensate collection rates increased rapidly necessitating an outage for leak testing on December 21. Tube 3279-D was found to be leaking.

An electrical power surge from the BPA system resulted in a reactor scram on December 27. Start-up was delayed approximately 12 minutes by problems associated with VSF removal. Though recovery was made and the reactor operated for 58 minutes, insufficient reactivity prevented further operation.

B. Equipment Experience

A new improved commuications system including a paging facility was energized during the month.

Repair of a faulty rear seal on the zircalloy 2 tube, 3586-D was completed. The tube was recharged with PT-105-555-E material.

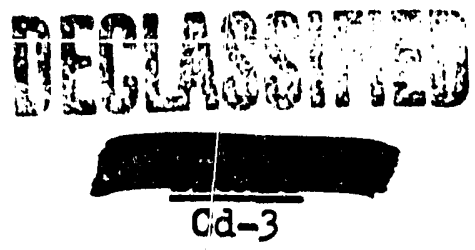




\section{B. Equipment Experience (Continued)}

Flow tests of orifice zone 10 tubes indicate that Panellit protection in low flow situations is less than desired because of orifices that are too restrictive. To increase the amount of protection, Paneliit gauges were adjusted downward as far as operational conditions permitted. During the December 21 outage, all front face caps, lug rings, and pigtails on zone 10 tubes were visually checked for possible weak points that could result in loss of water pressure - none were found. It is planned to operate as is until the $C G-558$ outage at which time the reactor is scheduled for re-orificing.

The cause of the sticking of VSR's during the December 27 scram recovery has not been completely resolved. AII VSR's have since been lubricated with molykote and tested satisfactorily.

\section{Improvement Experience}

\section{A. Production and Process Tests}

The poison spline in tube 2486-D was removed during the December 13 outage in order to recharge the tube. The spline had been inserted for flattening purposes as a part of PT-105-618-A, "Poison Spline Flexible Control System".

\section{B. Projects}

Initial work on the Project CG-667, "Improved Space Utilization 105-B, D and F Buildings", was accomplished during December. Among the areas worked on were the Men's Room, valve pit areas, and in the accumlator room. ilork will be continued during the next several months.

Removal of an orifice from the elght inch filtered water supply line to the storage basin resulted in an estimated flow of $2,700 \mathrm{gpm}$. Since this is not sufficient for "last ditch" back-up supply during the CG-558 outage, it will be necessary to install a raw water tie-in similar to that used at Building 105-B during their CG-558 outage.

\section{DR FROCESSING OPERATION}

\section{Production}

New maximum level and input production records were attained at DR Reactor in December. The maximm power level was five units and the input production 3975 units above the previous highs which were attained in November, 1955. The December maximum level was 55 units above last month's high due to the seasonal decrease in inlet water temperature. Operating levels were restilicted by tube outlet temperatures of $105 \mathrm{C}$. Input production was 144 percent of the official forecast for December due primarily to the high operating efficiency (essentially 100 percent) and high average operating level.

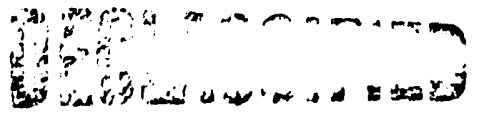


II. Operating Experience

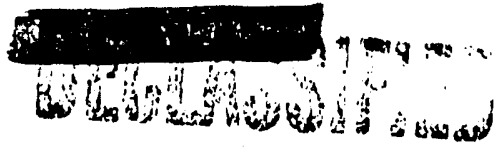

\section{A. Operating Continuity}

The operating continuity of DR Reactor was interrupted only once during December - that was on December 14 when 0.3 hours of outage resulted from a Panellit scram. The scram resulted when the valve on gage 3458-D was opened instead of the valve on 3558-D during attempts to check the pressure indicated on the latter gage.

\section{B. Equipment Experience}

The Number 2 HCR brake solenoid burned out on December 31 . Since reactor operation was not significantly affected, repair is not scheduled until the CG-558 shutdown in January.

\section{Improvement Experience}

\section{A. Production and Process Tests}

Six samples were processed for short-term exposure in the Poison Column Control Facility as authorized by PT-105-15-DR, "Irradiation Service Request Number HAPO-184".

B. Projects

Preparatory work for Project CG-558 continued during the month. Significant work included the removal of two solids feed pumps, installation of a modified pump, and installation of Panellit testing equipment ( 90 percent complete).

\section{Events Influencing Costs}

Gas loss during December was less than one-half the loss in November. This reflects the reduced losses experienced during steady reactor operation.

\section{D-DR POWER OPERA TION}

\section{Operation Experience}

Critical power condition grade "W" existed at 100-DR Area on December 14, 21 and 22. Critical power condition grade "S" existed at 100-D Area on December 14, 21 and 22.

Electrical power surges were noted on December 4 and 27 , due to trouble on the BPA System. The December 27 surge caused an outage at D. Reactor.

Water treatment in the 100-D and $D R$ Water Plants was satisfactory throughout the report period. Normal seasonal fluctuations of the river quality were experienced. Addition of .005 parts per million of Separan feed has been started at each water plant for training

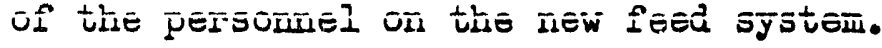




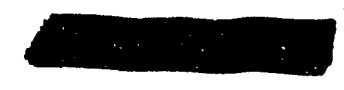

\section{Operation Experience (Continued)}

The export pumping load was transferred from 100-D and 100-F Areas to 100-B Area on December 8.

Results of a survey of the river intake channel on December 20 indicated that the channel should be dredged in the next two years because of sand bar buildup.

\section{Equipment Experience}

The new Numbers 12 and 13, 13,000 GPM pumps installed in Building 18I-D under Project CG-558 were placed in service on December 10; pumps Numbers 11 and 10 were released to Minor Construction for dismantling on December 11 and 31 , respectively.

The new Number 1, 15,000 GPM pump installed in Building 183-D under Project CG-558 was placed in service on December 10. Number 4 pump was released to Minor Construction on December 27 for dismantling.

The addition of anthrafilt to Building 183-D and DR filters was completed during December.

The solids purge pumps in Buildings 105-D and DR were released to Minor Construction for dismantling. Installation of the pumps is scheduled during the CG-558 outages.

\section{Events Influencing Cost}

The following items significantly influenced Power Operation costs during December: replacement of steam line poles; repainting of equipment in 184 Building; and extensive maintenance of Building 183-D, 183-DR and 190-D heating systems.

\section{D-DR RADIATION MONITORING OPERATION}

I. Radiation Occurrences

Two of the eleven radiation occurrences reported during the month were classed as lapses of radiation control. One lapse of control involved discovery of a radioactive particle on the jaw of a Processing employee when he was surveyed on leaving the 105-D Building Discharge Area. The particle was probably transferred onto the skin during removal of protective clothing. Film survey results indicated the maximum dose received was $120 \mathrm{mrads} / \mathrm{sq} \mathrm{cm}$. The permissible weekly exposure limit was not exceeded. The second lapse of radiation control occurred at Building 108-D when a box containing grossly contaminated tube channel broaches was transported from another plant area and left outside the established radiation zone. 
II. External Exposure Control

A dose rate of $2 \mathrm{r} / \mathrm{hr}$ was received by Processing employees while installing "quickie" discharge equipment on the rear of process tube 3279-D. A maximum rear pigtail dose rate of $500 \mathrm{r} / \mathrm{hr}$ at one inch was measured on this tube. When the "quickie" funnel was removed a meximum dose rate of $3 \mathrm{rads} / \mathrm{hr}$ was received.

After discharge of a ruptured fuel element from $D$ Reactor, a dose rate of $45 \mathrm{mr} / \mathrm{hr}$ was measured at C chute in the storage area. The exact cause of this larger than normal dose rate was not determined.

A three-inch long piece of wire found on the transfer area floor gave a dose rate of $40 \mathrm{rads} / \mathrm{hr}$ at two inches. It is believed the wire was discharged from a railroad well car during draining operations.

The burial garden trenches were partially back-filled to reduce radiation levels. Ten used gunbarrels stored on top of the ground, were placed in the trenches, at a maximum dose rate of $500 \mathrm{mr} / \mathrm{hr}$ to personnel. The maximum dose rate on any gunbarrel was $5 \mathrm{r} / \mathrm{hr}$ at two inches.

\section{Contamination Experience}

Installation of a furnace in Building 186-D for drying biological shield attenuation blocks necessitated establishment of a radiation zone approximately 50 feet square. The facilities were formerly housed in Building 189-F.

Two air samples collected in $0^{\prime}$ Far, 105-D Bullding, during poison handling were above eight hour limits for the respiratory equipment used. The maximum activity density was $1.1 \times 10^{-8} \mu \mathrm{c} / \mathrm{cc}$, decaying to $9.4 \times 10^{-9} \mu \mathrm{c} / \mathrm{cc}$ in 30 minutes. Assault masks were worn in both instances. No over exposures were involved.

\section{D-DR MAINTENANCE OPERATION}

I. Equipment Experience

A. Instruments

Panellit Data

Base Checks

Gauges Adjusted During Operation

Gauges Replaced

Mercury Separation

Defective Switches

Capillary Tube Failure

High Low Trip Checks

Impulse Iines

Response Checks

Sluggish Iines Corrected

0 il Added

Throttled
105-D 105-DR

2

0
528

0

0

4

0

2

2

8

8

101

0
-10
0

0

0

2

$\sin$

$\therefore=10$

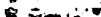


Equipment Experience (Continued

On December 14 an Instrument Technician, after bypassing the safety clrcuit features of Panellit gauge 3558-DR, opened the valve to gauge 3458-DR causing the reactor to be shut down.

Temperature Monitor System

Two tube outlet thermocouples failed at DR Reactor - both were repaired by applying 90 volts DC across the terminals to "weld" the break closed. Seven thermocouple repairs were made at $D$ Reactor during the month.

\section{Pile Control Instrumentation}

The Number 2 Control Room Beckman safety circuit controller started giving sporadic trips on December 11. Replacement of a 2050 tube and the trip-set potentiometers plus instrument adjustment resolved the problem. The controller was returned to service on December 20.

The innermost "B" test hole ion chamber for the proportional counter system was replaced on December 15 because of apparently spurious counting. When this failed to eliminate the trouble, a supply line filter was installed. The latter corrected the spurious counting noted.

\section{Gamme Monitor System}

It has been necessary to back flush several of the gamm system sample lines because of build-up of gamma background in the bottoms of the hold-up chambers. It is believed that such a bulldup was interpreted as rupture indications at $D$ Rerctor on December 17. In this instance, the reactor was shut down but no mupture could be found.

\section{Miscellaneous Instrumentation}

The radiation monitoring instruments at $107-D$ and $D R$ Basins were out of service from December 5 to December 10 because of freezing temperatures and a north wind. The wind caused basin vapor to blow back over power lines resulting in extensive ice formation on these lines and subsequent failure of the lines.

\section{B. Mechanical}

Sticking of VSR's 22 and 29 at $D$ Reactor appears to have been caused by faulty seals.

Installation of four Low Boy heaters was completed in Building 184-D during the month. These heaters had previously been used in Building 190-D. 
Mechanical (Continued)

A maintenance crew consisting of one foreman plus men of nine different crafts continue to assist Equipment Development Operation personnel in Building 189-D. Activities of the crew during the month included building of a Ball 3X mock-up, formation of vanstones on a zirconium tube, fabrication of fittings for pressure testing the tube, and the building of shunts to help effect rapid transfer of loads between generators used in performing tests.

\section{Maintenance Shift Activities}

The shift crews spent 80 percent of their time in 100-D Area, the balance was spent in $100-B, F$, and H Areas.

III. Maintenance Engineering and Planning and Scheduling

A. Instmument Engineering

Tests conducted with the Electronic Integrating Radiation Dosage Meter indicate that further development work is necessary to increase its reliability and utility. Assistance by the Instrument Development Operation of Facilities Engineering in such development work has been requested.

Improved control to prevent excessive loss of filtering material following backwash of the Building 183-D and DR filters has been recommended to the Power Operation. An orifice has been fabricated and will be installed in the effluent valve control line next month.

B. Mechanical Engineering

Investigation of the problem of flooding of Builcing 105-D and DR ventilation tunnels is continuing. The instrument engineer has been requested to design a liquid level measuring instrument for installation in Buildings 1608-D and 1608-DR to obtain data on the pump-out rate of the 1608 pumps relative to water build-up during various operating conditions.

Examination of the HCR system indicates that reported oil leaks are at flanges and other non-contiguous points in the hydraulic system. Investigations of methods of controling such leakage are being made.

\section{Planning and Scheduling}

Final preparations continued for initiation of the Productive Maintenance program scheduled to begin in January. Priorities for general area interior painting scheduled for January were established. 


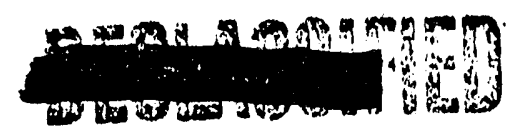

H REACTOR OPERATION

December, 1956

GENERAL

I. RESPONSIBIITTY

There were no changes in assigned responsibilities during December.

II. ORGANIZATION

The position, Instructor, Radiation Monitoring, was established, and the Analyst, Radiation Monitoring, was reassigned to the new position.

III. FORCE REPORT

General

Adm. \& Pers.Dev. Oper.

Processing Operation

Power Operation

Radiation Monitoring Oper.

Maintenance Operation

Central Maintenance Oper. Total

November 30 NE E Total NE E Total Change 
Arthur Eads, vendor's representative of White River Lumber Company of Pasco, Washington, visited 100-H Area to confer and make suggestions on use of corrugated metal outbuildings.

VI. NON-ROUTINE REPOR'SS ISSUED

No significant non-routine reports were issued this month.

VII. INVENTIONS AND DISCOVERIES

All persons engaged in work that might reasonably be expected to result in inventions or discoveries advise that, to the best of their knowledge and belief, no inventions or discoveries were made in the course of their work during the period covered by this report. Such persons further advise that, for the period therein covered by this report, notebook records, if any, kept in the course of their work have been examined for possible inventions or discoveries.

\section{H ADMINISTRATION AND PERSONNEL DEVELOPMENT OPERATION}

\section{Administrative Activities}

In addition to routine duties assigned to the function, December activities included: detailed analjses of the absentee performance of the Operation since recmganization to serve as a basis for an improvement program; establishment of a central source of all medical claims forms for the Operation; distribution of 1957 calendars, diaries, and log books; and initiation of a comprehensive study of restricted work cases in the Operation.

A report summarizing the process tube replacement program was submitted for inclusion in the HAPO Annual Report.

A total of 865 diabetes test strips were distributed.

Shift experience records were brought up-to-date for all IPD assigned pipefitters, millwrights, and welders in preparation for transferring the responsibility for rotating these employees between shift and days to the Employee Relations Operation.

\section{Personnel Development}

Completed the series of five instruction meetings for supervisors on the new Non-Exempt Personnel Development Program. In addition, conducted an information meeting for $H$ Reactor Operation clerical personnel on this program.

\section{Landlord Activities}

A wall mounted motion picture screen, building directory, and occupant name plates were installed in the $1704-\mathrm{H}$ Building during the month.

The Maintenance Operation was requested to design and estimate the cost of a bell system for 1704-H Building to ring at 12 noon, 12:30 p.m., and 4:05

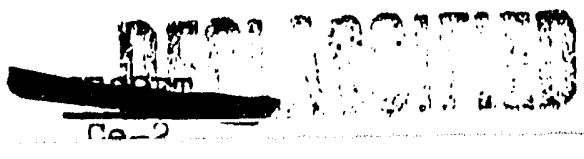


p.m., and to have sufficient flexibility to permit extension to 1703-H

Building, the new dormitory offices and 1709-H Building.

H PROLESSING OPERATION

I. Production

Input production exceeded the forecast by 2.5 per cent.

Equilibrium power level was limited by the outlet water temperature which optimizes tube corrosion.

II. Operating Experience

A. Operating Continuity

The operating continuity of the $H$ Reactor was affected by the outages tabulated below:

\begin{tabular}{|c|c|c|}
\hline Day of Month & Hours & Reason \\
\hline 2 & 137.8 & $\begin{array}{l}\text { Shutdown for the scheduled replacement of } \\
75 \text { process tubes and charge-discharge. }\end{array}$ \\
\hline 11 & 0.7 & $\begin{array}{l}\text { Scrammed because of a leaking Panellit } \\
\text { toggle valve. }\end{array}$ \\
\hline 15 & 0.4 & Scrammed by a BPA electrical surge. \\
\hline 23 & 0.9 & $\begin{array}{l}\text { Shutdown for discharge of ruptured slug } \\
\text { from tube } 2469-\mathrm{H} \text {. }\end{array}$ \\
\hline 25 & 29.9 & $\begin{array}{l}\text { Shutdown for unsuccessful discharge of } \\
\text { ruptured slug from tube } 1478-\mathrm{H} \text {. Outage } \\
\text { was utilized for charge-discharge. }\end{array}$ \\
\hline 27 & 0.5 & Scrammed by a BPA electrical surge. \\
\hline 27 & 0.3 & $\begin{array}{l}\text { Scrammed by leaking and oscillating } \\
\text { Panellit gauge. }\end{array}$ \\
\hline 28 & 29.3 & $\begin{array}{l}\text { Shut down to locate a water leak. Tube } \\
3265-\mathrm{H} \text { had a split front flange. }\end{array}$ \\
\hline
\end{tabular}

B. Equipment Experience

Thirteen outlet water thermocouples were repaired this month.

FIve hours of outage time were attributable to sticking and leaking Panellit toggle valves. Maintenance Operation personnel began development of a corrective program. 
III. Improvement Experience

A method of adjusting Panellit gauge bases during shutdowns to compensate for pressure changes resulting from tube replacement or metal discharge has been developed and tested. A two-hour reduction in outage time each month is expected from this improvement.

IV. Events Influencing Costs

The large number of outages experienced during the month necessitated the use of 41 hours of overtime.

The first of several pieces of partially irradiated B metal was successfully re-charged this month, thereby saving the cost of new metal.

H POWER OPERATION

I. Operating Experience

Process water flow was reduced five times during the month for a total of 185 hours.

Momentary power surges were experienced on December 15 and 27 due to faults on the $230 \mathrm{KV}$ electrical distribution system. Power services were not affected.

A preliminary survey of 181-H Building forebay on December 21, indicated the recurrence of a sandbar in the inlet channel at an elevation of 369.4 . Although the sandbar is of considerable size, the channel depth on either side of the restriction was more than adequate at the minimum river flow of 44,000 cfs experienced on December 27. A comprehensive survey of the sandbar will be made in the near future.

During December the Analytical Laboratories performed routine control services and special analyses on 372 essential material samples, 707 water samples, 20 lubricating oil samples, and 17 special samples.

II. Equipment Experience

The Ruggles-KIingman automatic steam inlet valve to the $184-\mathrm{H}$ Building turbo-generator was replaced with a Schutte-Koerting valve on December 3 . The new valve is designed to reduce steam leakage.

The deaerating feedwater heater was removed from service to repair a corroded inlet water manifold and the inlet water control valves. Temporary repairs were completed to the control valves since spare parts were not available. Replacement parts have been ordered.

The Beaumont-Birch coal scales were removed from No. 2 boiler and replaced with spool pieces. This removal is in conjunction with plans to eliminate all coal scales since this equipment has never functioned properly and reduces the dependability of operation.

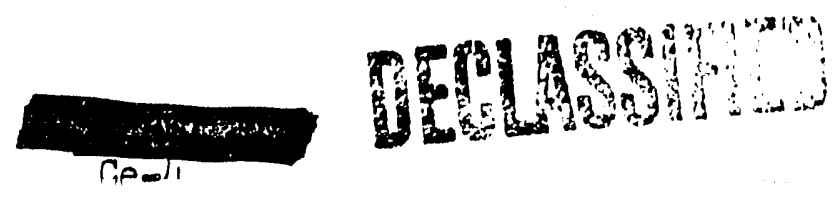


III. Improvement Experience

Installation of Separan $\mathrm{mix}$ and feed facilities is complete except for minor "touch-up" items. The feed system has been calibrated, however, this facility has not been placed in service since current raw water quality does not justify its usage.

A study is in progress by the Laboratories group to develop analytical methods for the "Essential Material" and process control of Separan.

Responsibility for routine analysis of process water and determination of non-conformity to process standards has been delegated to each Power Operation. Essential water analyses not covered by the Power Operations will continue to be run by the Laboratories group.

IV. Events Influencing Costs

Expenditure items adversely affecting normal costs included: replacement of turbo-generator steam inlet control valve, outage of deaerating feedwater heater, removal of coal scales, Class A inspections of pumping equipment, and installation of Separan equipment.

\section{H RADIATION MONITORING OPERATION}

\section{Radiation Occurrences}

There were no radiation incidents involving overexposure to personnel. Two lapses of radiation control were recorded during the month. The first - involved a Maintenance Operation foreman who incurred general contamination of his right index finger to $65 \mathrm{mrads} / \mathrm{hr}$. The source of contamination was attriouted to a contaminated SWP glove received from the laundry. Followup surveys of "clean" gloves revealed contamination to $80 \mathrm{mrads} / \mathrm{hr}$ on four gloves.

The second lapse of radiation control involved a Technical Graduate assigned to the $\mathrm{H}$ Maintenance Operation who incurred personal clothing contamination to $20,000 \mathrm{c} / \mathrm{m}$ when he picked up highly contaminated broaches at the work area radiation zone boundary. The required protective clothing was not being worn and monitoring coverage was not requested for the work.

An employee assigned to the H Radiation Monitoring Operation performed a monitoring assignment at F Reactor without wearing the prescribed protective clothing. Skin and personal clothing contamination to $6000 \mathrm{c} / \mathrm{m}$ was incurred as a result.

\section{External Exposure Control}

A maximum of $400 \mathrm{rads} / \mathrm{hr}$ was observed on the pigtail of the process tube containing the stuck rupture in tube No. $1478-\mathrm{H}$.

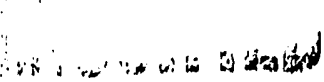


II. External Exposure Control (Cont'd)

Dose rates to personnel for rupture removal operations did not vary significantly from experienced in the past. A maximum dose rate to personnel of $2 \mathrm{rads} / \mathrm{hr}$ was incurred during installation of "quickie" equipment.

Higher than normal dose rates to personnel for tube replacement activities were encountered in localized areas in the discharge area. These high dose rates were attributed to residual internal and external contamination from raptured fuel elements.

III. Contamination Control Experience

A total of 70 vehicles were surveyed. A pickup used to bury contaminated trash was found contaminated to $10,000 \mathrm{c} / \mathrm{m}$ in the bed. It was decontaminated to less than detectable limits.

There were eight cases of contamination being spread beyond the boundaries of radiation zones during the tube replacement outage. A maximum of $20,000 \mathrm{c} / \mathrm{m}$ was observed. Decontamination of all areas was effected immediately.

There were no known cases of personal skin contamination other than the one case reported in $I$ above.

All air samples taken during the month indicated concentrations of radioactive isotopes which were below the permissible limit for the respiratory protection being worn.

IV. Radiation Training

The classrocm training program consisting of a series of 17 lectures covering all phases of the radiation protection program was presented to a group of nine IPD Radiation Monitor Trainess and eight employees from the Radiation Protection Operation.

V. Events Influencing Costs

Overtime requirements for the month exceeded forecast by 31 hours attributable to the tube replacement outage and the increased activity associated with ruptured fuel element removal outages.

H MATNTENANCE OPERATION

I. Equipment Experience

A. Instrument

All gamma monitor instruments in both sample rooms were checked and calibrated by Project Maintenance Operation. Work was continued in the repair of the water chambers. 
B. Electrical

A new shaft was fabricated and installed in the 105-H Building Nu. 8 exhaust fan after a bearing failed.

"Soil" cable was installed on the $\mathrm{CO}_{2}$ units in the $110-\mathrm{H}$ Building to prevent freezing of the lines when pressure is reduced.

Two speakers were installed at the 1701-H Building to further the safety program. Programs are recorded on tape and played back through this system during shift change.

C. Mechanical

The chain hoist at the 105-H Building wash pad was replaced with an electrical hoist.

The water supply header to the deaerators at the 184-H Building has become corroded beyond repair. A new header is being fabricated.

II. Shift Maintenance Activities

The principal shift effort was utilized in outage work at $H, C, B$, KE, and F Reactors.

III. Maintenance Engineering, Planning, and Scheduling

A. Instrument Engineering

A sketch was issued showing a new piping arrangement to improve the operation of the liquid level gauges in the 110-H Building.

B. Electrical Engineering

A lighting study was made of the sheet metal and welding shops in the 1717-H Building, and cost estimates were prepared for increasing light levels in this location.

C. Mechanical Engineering

Recommendations were made to install a steam humidifier in the air supply duct to the 190-H Building laboratory. This device in conjunction with existing humidity controls will reduce a safety hazard created by the use of volatile fluids in dry air.

Automatic shut off valves have been ordered to prevent extensive loss of helium and $\mathrm{CO}_{2}$ in case of Iine breakage between the 110-H Building and 105-H Building.

D. Planning and Scheduling

Intormation meetings were held for H Maintenance Operation supervision and craftsmen concerning the Productive Maintenance system. 
The quarterly forecast of Productive Maintenance work has been issued by the Methods Analyst and the Praductire Maintenance cards for January have been issued.

\section{Events Influencing Costs}

During the report period 180 hours of overtime were utilized. This was 1.5 per cent, which was less than forecast.

Tube replacement outage - December 3 to 6 .

Weed removal from the perimeter fences, primarily caused by tumble weeds being blown in during windstorms.

H CENTRAL MAINTENANCE OPERATION

\section{Tube Removal}

\section{A. H Ractor}

A scheduled tube replacement outiage involving 75 tubes was completed on December 6 at the rate of 24 tubes per day. The slow replacement time was caused by difficulty in removing the split tubes, and the need for broaching each channel four or five times. During installation, three tubes had to be cut off and removed when they stuck midway through the channel.

\section{B. B Reactor}

Nineteen process tubes were installed and placed in service in former problem channels on December 1. One channel had been out of service since 1944 .

C. C Reactor

An unscheduled outage occurred on Decernber 17 due to a rupture in tube 2482-C. The rupture was remored, but the tube parted leaving approximately 16 feet of tube in the channel. The channel was shielded and left for rehabilitation at a later date.

\section{D Reactor}

Tube 1078-D, a problem channel, was cleared by p hing an 18-inch section of "wadded" tubing from the channel into the gunbarrel and then removing the gunbarrel. The gunbarrel was replaced, and channel was shielded.

\section{E. F Reactor}

A tube replacement outage was scheduled for the purpose of replacing 25 regular tubes and rehabilitating a like number of problem tubes at the periphery of the unit. A total of 4 , tubee rere removed and replaced. Twenty-five of these were split and removed in the normal manner at thr rate of .926 hours per tube. Twenty-four problem tubes 
were removed and replaced at the rate of 2.75 hours per tube. An additional 13 problem channels were opened up, and removal attempted on nine. Information gained on the status of these tubes has been compiled and will serve as a background for their resoval at some future date.

F. 105 Building KER Cross-Tie Outage

Services of the Outage Specialists were utilized in directing work performed by plant forces during this extended shutdown. Additional assistance was provided for the following: repairs to Arco cask, backwash valves, vertical and horizontal safety rods, effluent line dresser coupling, poison column system, gas makeup system, and the preparation and removal of five "X"-level test hole graphite stringers.

Tabulation of process tube activities in all areas:

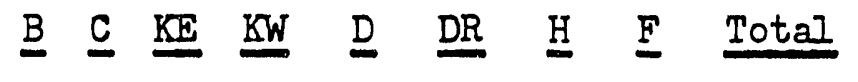

Problem Channels Cleared:

1

$24 \quad 25$

Ruptures Removed:

$$
3
$$

11

31

Stuck Charges Removed:

1

Tubes Pressure Tested:

1

13

$176 \quad 49$

230

Tubes Installed:

191

12

$\begin{array}{lll}76 \quad 49 & 148\end{array}$

Tubes Split and Removed:

$\begin{array}{llll}2 & 76 & 25 & 103\end{array}$

II. Shift Maintenance - CG-558

Outage Specialists continued to coordinate shift activities for $B / C$ Maintenance and Project Maintenance Operations groups. Pre-startup activities included the following: repositioning front face ball valves and assisting with acceptance tests, cleaning valve pit screens, correcting front and rear face water leaks, checking venturi and orlfice assemblies, and miscellaneous 190-H Building pump room repairs.

III. Sheet Metal

The major activity of the month consisted of moving the sheet metal and blacksmith shops from 1717-F Building to 1717-H Building.

IV. Painting Program

The area paint program contimed on schedule during December with efforts concentrated in 100-B Area.

V. 108-D Hot Shop

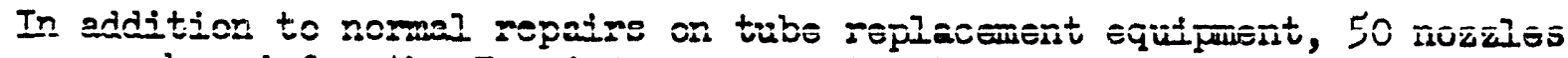
were rebored for the $I$ and $B$ program at $C$ Reactor. 
Reactor Maintenance Engineering

A. Rupture Removal Procedures

A target date of April 1957 has been established for the completion and adoption of standard rupture removal procedures to be followed by both Processing and Maintenance Operations people in each Reactor Operation. Procedures for B, D, F, and $H$ have been prepared by the Outage Specialists and are under discussion for acceptance by Processing and Maintenance Managers

B. As-Built Prints of Reactor Tooling

Prints have been brought up-to-date and corrections made to complete the as-built drawings of the Vanstone Remover and the Mark III Combination Broach.

C. CG-558 Tool Fabrication

Estimates are being prepared for the fabrication of pigtail, venturi, and orifice wrenches required to maintain the new inlet nozzles and assemblies presently being installed on Project CG-558. Tool design is now complete. Tools will be fabricated for all areas by the Central Shop on Project CG-558 arlocated funds.

D. Ramset and Sureset Fastener Training

During the month of December, 4 craftsmen and eight foremen on $B$ and $C$ shifts attended training classes and were qualified in the use of the Ramset and Sureset fastener tools. J.W. McLaughlin of Standards Engineering was the instructor. The high percentage of qualifications was made possible by scheduling the classes during shift hours.

VII. Fvents Influencing Costs

Overtime expenditures increased during December to allow painting in the shops on Saturday when shopis personnel were scheduled off, and for tiling the hall floors at 170L-B Building on Saturday when that building was vacant. Also, the sheet metal craft worked one Saturday in preparation for the KER outage.

Central Maintenance Operation's IME charges will be high as a result of:

1. Charging one-half hour/mile travel time to idle time.

2. Increase in-unit cost connected with relocation of sheet metal shop, and ".A"-class repairs of equipment in the machine shop.

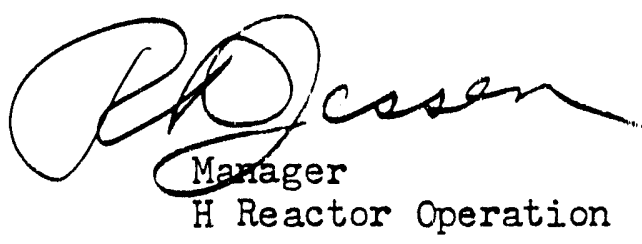

RT Jessen:HCS:CDS:met 
F REACTOR OPERATION

DECEMBER - 1956

GENERAL

I. Responsibility

There were no changes in assigned responsibility for F Reactor Operation.

II. Organization

There were no organizational changes.

III. Force Report

General:

A. and P. D. Operation:

Processing Operation:

Power Operation:

November 30 December 31 Net Change

Radiation Monitoring Operation:

NE E Total NE E Total of Total

Maintenance Operation:

11

13

358

678

104

$92 \quad 16$

2
4

2

43

75

14

108

$\begin{array}{rr}1 & 1 \\ 1 & 3 \\ 34 & 8 \\ 67 & 8 \\ 10 & 4\end{array}$

1

$\frac{1}{3}$

8

2
4
42

$--$

$-$

$-1$

$-$

$-$

$93 \quad 16 \quad 109$

$+1$

Total: 20640

246

20640

246

IV. Safety and Security Experience

There were no disabling injuries and no security violations. Four medical treatment injuries were reported. This is a new low in monthly injury experiences for F Reactor Operation; previous Low for a month was nine.

V. Personnel Activities

The series of supervisor instruction meetings on the Nonexempt Personnel Development Program was completed with all F Reactor Operation exempt personnel having recelved this information.

An orientation tour for 700 Area stenographlc and clerical employees was conducted in F Area. This tour was sponsored by $M$. I. Baker of Personnel Practices Operation - Employee and Community Relations Operation.

Seven exempt personnel attended meetings of the "Work Simplification" course. 


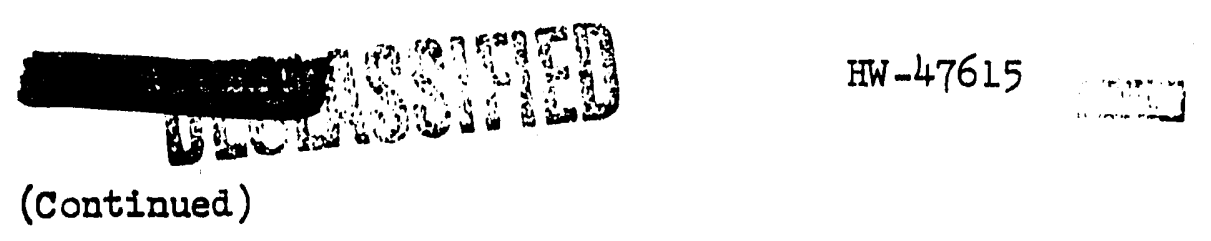

G. B. Jex was appointed to serve as a member of the I.P.D. Accident Prevention Program comittee.

R. H. Nelson, Technical Graduate, continued on rotational assignment with F Processing Operation.

VI. Nonroutine Reports Issued

No sigaificant reports were issued.

VII. Inventions and Discoveries

All persons engaged in work that might reasonably be expected to result in inventions or discoverles advise that, to the best of their knowledge and belief, no inventions or discoverles were made in the course of their work during the perlod covered by this report. Such persons further advise that, for the perlod therein covered by this report, notebook records, if any, kept in the course of their work have been examined for possible inventions or discoveries.

\section{F ADMINISTRATION AND PERSONNEL DEVELOPMENT OPERATION}

I. Administrative Activities

The week-end and hollday coverage schedule for. F Reactor Operation was established for coverage through June 30, 1957.

A priority list of personnel in F Reactor Operation for participation in the Professional Business Management course was established.

A study was completed of $F$ Reactor Operation personnel development needs for year 1957 .

A survey of 1704-F motor pool vehicle utilization showed a total of nine vehicles, with an average use of 4.82 hours/day/vehicle, and an average use of 6.0 cars in use at any given time.

II. Personnel Development

Training meetings covering the Nonexempt Personnel Development Program were conducted by the Speciallst - Cost and Personnel Development.

III. Cost Control Activities

A forecast of miscellaneous services required by $F$ Reactor Operation from Project Maintenance Operation was prepa:ed.

E. C. Bennett participated in a meeting for review of items in the 1959 Plant Acquisition and Construction Budget. 
IV. Landlord Activities

Installation of pre-cast concrete steps at all entrance doors of the 1704-F Building was completed.

General, cleanup and Improved appearance of the general grounds was emphaslzge during the month, with the removal of rock and gravel mounds, leveititag of grounds, and installation of standard parking lots.

Sub-standard conditions in the 189-F Building were corrected by removal of the Hanford Laboratories Operation test facility to 100-D Area, and clean-up of the residual contamination.

\section{F PROCESSING OPERATION}

I. Production

Reactor input production was 109.2 per cent of forecast for December. The forecast was exceeded because the December tube outage was terminated slightly ahead of schedule and there were no ruptured slug outages until the last day of the month.

Equilibrium power levels were restricted during December by the $102 \mathrm{C}$ tube outlet water temperature limit in the central zone and the $104 \mathrm{C}$ tube outlet water temperature limit in the fringe zones. Inlet water temperatures remained at a relatively high level for December and permitted an increase in maximum levels of only 20 units.

On December 31, the Pirst F Reactor rupture since March 19, 1956, was experienced. The charge was found to be stuck. Tube and charge were removed and the empty channel was blanked off. Data on the rupture are as follows:

Tube: 4263

OrIflce Zone: 4

Concentration: 375 MWD/Ton

Type of Rupture: Side Fa1lure
Charge Date: July 15, 1956

Lot Number: $\mathrm{K}-354$

Date of Rupture: December 31, 1956 Outage Hours Charged to the Rupture: 23.6 (21.1 in December)

II. Operating Experlence

A. Operating Continuity

\begin{tabular}{|c|c|c|}
\hline Outage Date & Outage Hours & Reason \\
\hline $12 / 14 / 56$ & 176.1 & $\begin{array}{l}\text { Scheduled outage for charge-discharge } \\
\text { and tube replacement. }\end{array}$ \\
\hline $12 / 22 / 56$ & 1.5 & Unexplained Panellit scram. \\
\hline $12 / 27 / 56$ & .4 & $\begin{array}{l}\text { Scram resulting from a three-phase } \\
\text { fault on Midway-McNary Line and the } \\
\text { subsequent voltage drop on the BPA } \\
\text { system. }\end{array}$ \\
\hline
\end{tabular}


A. Operating Continuity (Continued)

Outage Date Outage Hours Reason

12/31/56 21.1. Ruptured slug in tube 4263.

(Reactor down at month end - total outage time 29.6 hours.)

B. Equipment Experience

Tube Replacement - A total of 49 new tubes was installed during the month. Of these, 24 tubes were installed in reactivated fringe channels, three tubes replaced leaking tubes left empty after the November outage, and 22 tubes were installed as a part of the regular tube replacement program. Unsuccessful attempts were made to reactivate 10 other Iringe and problem tubes. At month end there were 48 problem tubes remaining at $F$ Reactor.

Stuck Charge - One regular charge was found to be stuck during the month and required 1.7 hours for removal.

Effluent Iine - Early in the month, a leak developed in a Dresser coupling in the portion of the effluent line near the 105 Building. Repairs were successfully completed during the December 14 outage.

\section{Improvertent Experience}

A. Prociuction and Process Tests

Profuction Test 1.05-1L-MR (IP-6C) Scram Transient Test - This scram tranislent test was performed on December 14, to accumulate data for mor"t: accurate scram aecovery curves. One and three-tenths hours of outilage time were used.

Prokuction Test 105-537-SR - Special Irradiations Request KAPL-113L Fifteen metal test specimens, alternated with regular slugs, were char'ged into tube 1082 under this production test.

Procuction Test 105-554-E, Rev. I - Evaluation of $7.0 \mathrm{pH}$ aud $7.3 \mathrm{pH}$ Process Water - This production test was terminated on December 28 wher the $\mathrm{pH}$ of the near side process water was changed from 7.3 to 7.0 .

\section{B. Projects}

CG-558 - Minor Construction continued work on the "last ditch" emergency water tie-in and the relocation of other water lines in the area in preparation for the CG-558 outage.

No other operationaliy significant developments occurred in connection with 105-F projects during the month.

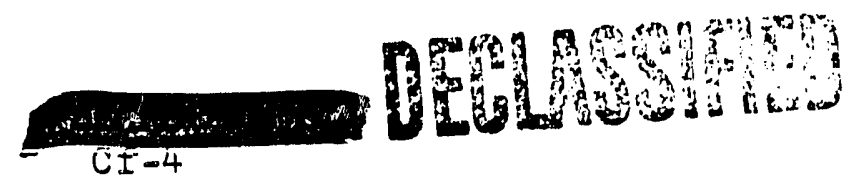


C. Other

A very low concentration solids purge test (approximately $1 \mathrm{ppm}$ ), lasting 13 hours, was performed at the instance of the Processing Operation in order to find a method for gradual removal of film to prevent sudden pressure decreases from scraming the reactor during a purge.

The installation of catwalks under the " $D$ " elevator, for pushing down chutes, was continued. Installation is approximately 50 per cent complete.

A modified Beckman amplifier with additional ranges was installed for the No. 3 Flux Monitor in accordance with Design Change 99.

Discharge elevator electrical modifications, including installation of geared limit switches, were completed.

IV. Events Influencing Costs

108.8 man-hours of nonexempt overtime and eight hours of exempt overtime were used by the F Processing Operation during the month.

Several gas leaks on front and rear face bellows and boots were repaired to reduce gas loss.

\section{F POWER OPERATION}

\section{Operating Experience}

A continuous purge of approximately 1 ppm during reactor operation was conducted from 9:00 a.m. until 10:00 p.m. on December 10.

The addition of activated silica as a flocculation aid in water treatment was necessary from December 11 to December 15, due to increase in raw water turbidity.

Loss of 440 Volt power supply to 183 Bullaing pump room on December 7 , from 6:00 p.m. to 6:30 p.m., resulted from short circuited cable on a welding machine used by Construction forces.

Due to lce formation on the area feeder power lines from vapor rising from the 107 retention basin, the power supply to 141-M Building was transferred from the normal 2300 Volt area feeder to the 2300 Volt fence lighting clrcult to assure service continuity.

II. Equipment Experience

A high potentlal test of power cables from secondary side of 13.8/2.3 KV transformer No. Y supplying 2300 Volt bus No. 1 at 181 Bullding on December 17 revealed that insulation is sat1sfactory. No further work is conte wplated on this equipment. 
II. Equipment Experience (Continued)

Soundings to the 181-F intake forebay were made on December 22 by Field Survey Operation - Construction Engineering Operation.

Number 5 process pump and motor were released to Construction forces for removal and replacement with a new CG-558 project pump on December 27 .

III. Improvement Experience

\section{A. Production and Process Tests}

Production Test 105-554-E, Revision I, Evaluation of process water with $7.0 \mathrm{pH}$ on the west half and $7.0 \mathrm{pH}$ on the east half of filter plant was terminated at $1: 30 \mathrm{p} . \mathrm{m}$. on December 28. The $\mathrm{pH}$ to treated water on the east half of the filter plant was lowered to 7.0 at that time.

\section{B. Projects}

Project CG-616 - Installation of Acid Feed Equipment - Over-all work is approximately 58.6 per cent complete. No construction activity during this report period.

C. Other

Amine Treatment to Area Steam Heating System - The injection of "filming amine 126" to the 1700 series buildings' steam heating system as a corrosion inhibitor at the rate of one gallon/24-hour period originated. I.ecember 12.

Facilities for Mixing and Feeding Separan - Installation of facilities for mixing and feeding Separan is approximately 60 per cent complete.

Replacement of Steam Line Poles - Work authorized to date is completed except for final inspect:on and clean-up.

\section{Events Influencing Costs}

During December, a total of 130.8 overtime hours was worked in F Power Operation.

Activated Silica treatment to process water to obtain specified quality water.

Class "A" overhauls to turbines and pumps in the 182, 183 Pump Room, 190 Pump Room, and the east 36 inch cone valve at 183 Head House.

\section{F RADIATION MONITORING OPERATION}

\section{Radiation Occurrences}

There were two lapses of control during December. A personnel survey revealed $10,000 \mathrm{c} / \mathrm{m}$ on the right shoe of a process operator after completion

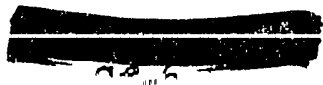


I. Radiation Occurrences (Continued)

of his work in the discharge area. The man was properly wearing the specified protective clothing. A laundered British legging is believed to have been the source of contamination.

The second lapse of control occurred during the discharging of a rupture. A process operator was working with the rupture channel when water from the tube ran into the sleeve of the rubber suit, contaminating his inner coveralls to 43 mrads $/ \mathrm{hr}$ and his right forearm to $200 \mathrm{c} / \mathrm{m}$. Prompt removal of clothing, and skin decontamination we re accomplished. The man was properly wearing the prescribed protective clothing.

II. External Exposure Control

The maximum dose rate to personnel was 2 rads/hr during the month. This maximum was encountered during the removal of a section of a process tube from the front of the reactor.

\section{Contamination Experiences}

Gas leaks from the reactor created dose rates up to 75 mrads/hr in the work area. During an interval, dose rates of $20 \mathrm{mrad} / \mathrm{hr}$ were encountered in corridors and control room. This was immediately corrected by adjusting the ventilation.

\section{Events Influencing Costs}

Two-hundred and twenty hours of overtime were worked by Radiation Monitoring nonexempt personnel during the month, occrisioned by the tube outage along with a large amount of miscellaneous work.

\section{F MAINTENANCE OPERATION}

\section{Equipment Experience}

\section{A. Instruments}

Storage Area Scales - A Toledo Scaj.e Company representative made the quarterly checks of the storage area scales. The scales were found to be within a tolerance of fo-1 pound for all welghts 0 - 2000 pounds.

Control Room Beckmans - During the December 14 outage, the Nos. 1 and 3 Beckmans were replaced with modifled Beckmans as specifled by Design Change 99. Other changes made for improved Beckman operation Included installation of a common ground at the amplifier chassis and use of a step-down transformer (220 Volt to 110 Volt) in the AC voltage supply.

P. C. System - The hot start-up P. C. chamber was replaced on December 7 and both hot and cold chambers were checked for voltage plateaus. 
B. Electrical

During the December 14 outage, the "D" elevator control wiring was revised according to Design Change 103.

A new solenold coll was installed on the No. 6 HSR, two-way - four-way valve at the $105-F$ Bullding.

C. Mechanical

A total of 49 tubes was replaced during the scheduled tube outage on December 14. Twenty-five tubes were removed using normal methods at a rate of .926 hours per tube. Twenty-four fringe or problem tubes were replaced at a rate of 3.75 hours per tube.

During the December 14 outage, mechanical checks were performed on all HCR's, and the Nos. 4 and 5 two-way - four-way valves were overhauled.

II. Shift Maintenance Activities

The major activities of the shift malntenance personnel were concerned with the tube replacement programat the F Reactor for the December 14 outage. The remalning available time was devoted to performing work scheduled under the Productive Maintenance Program.

Maintenance Englneering, and Planning and Scheduling

A. Instrument Engineering

Engineering in this category was continued on the Beckman Control systems and other reactor instrumentation.

B. Electrical Engineering

Electrical Engineering work continued on the rewiring of the 105-F discharge elevator controls.

C. Mechanical Engineering

Mechanical Engineering was devoted to malnly the following of repairs to the 108-F elevator and the start of radiographic testing of tanks to determine effects of corrosion on wall thickness.

D. Planning and Scheduling

A comprehensive survey and Inspection of pressure vessels, high pressure piplng and rellef valves in conjunction with Standard Engineering personnel were undertaken at $F$ Area.

Property Control - The tool Inventory is approximately 40 per cent complete.

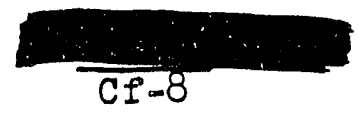


IV. Events Influencing Costs

F Maintenance personnel expended 112.7 overtime hours on facilitias outside of F Area, and 168.8 overtime hours within the Operation.

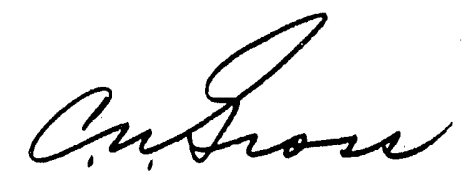

C. N. Gross, Manager

F REACTOR OPERATION

CNG : GBJ : rs 


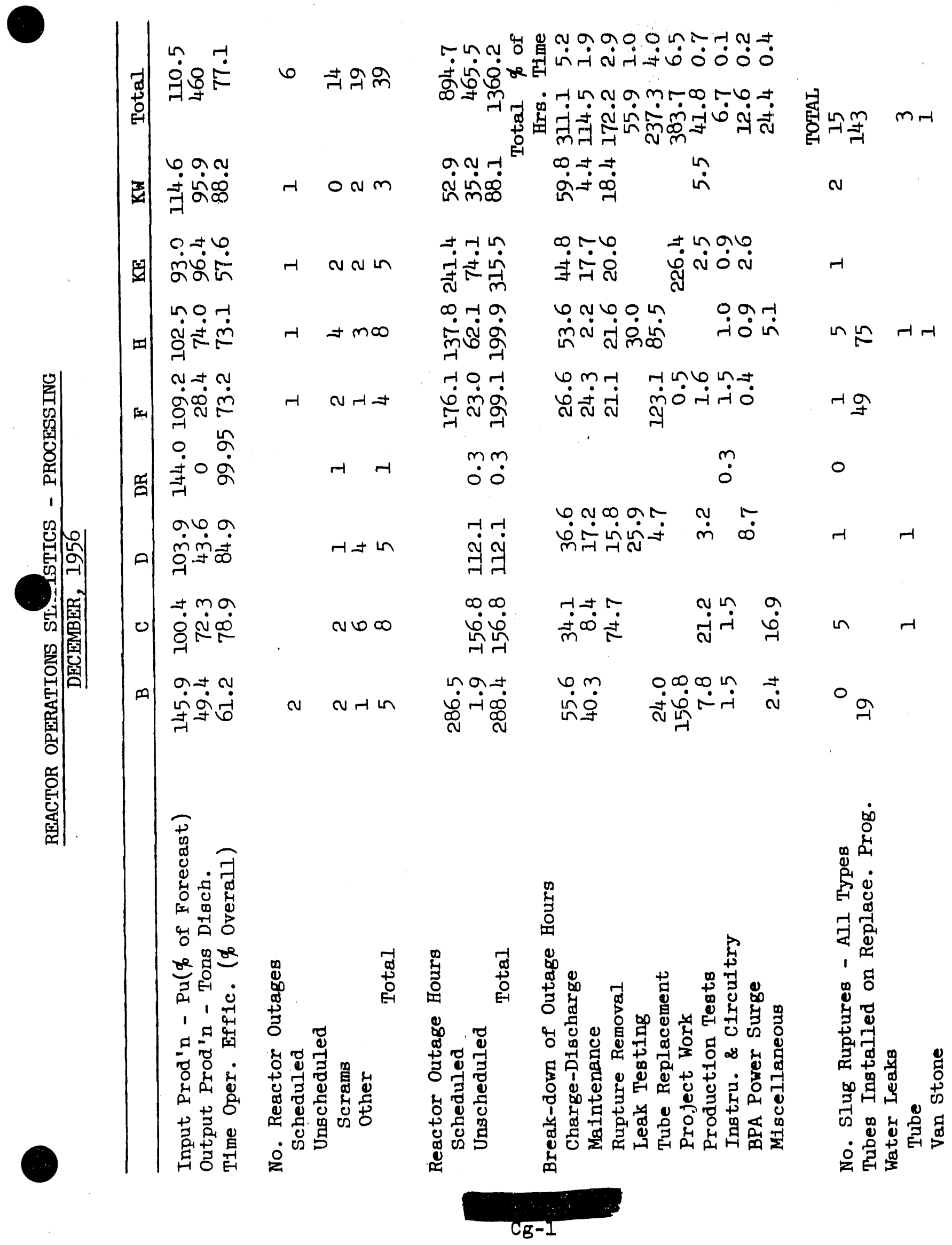



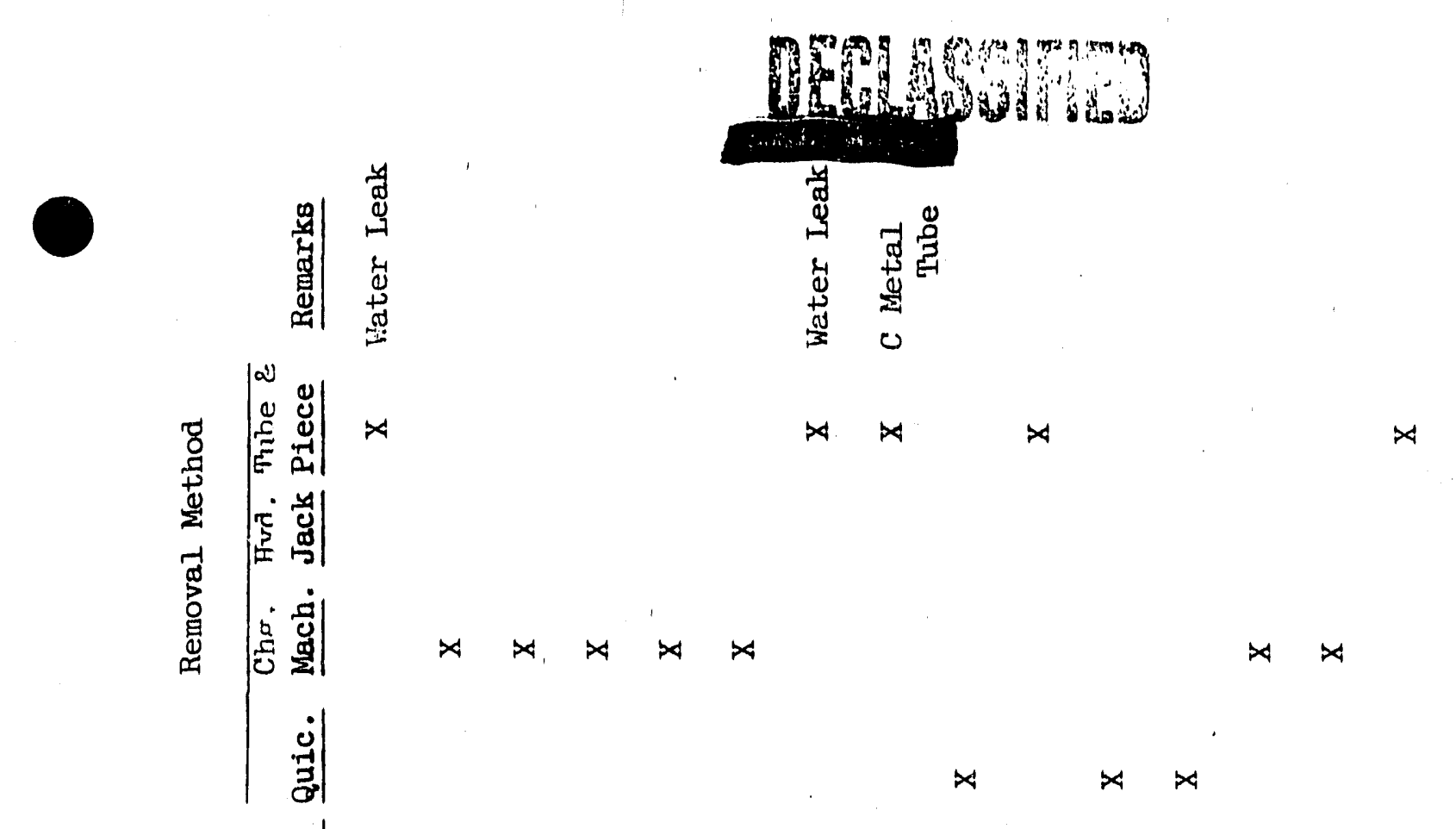

[DE]

.

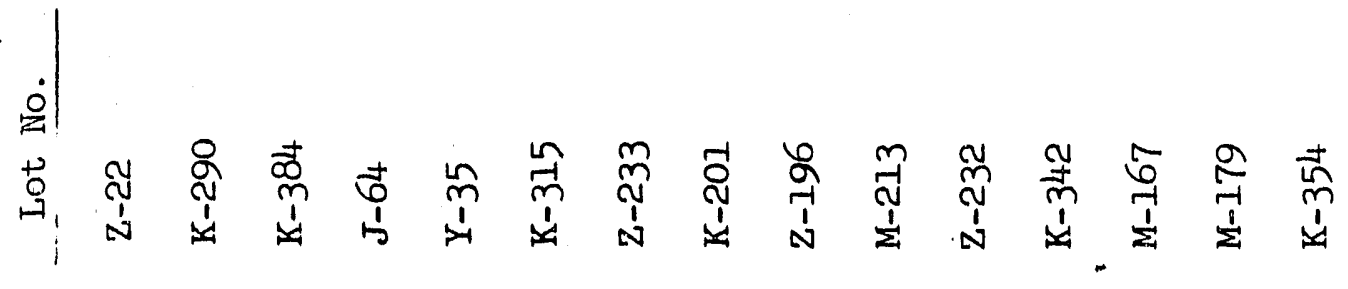

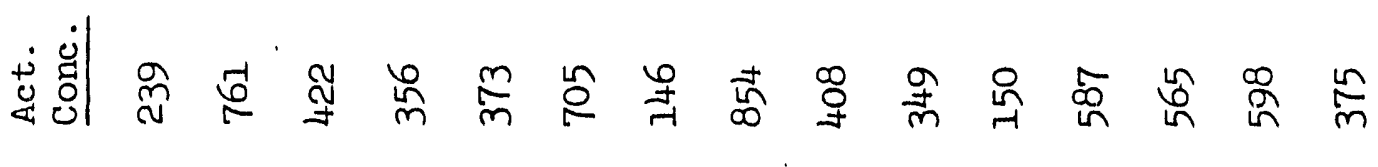

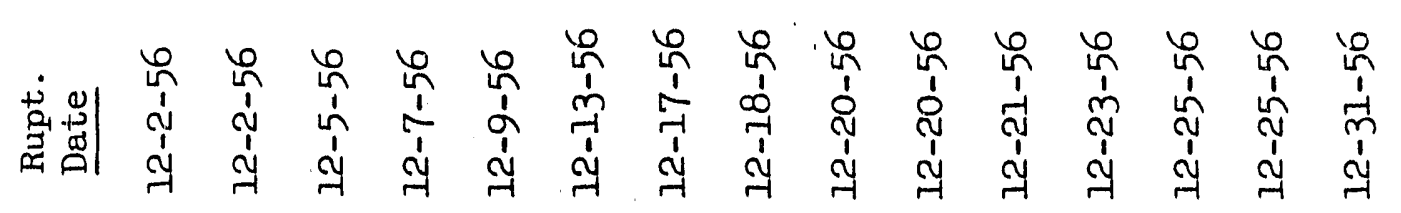

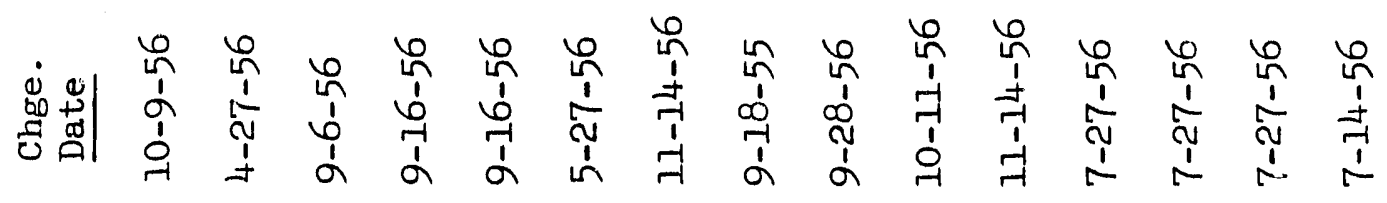
富离

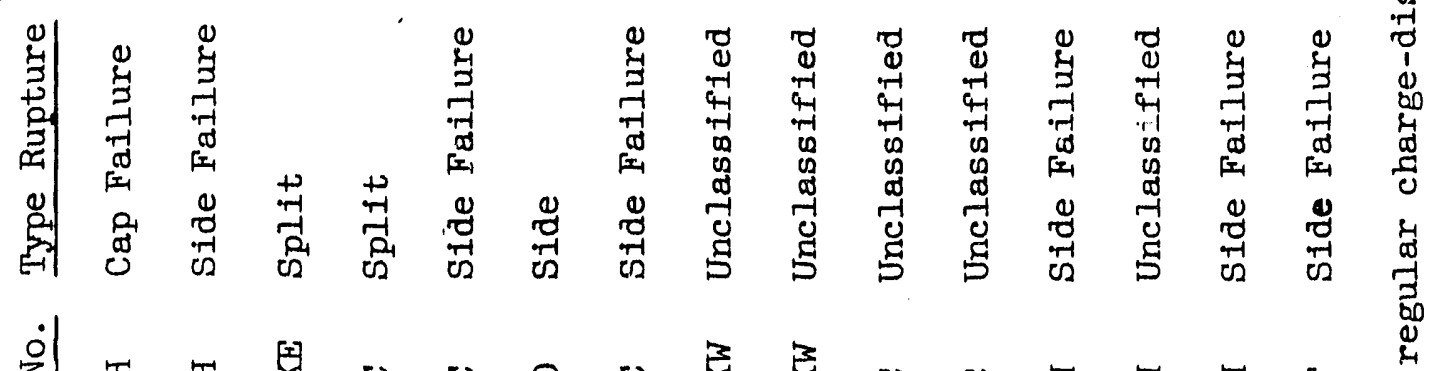

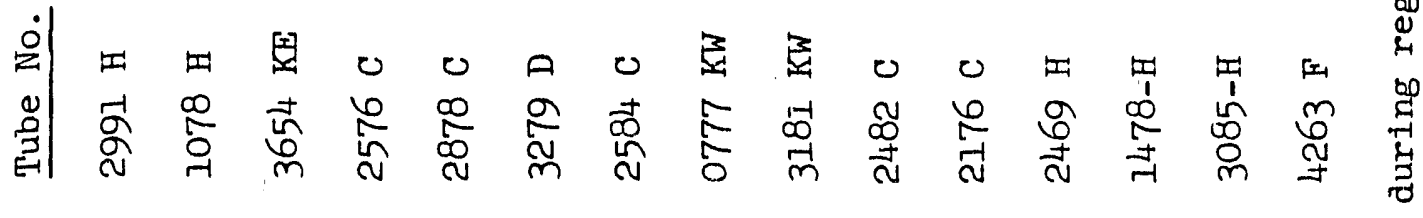

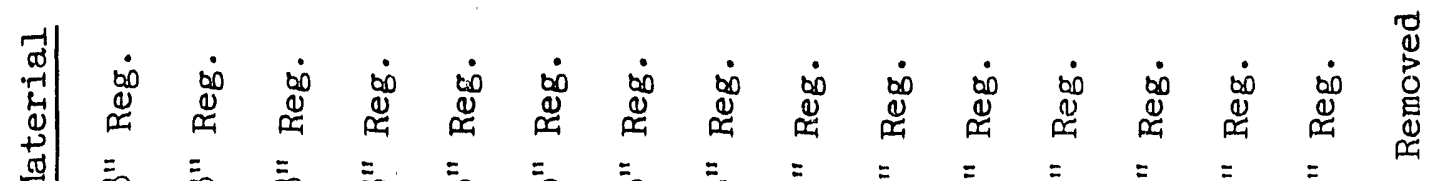

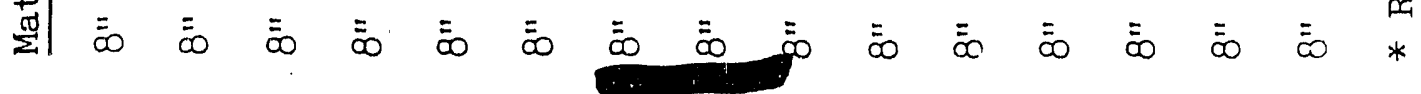




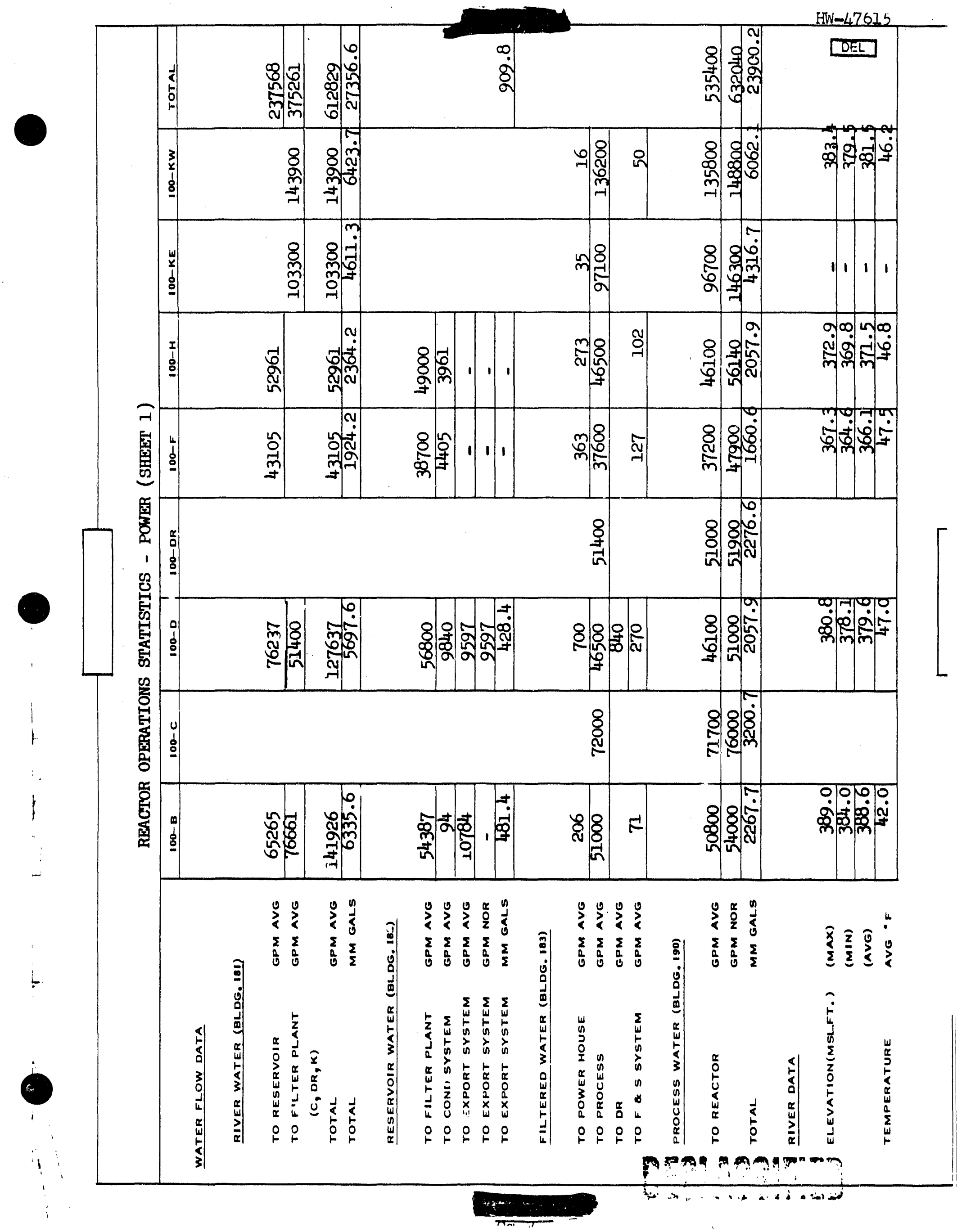


927. 0 \%

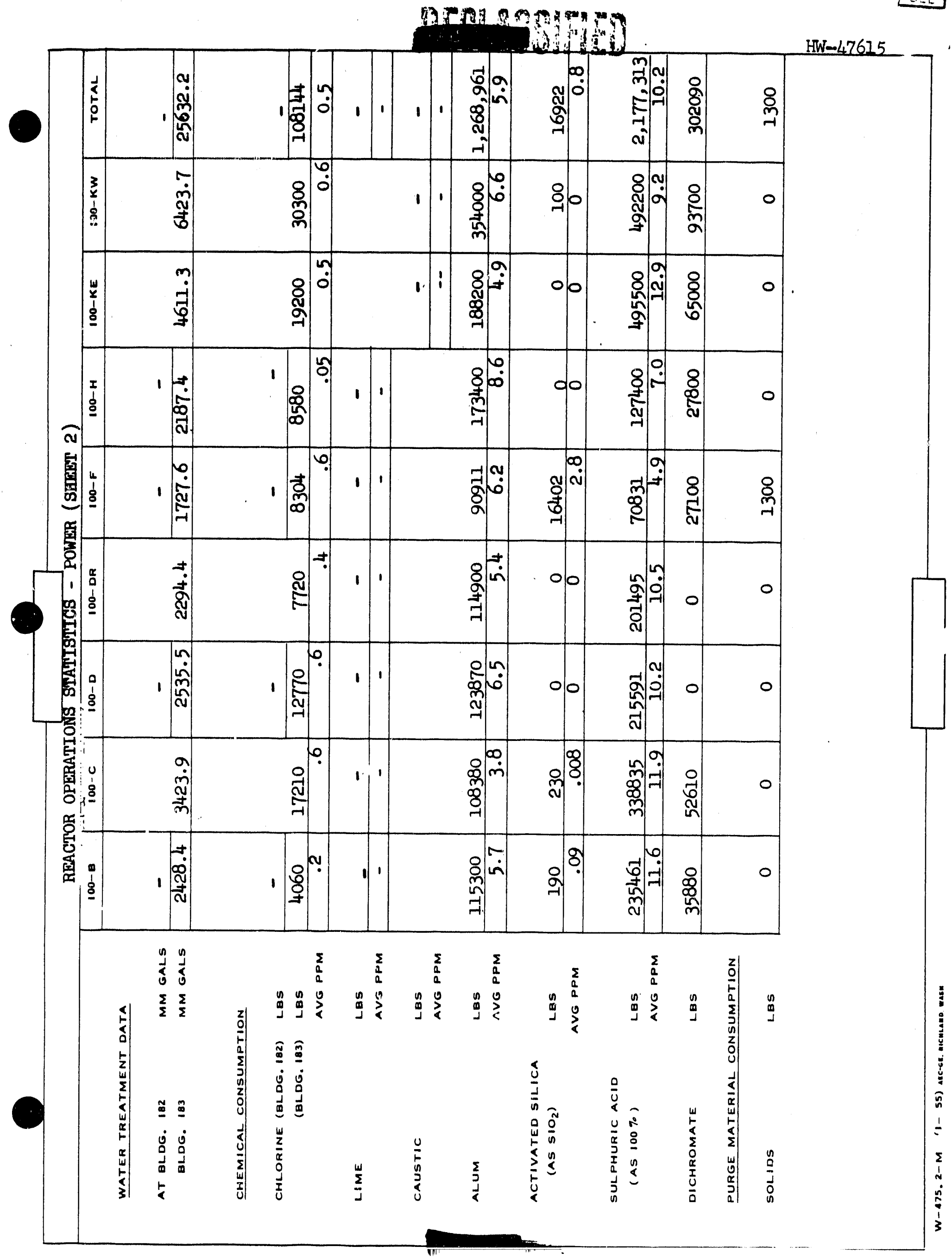




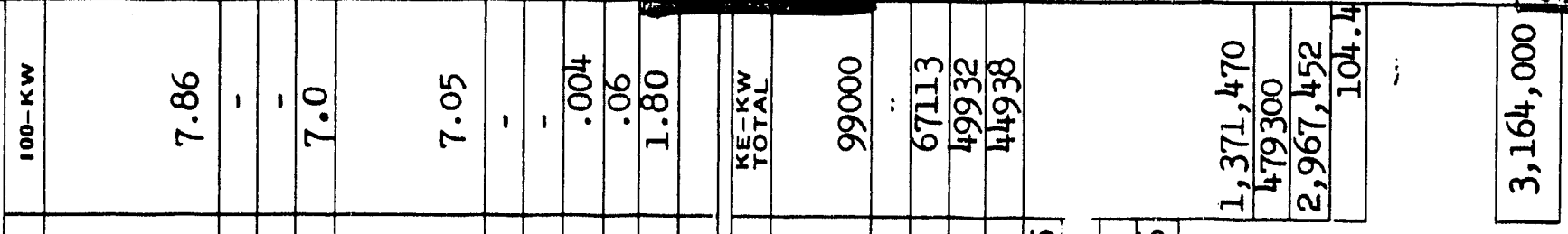

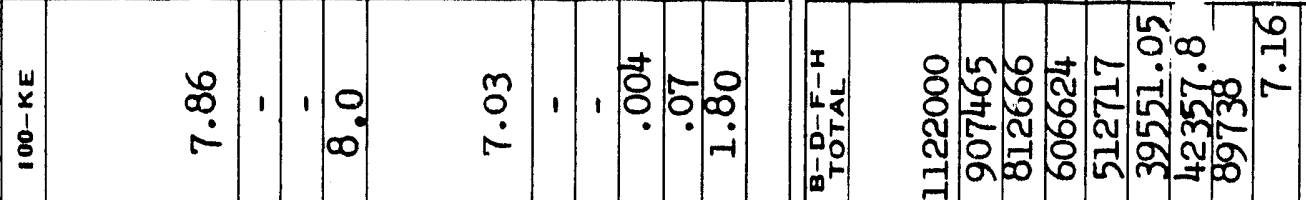

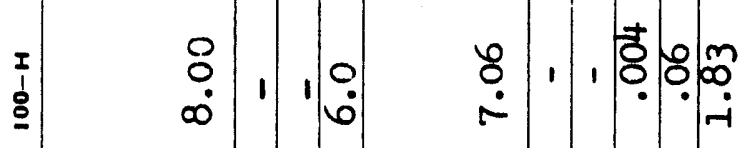

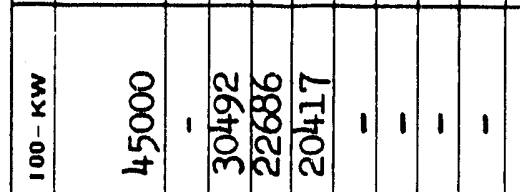

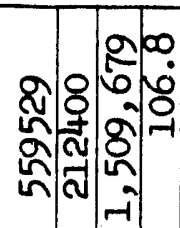

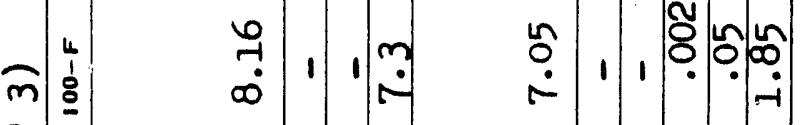

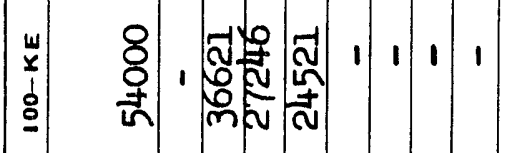

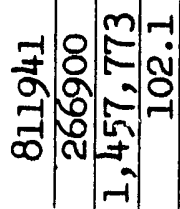

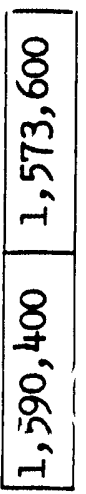

趈

论

㻖

0
1
0
0

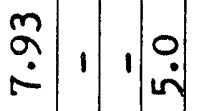

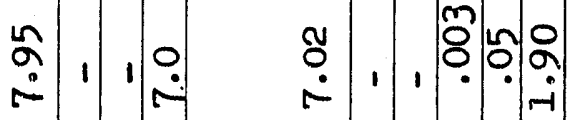

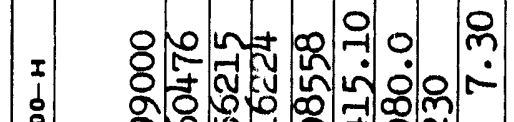

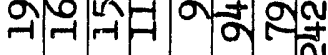

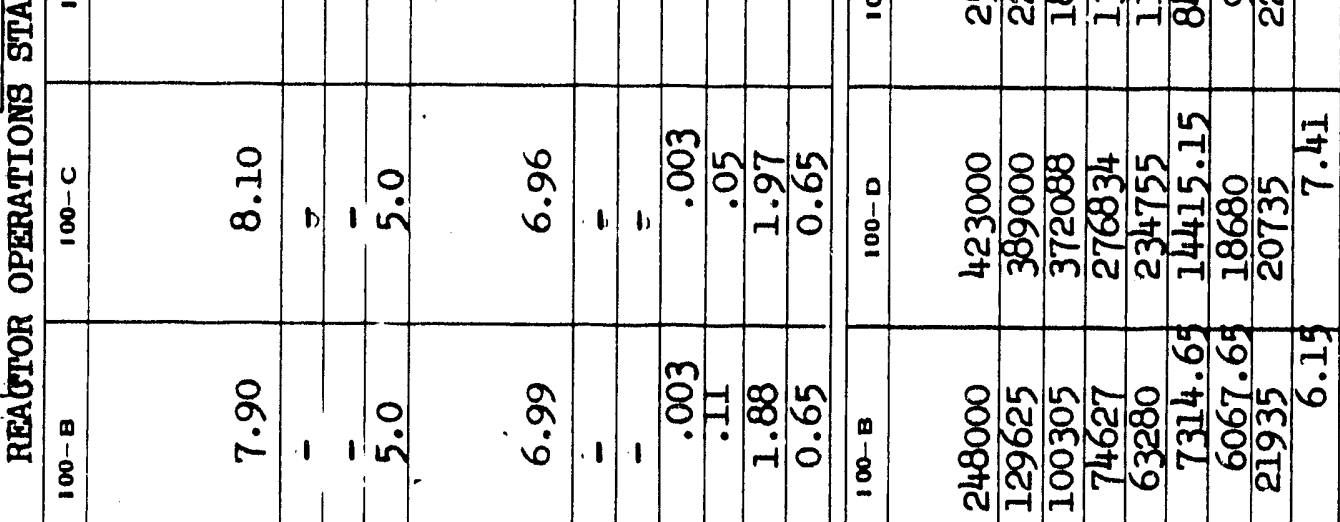

-

$\leftarrow 11 \cdot 1 \cdot \dot{1}$

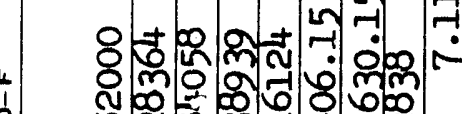

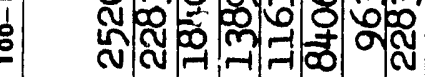

$\frac{5}{2}$

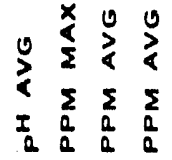

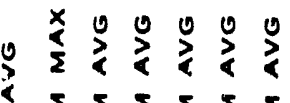

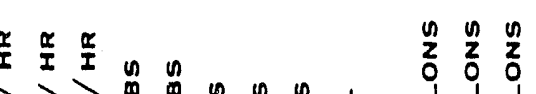

$\frac{\dot{n}}{\underline{\alpha}}$

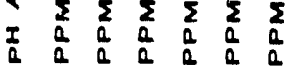

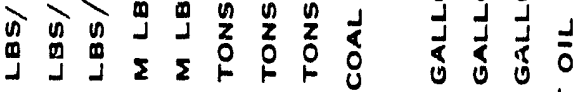

$\begin{array}{llll}0 & 0 & 0 & 0 \\ 0 & \dot{0} & 0 & 0\end{array}$

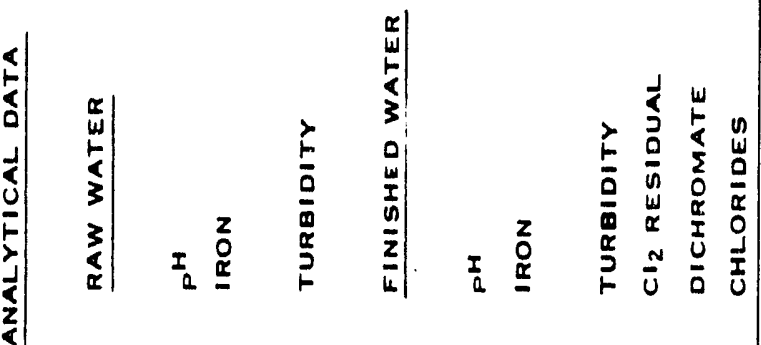

$\begin{array}{lll}x & 0 & 0 \\ x & 0 & 3 \\ \Sigma & z & 5\end{array}$

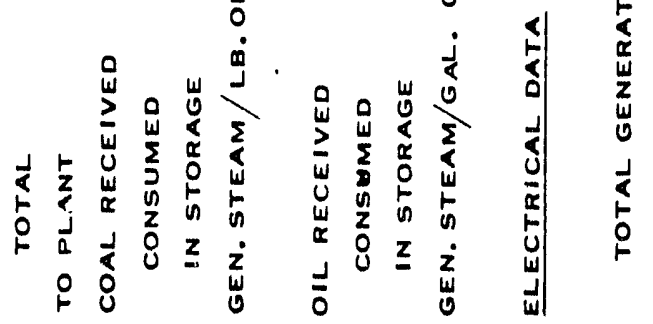




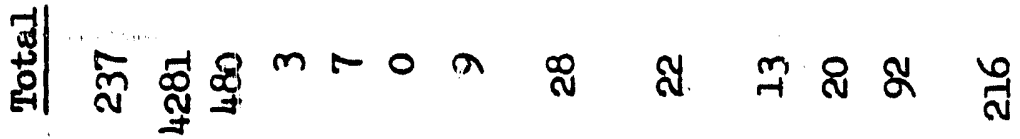

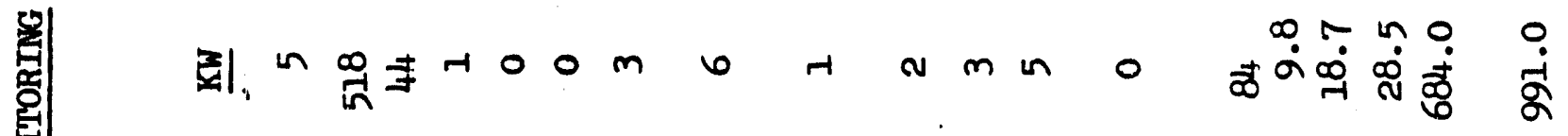

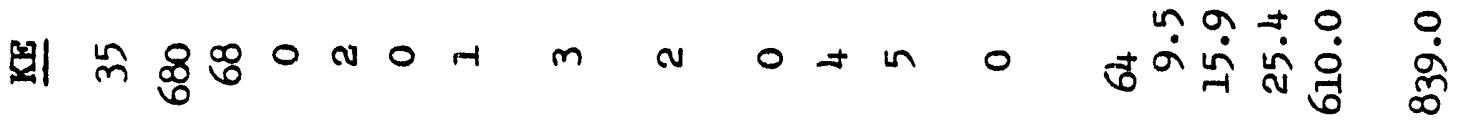
| $=$ लn ज小 舆

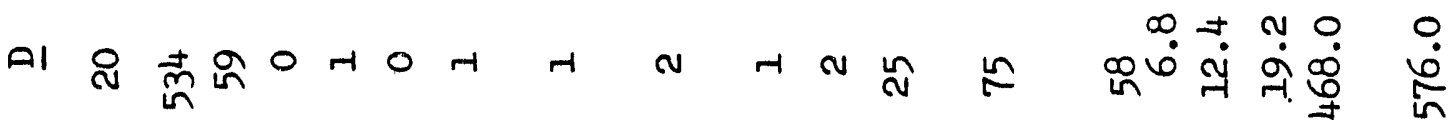

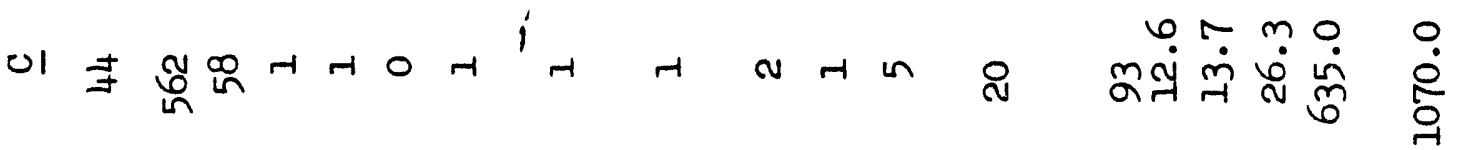

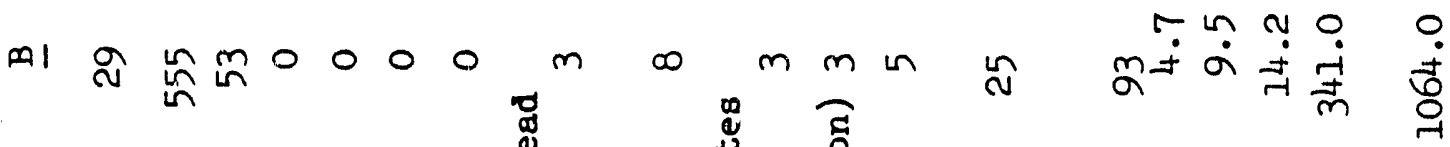

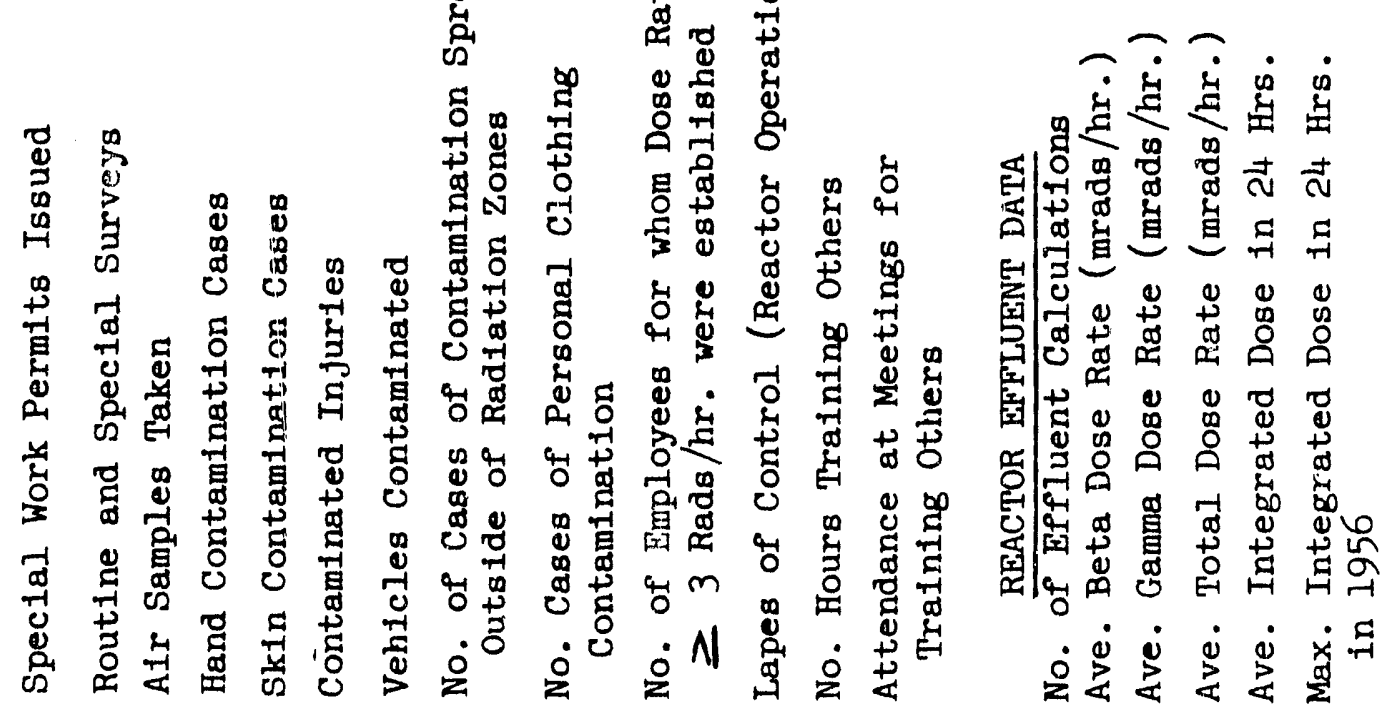

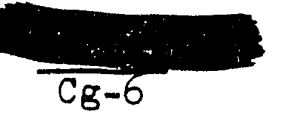




\section{PRODUCTION OPERATION}

DECEMBER, 1956

\section{RESPONSIBIIITY}

Where were no changes in assigned functions or responsibilities.

\section{FUNCTIONAL ACTIVIIIES}

A. Production Forecasting, Scheduling, and Analysis

1. Production Forecasting

Compilation of data for the five-year production forecast and for the SS allotment forecast was begun; these forecasts are scheduled to be issued the latter part of January, 1957.

2. Production Scheduling

a. Discharge Concentrations

Discharge concentrations were maintained according to the previous plan including the redefinition of rupture-prone tubes to account for the drop in inlet water temperature experienced at this time of year. A resume of individual reactor conditions is given below:

B - Anticlpated unscheduled outages following the CG-558 extended outage did not occur. The major portion of the remaining cut to the post-558 level was completed during a planned outage.

C - Continued at the previous level. A $50 \mathrm{kw} /$ tube power reduction was made late in the month after experlencling five ruptures.

D - Continued at the previous goal except that modifled goal discharging was changed from tubes above 1.35 factor to tubes above 1.20 factor to reflect lower inlet water temperatures. This change was partially accomplished in December.

$D R$ - There were no outages in December because sufflclent dischargIng had been accomplished in November to carry through unt1l the CG-558 outage scheduled early in January.

$F$ - There were no changes from pervlous plans except that modifled goal discharging was changed from tubes greater than 1.40 factor to tubes greater than 1.25 factor. As at D Reactor, this change was started.

KE - The planned concentration cut was completed during December. Cored material (1/2") Is belng discharged on the regular vartable goal basis at an average of $100 \mathrm{MWD} /$ ton above solld material. 
$K W$ - The planned concentration reduction was completed during December.

b. Process Tube Replacement

Two scheduled tube replacement outages and work at B Reactor during CG-558 resulted in replacement of 143 process tubes during December; 19 of 22 empty channels at B Reactor, 49 (Including 24 problem tubes) at $F$ Reactor, and 75 tubes at $\mathrm{H}$ Reactor.

c. Off-Plant Shipments

"C" metal shipments to Arco were completed; this included 16 casks shipped in December for a total of 24 during this series of shipments. A serles of operating difficulties at $\mathrm{KE}$ Reactor during loading on December 16 resulted in cancellation of shipment of two casks scheduled on that date. The truck that was dispatched on that date met with an accident enroute. The remaining shipments were completed using one truck, with the finel shipment on December 27.

Three casks of B metal were shlpped to Mound Laboratory. It was found that B metal with product level too low for shipment can be recharged without difficulty.

One cask of 1rradiated structural material and a box of equipment was sent to KAPL.

\section{Operations Analysis}

A study of tube replacement at H Reactor as it pertains to post-CG-558 conditions was completed and a report forwarded to the reactor manager.

B. Computing \& Machine Records

A small portion of the additional IBM equipment ordered in October, 1956 has been received. The Purchase Order for the bulk of the equipment was processed late in December, with delivery scheduled for March, 1957.

the development of a tube-by-tube data processing system for both tube eplacement and long-range production forecasting was continued during lecember. Several refinements have been incorporated, but the majority ( $?$ the improvements are dependent upon expanded machine capacity and a sharper definition of how present tube corrosion datk. should be interpristed.

BEcause of resent drastic increases in the varieties and quantities of me terials being exposed in Hanford reactors, new IBM card record forms are be $n g$ devised to permit routine machine recording of special tube charges. For merly, the number of "special" charges was relatively small, and combined written and punched card records sufficed.

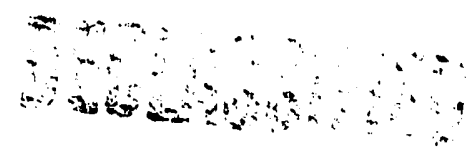


C. Reports, Statistics \& SS Accountability

1. Reports and Statistics

a. Dally Reporting

Routine processing of the I.P.D. Deily Production Report in both summary and complete forms was continued. The summary form was expended at mid-month to show efficiencies and production by the six old reactors and the two $K^{\prime} s$, instead of simply as the totals for eight reactors.

The final draft of the revised format for the Daily Production Report and the accompanyling classified document key were completed and are being prepared for advance review by interested Operations prior to 1ssuing.

b. Monthly Reporting

The Combined Report of Production and Reactor Operations for November, 1956 was assembled and issued. Included were the production summary and six pages of statistics complied by this office.

A Production Summary for December, with explanation for varlance from forecast, was prepared for management on December 26 , project: Ing production estimates and experience to month-end. Immediately following month-end a statistics sheet showing percent of production, efflclencies and outage hour breakdown was prepared for management.

Special monthly report information was assembled for personnel of the AEC-HOO (Operations Division) summarlzing plant operations and related statistics for November.

c. Production Statistics

The Chart Books deplcting reactor productions, efficiencies, and related statistics were maintained for I.P.D. and HAPO management.

Other production statistics work performed during December was as follows :

Production data, operating efflclencles, outage hours, and tube replacement information vere furnished the Flnancial Operation.

A large volume of statistical data, current and historical, was supplied to the Iive Reactor Operations.

Quality Control personnel of the Fuels Preparation Department were furnished the tube numbers and lot numbers of all stuck charges in process tubes.

Weekly reports showling daily process water flow and power level data were supplied to Radiation Protection personnel of the Hanford Laboratories Operation. 
2. SS Accountability

Contact was maintained wth the SS Accountabllity Operation In Relations \& Ut1lities, relative to the progress of arrangements for the transfer of the 100 Areas SS Accountability Unit to the Production Operation of the Irradiation Processing Department.

\section{Miscellaneous Services}

Four graphs of production data, with appropriate explanations, were prepared for inclusion in the HAPO Annual Report for 1956.

Evaluation of the impact on I.P.D. of certain Top Secret classification bases proposed by the AEC-HOO was completed on December 11. The findings were forwarded for inclusion in the overall HAPO evaluation report.

On December 19, the BPA advised that flow adjustments at Grand Coulee between then and Christmas could be expected to result in Columbia River flows at Hanford being reduced at times to the 35,000 second-feet which HAPO has stated to be the minimum permissible. This information was relayed to all interested Operations in the I.P.D.

A list of I.P.D. personnel requiring access to Top Secret data in Cat/sgory III (Combined Operations) was assembled and forwarded for HAPO consolidation. Bxplanatory notes on each individual case were included.

Miscellaneous administrat1ve functions were performed for the Production Operation. These included (1) consolidation and issuance of the November monthly report, and (2) estimation of additional office space needs on a postdormitory basis.

D. Essential Materials

Rallroad and truck shipments received in December were as follows:

$$
\begin{aligned}
& \text { Carloed shipments received for I.P. Dept. - } 641 \\
& \text { Truck shipments for I.P. Depa other Depts. - } 278 \\
& \text { Total shipmeits recelved } 1201
\end{aligned}
$$

In addition to the routine duties involved in the procurement and delivery of essential materials, the following items were included in the esential material activities during the month:

1. One additional new sulfurlc acld storage tank in the B-C Area was completed by Construction and placed in service. This extra tank will increase the storage capacity at that location from 1.0 to 1.5 months supply.

A five percent frelght rate increase on all rail shipments became effective December 26, with the increase on coal shipments being limited to $\$ .10$ per ton.

A five percent increase on HAPO's average coal shipments would have increased the rate by $\$ .22$ per ton. 


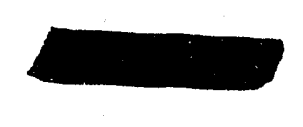

HW- 47615
$\div \quad$ DEL

3. A savings of approximately $\$ 6000$ was realized by increasing fuel oll deliveries to the 100-K Areas in the month of November. Some 500,000 additional gallons were delivered to storage before the prive increase of $\$ .019$ per gallon was effective on November 24 .

4. A strike of S.P. \& S. rallway workers during a part of December affected the N.P. rail yards in Pasco, and necessitated the rerouting of several carloads of material from the N.P. rallroad to one of the other carriers for delivery. Work was resumed after five days and no serlous delays in arrival of materials were experienced.

III ORGANIZATION AND PERSONNEL

A. Organization

There were no changes in December.

B. Force Sumary

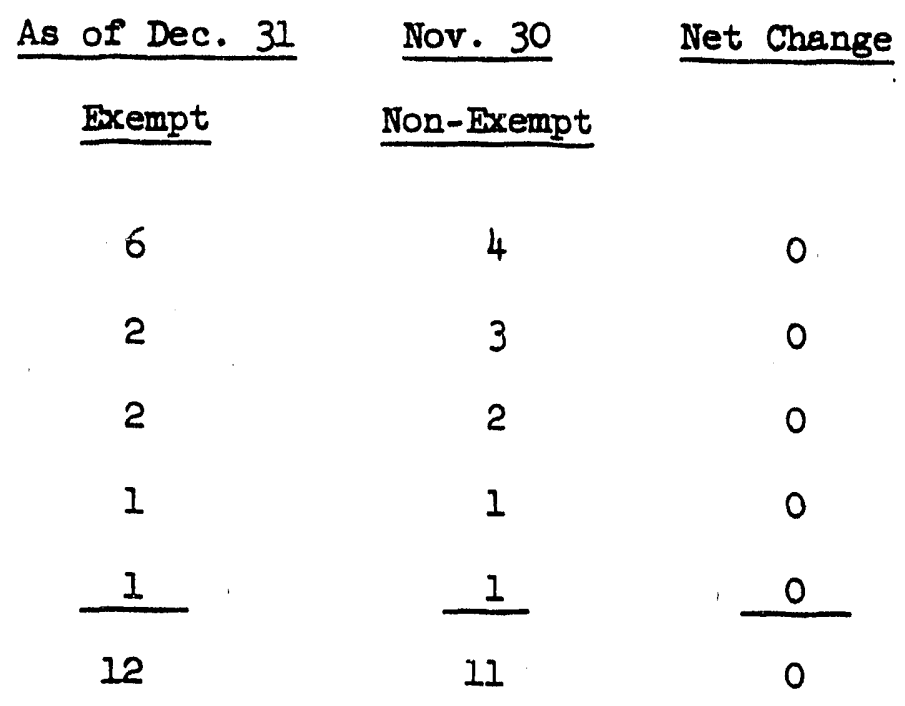

C. Safety and Security

All personnel attended a safety and securlty meeting during the month. No injuries or security violations were reported.

D. Personnel Activities

C. A. Priode attended a Feed Materials Meeting called by the AEC and held in their Washington, D. C. offlces on December 18, 1956.

There were no off-site visitors during December.

E. Non-Routine Reports Issued

None. 


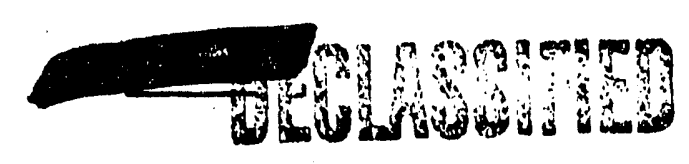

$\mathrm{HW}-47615$

TOE:

F. Inventions and Discoveries

All persons engaged in work that might reasonably be expected to result in inventions or discoveries advise that, to the best of their knowledge and bellef, no inventions or discoveries were made in the course of their work during the perlod covered by this report. Such persons further advise that, for the period therein covered by this report, notebook records, if any, kept in the course of thelr work have been examined for possible inventions or discoveries.

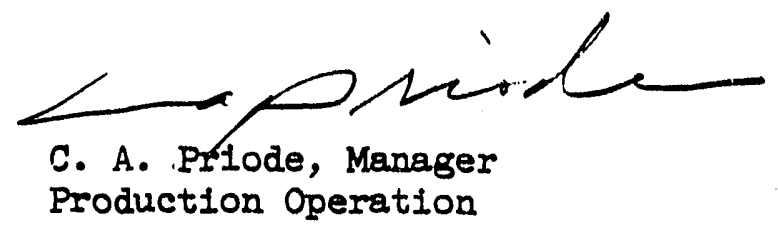

CAP :TWH : Irs 


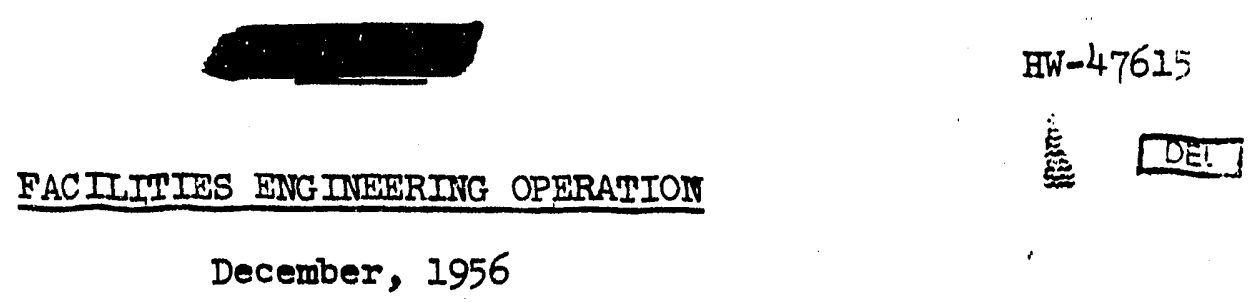

\section{SUMMARY}

Construction completion status of mefor process facilities at the end of December: was as follows:

Pro.ject Number

CA -512

$\mathrm{CA}-512$

CG-558-I

CG-558-II

CG-600
Title

100-K Area Facilities, Revisions Mos. 3 and 4 1706-KGR Rec1rculat1ng Fac1lit1es

Reactor Plant Modifications

Reactor Plant Modifications

100-C Alterations
Completion Schedule* Actuai

$\begin{array}{cc}100 \% & 100 \% \%: \% \\ 99 \% & 99 \% \\ 77 \% & 85 \% \\ 50 \% & 48 \% \\ 53 \% & 25 \%\end{array}$

Completion percentages for the design of reactor and reactor bulidings on Profect CG-654, "Advance Reactor Design", are summarized as follows:

\section{Last Month This Month}

Drawlings
Criteria
Testing
Welghted Overall

$78 \%$

$88 \%$

$47 \%$

$73 \%$

$100 \%$

$95 \%$

$51 \%$

$83 \%$

Kaiser Engineers effort for this project remains at 85 percent complete.

A transit traverse made on vertical safety rod mumber 23 in the KE Area shows alignment deviation approachlng one-fourth inch. Scratching was evident for approximately three-fourths of the observed length and one section shows evidence of galling. Deviation and erictional tests on three of the worst offending rods are being Inltiated.

Investigation of excessive vibration in the 190 to 105 Bulliding process water Iine resulted in a new design of the by-pass process water line which utilizes a serles of orifices. A test installation in DR has greatly reduced vibration, virtually eliminated evidence of cavitation, and reduced the nolse level. By-pass line modiflcations will be made in all areas.

The CG-558 outage was completed in 100-B Atrea on December 8, 1956, and the DR shutdown was scheduled for January 7, 1957. A target schedule for the outage duration in DR was established at seven weeks.

* Per certified schedule or directive completion date. * Complete except for revisions and start-up items. 


\section{RESPONSIBILITI}

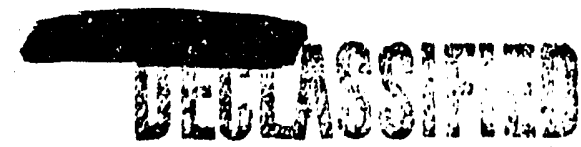

The responsibilities of the Facilities Engineering Operation remained unchanged during December.

II. ACHIEVEMEINT

A. Egaipment Experience

Investigation of the cause of increased vibration in the process water piping between the 190 and 105 Bulldings following CG-558 work was continued during the month. A review was made of the throttle valve by-pass line design with the ald of an outside consultant, Dr. H. M. Paynter. It was concluded that although no dangerous stress problem appeared to exist, It was probable that the cavitation occurring in this line at shutdown flows would result in relatively short service life for the installation. This conclision applied to the modifled design installed at B Aree as well as the original design, even though the vibration in the modified installation is notlceably reduced. A different design approach ut1lizing a series of orlfices was suggested by the conswltant. A new by-pass line design was prepared, based on this approach, and a test installation made at the DR Plant. Preliminary testing on this prototype indicates greatly reduced vibration, olitual elimination of any evidence of cavitation and reduction in noise level. It is felt that a final design based on the test installation results will provide a satisfactory solution to the problem of providing shutdown water flows. The fabrication of the revised by-pass assemblies for all pump units in DR has been started based on the avallable test data. It is planned that this same design will be installed in 911 areas, lncluding 190-B at a later date.

An investigation is being made to correct excessive friction during rod withorawal in certain vertical safety rods of the 105-KE Reactor. A transit traverse has been made on the upper 34 feet of rod number 23 which shows alignment deviations approaching one-fourth inch. The rod is scratched for approximately 75 percent of the observed length. One section shows evidence of galling. Plans include deviation and frictional effect tests on three of the worst offending rods to gather data for corrective measures and provide a comparison with rods that appear to have only normal friction.

B. Improtements

Two Inventions or discoveries were reported during the month. (See attached "Report of Inventions")

At the request of Pile Physics, a $\mathrm{BF}_{3}$ type neutron detector was supplied to $B$ Reactor for use in the post-CG-558 startup after the extended outage. This $\mathrm{BF}_{3}$ installation had the desired sensitivity for subcritical monitorIng and had reached a count rate of approximately 100,000 counts per minute before other instrments gave a positive flux indication.

Modification of the Magnetic Digital Converter recording outlet water temperature at 105-H is complete. Notable improvements are expanded range of 0 to $150^{\circ} \mathrm{C}$, elimination of moving parts in the converter, and 
simplification of the propraming relay matrix. With ininor changes, this device w1I also function with the existing clrcultry of the temperature logger at 105-B.

Scoping, development, and testing of prototypes to make the $C$ Reactor Ball 3X System operable recelved concentrated attention. A Flant and Equipment Analysis report was prepared.

The poison spline test at D reactor is proceeding satisfactorliy. Two splines were inserted to inprove flattening and have been in the pile over twenty days.

The forty foot prototype tube replacement push-pole actirator (double piston, automatic operating unit) has been fabricated and is being tested.

The test model chamber mount for the Octant Monltor System development has been completed by the 1717-H machine shop and delivered to 100-B Area for testing.

The vendor is experlencing difficulty in manufacturing thermocouple wire to conform with the new specificatlons. Mamufacturing facilities to wrap and brald glass Insulation on small leadwires are linited. Inpregation of the glass rrap with a sillcone resin resulted in a rough lumpy exterlor surface. The manufacturer has contacted A. F. Horning, Silicone Products Department, General Electric Company for technical assistance with the SR-32. They hope to resolve the problem and continue fabrication of wre insulation according to BAPO speciflcations for installation in bigh neutron activity.

C. Events Inelnencing Costs

Opward trends in labor costs on projects are apparent. These are caused by cost of Ifving increases in wages, overtime paywent requirements, and closer adherence to jurisdictionel lines. Th1s last trend of ten requires more people belng present on a specific job than has been the practice in the past.

D. Plant Improvement and Expansion

\section{Status of Project Proposals}

a. Project Proposals Approved by the Commission

CA-650, Rev. 1, Replacement, Repa1r, and/or Removal of Valve гоusés, 100-B, D, and I Areas.

b. Project Proposals Returned Onapproved by the Comotssion CA-696, Rev. 1, Cogl Car Shake-Oat, 100-B, D, F, H, and 200-W Areas.

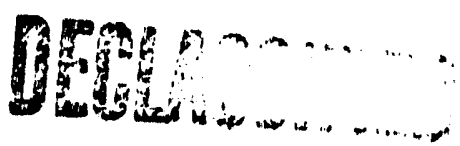


c. Profect Proposals Submitted to the Commission

CG-65I, Rev. I, Continuous Charge-Discharge - C PIIe Demonstration Unit.

d. Project Proposals in Preparation

CG-583, Rev. 2, Molsture Monitorling System for Detection of Leak1ng Process Trabes - 100-B, D, DR, F, and $\mathrm{H}$.

CG-584, Rev. 2, Molsture Monitoring System for Detection of Leaking. Process Tubes - 105-C.

CG-638, Rev. 1, Alum-Activated Silica Water Treatment Facilities Phase II, 100-B, D, DR, F, and H.

CG-642, Rev. 1, Continuous Charge-Discharge Equipment - C Reactor. CG-656, Rev. 1, Raw Water Cross-T1e - 105-C Bulld1ng. CG-669, Rev. 1, Water and Gas Leak Locating Equipment - AII 100 Areas.

CG-684, Rev. 1, Adequate Fresh Air Systems - 100-B, D, DR, F, and $\mathbf{H}$.

R-89003, Ventilation Improvements for 100-K Water Plant Facilities - 165. and 190 Bulldings.

R-89005, Increased 440 Volt Electrical Service - I89-D Bullding. R-89008, Power House Chimey Repairs - 100-B, D, H, and F Areas. R-89012, Steam Line Support Pole Replacement - 100-B, D, and F CG-714 Areas.

R-89013, Fire Protention Fac1lities - 1717-B, D, F, H, and 1704-H CA-697 Buildings.

R-89014, Organ1c Analytical and Hot Ioop Fac1lity - 1706-KE.

R-89015, Modification to Proportional Counters for Perlod Indlcation - 105-B, C, D, DR, F, and $\mathrm{H}$.

R-89016, Vertical Safety Rod Improvements - 105-KE and KW. CG-708

R-89022, Replacement of Central Viewer - 105-F Bullalng.

Renovation of the BaII 3X System - 105-C.

R-8902I, Lunch and Locker Room Improvements - 100-B, D, and F Areas . 
2. Plant Engineering

a. Maintenance Program

The overall progress of the Productive Maintenance Program is satisfactory and on schedule. The Productive Malntenance Manual was distributed on December 10. All work has been scheduled in the 100-B and 100-C Aress with the exception of the 190-B Annex. AII productive maintenance scheduling for December has been completed for the process buildings in the 100-I Area. Check sheet forms for use with the system are being designed.

b. Standards Englneering

A meeting of Irradiation Processing Department engineers was held on December 19, 1956, to review the Engineering Standards program as it is being developed. Members appolnted to this group will review the overall BAPO standards in the mechanical, electrical, instrument, and architectural-civil flelds.

c. Assistance from Principal Englneers and Others within FEO

Weather conditions resulted in a recurrence of power line icing conditions in the vicinity of the 107 basins. Service was interrupted in the 100-D Area due to the breaking of the power Iines. Assistance was requested to determine the action to be taken to alleviate the icing conditions.

A study of the ventilation conditions in 165-KE and $K W$, and $190-\mathrm{KE}$ and $\mathrm{KW}$, was undertaken to determine the scope of work required to bring these facilities to an acceptable standard. The recomendation proposed Involves installation of exhaust fans in the roof of 165. A Plant and Equipment Analysis Report is beling circulated for approval.

The $13.8 \mathrm{kv}$ staged system tests performed on November 28 at the 190-B Annex Indicated that system stabllity is better than Indicated in the conservative Calculating Board Studies made at Schenectady in 1955.

Engineering studies have been inltiated on 1tems proposed for F1scal Year 1959 Plant Acquisition and Construction Budget whlch fall within the responsibilities of Process Design Operation. Budget study fund requirements are currently being estimated and arrangements being made for utilizing assistance from Construction Engineering Operation.

d. Suggestion Evaluation

One hundred and seven suggestions were recelved during the month. The eveluation back-log Increased from 312 at the end of November to 366 at the end of December. Elghteen awards totaling $\$ 1,610$ in payments were approved. 
e. Drafting Services

The sumary of drafting services provided is as follows:

Drawlings Involved Total Number

\author{
New Engineering Drawings \\ Des1ga Changes \\ As-Bullalng \\ Sketches
}

Blueprint File Service

Drawlings and BPFs Added - 97
Drawlings and BPFs Refiled -429
Drawings and BPFs Retired - 37
Customers Serviced - 218

3. Design and Development

Preliminary design work is belng pursued on two FY 1957 items which are not approved projects. (Installation of VSRs, $\mathrm{KE}$ and $\mathrm{KW}$; and VSR Improvements, All Reactors) A project proposal (CG-708) was prepared for the instailation of additional VSRs at the K Reactors and necessary departmental approvals obtained during the month. Project Representatives have been appointed by the Design Council. Drafts of the Design Criteria and three scope drawings have been 1ssued to the Project Representatives for comment. The design test of a six-inch diameter rod drive cylinder has been completed. Data indicate that an air-accelerated rod design can be used for unaccelerated operation with only minor adjustments of relief valve settings and oriflce sizes. This will form the basis for design of the K Reactor installation. Certain information developed on this project is applicable to CG-709, VSR Improvements, All Ractors.

Information was developed during the month in answer to two general questions which have been raised concerning HAPO by-product power reactor concepts. These are: (a) effect of size on capital cost and operating characteristics; and (b) effect of design bases on reactor characteristics, e.g., optimization for plutonium production as opposed to optimization for power production. In answer to question (a), a document has been written covering studies which were made of the Supplementary Production Reactor concept at four different thermal power ratings: $2400 \mathrm{MW}, 1800 \mathrm{MW}, 1700 \mathrm{MW}$, and $600 \mathrm{MW}$. Included are estimates of both capital and operating costs. Preliminary conclusions are that down to $1200 \mathrm{MW}$ the penalty in performance is not excessive, but for smalier sizes, the product untt cost, including capital charges, climbs so rapidiy that economically competitive operatior (with existing plutonium producers) probably cannot, be attained. Information in answer to question (b) was also developed and put in form of specific illustrative examples. However, no formal documentation is planned at this time. 
A preliminary study of the layout of the reactor building for the Supplementary Production Reactor was initiated. It is possible that this building will be somewhat different from that used at 105 ok due to the fact that the front face may not be approached at all during reactor operation. It may also be desirable to incorporate the primary heat exchangers, combined water plant and reactor control room, and much of the coolant system inside the 105 Building. Analytical studies to deterulne emergency coolant requirements for the Supplementary Production Reactor (or any high pressure recirculating reactor) have continued. The first type of occurrence considered was the rupture of one of the front manffolds. Initial calculations indicate that a matter of minutes rather than second.s would be available for an emergency source of coolant to be brought in.

Studies were continued on various types of water manifolding for byproduct power reactor designs. The studies include consideration of an individual connector ccncept and a multiple crossheader system of manifolding as possible methods of supplying the increased flows which result from lower delta Ts and higher tube powers. A feasibility report on the individual connector system was issued during the month Indicating that same $\$ 30,000$ w1ll be required to develop and test components for this type of water manifolding. A study has been made to evaluate fabrication tolerances for the water wall manifolding concept. As the tolerances are relaxed, the water wall must be moved away from the shield. This change in location adds to the length of zirconium process tubes and is reflected in increased capital costs. Curves showing the effects of various fabrication tolerances are belng prepared and this study will be documented.

Drawings SK-1-6I70 and SK-1-6I7I were prepared showing the calandria, graphite, and shielding of the Plutonium Recycle Program Reactor being scoped by the Laboratories Operation. Work sheets were made for studying the layout of the removable sections of the shield and for designing of the calandria. Descriptions of these components were written for inclusion in the preliminary seope document. Comment drawings and a preliminary witten description of the shim control equipment have been isoued for comment.

A protutype poison colum control facllity was installed in B Reactor during the CG-558 shutdown and is ready for testing during operations. Changes are planned in the use and arrangement of electrical components to Increase rellablitty since minor troubles were encountered during acceptance testing.

Modification of the hot balf separator has increased its sensitivity to a separation threshold of less than $100 \mathrm{mrad} / \mathrm{hr}$. at ole foot. This is ten times better than the orlginal design limit of one $\mathrm{R} / \mathrm{hr}$. . and is at a polnt where further sensitivity increase probably will require major design changes rather than simple modifications. Operations has been requested to supply a minimus separation level acceptable by all Areas. 
4. Project Maintenance

November December

a. Active major work orders

19

19

b. Individual Installations

87

70

c. Unexpended labor dollars

$\$ 890,000 \quad \$ 947,000$

5. Status of Approved Profects 
Pro.ject No.

Page No.

CA-512

CA- 512

$\mathrm{CA}-548$

CG-558

CG-558

CG-579

CG-583

CG -584

C.G-600

CA-615

CG-616

CG-618

CG-622

CG-638

CG-642

CA-649

CA-650

CG-65I

CG-654

CG-656

CG-663

$C G-565$

CG-666

CG-667

CG-669

CG-674

CG -678

CG-684

CG-689

CA-690

CG-694

CA-702

$A E C-160$
1952 Hanford Expansion - $100 \mathrm{~K}$ Area Facility

1952 Hanford Expansion - 100-K Area Facillty - 1706-KER

D-10

New VSR Test Tower

Reactor Plant Modifications for Increased Production - Ph. I

Reactor Plant Modifications for Increased Production - Ph. II

Effluent Water Monitoring Improvements - 100-C

Molsture Monitoring System for Detection o: Leaking Process Tubes - 100-B, D, 'DR, F, and H Areas.

Molsture Monitoring System for Detection of Leaking Process Tubes - 105-C

100-C Alterations

D-II

$D=12$

$\mathrm{D}-12$

D- 13

$D-14$

D. 14

$\mathrm{D}-15$

Mechanfcal Maintenance Shop Centralization - 100 Areas

$D-15$

$D-16$

Installation of Acid Feed Equipment - 100-B, D, DR, F, and H D-16

Replacement of Steam Iine Support Poles - 100-B, $D$, and $F$ Areas $D-17$

Replacement of Discharge Chute Liners - 100-B, D, and F Areas D-17

Alum Activated Silica Water Treatment Facility - Phase II D-18

Continuous Charge-Discharge Equipment - C Reactor

$D-18$

FY 1956 - Water Tank Replacement

$\mathrm{D}-19$

$\begin{array}{ll}\text { Replacement, Repair, and/or Removal of Valve Houses } & D-19 \\ \text { Continuous Charge-Discharge Equipment - "C" Pile } & D-20\end{array}$

Advance Design - Reactor Plant

$D-21$

Installation of Raw Water Cross-Tle - 105-C

$\mathrm{D}-22$

Steam Auxiliaries for the 165-K Steam Generators

$D-23$

Metal Loading Facilities - 100-B, D, DR, F, and H Areas

Zone Temperature Monitoring - 100-B, C, D, DR, F, and H Areas

$D-23$

$D-24$

Improved Space Utilization - 105-B, D, and $F$ Bulldings

$D-24$

Water and Gas Ieak Locating Equipment - AII 100 Areas

$D-25$

Water Plant Component Test Ioop - Building 1706-KE

$D-26$

Laboratory Facilities for the Special Irradiation Studies

$D-26$

Adequate Fresh A1r Systems - 105-B, D, DR, F, and H Areas

$D-27$

SIug Saw and Etching Equipment - 105-C Building

$D-27$

Roof Repairs - 190-D, F, and 186-D Buildings

$D-28$

$D-28$

$D-28$

Relocate Dormitories - 100-I Area

D-29 


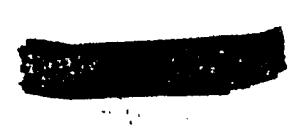

\section{HW- -476}

CA-512, Rev. No. 5 - 1952 Hanford Expansion - 100-K Area Facil1ty

Project Engineer: C. E. Love

Welghted Scheduled Actual

Detailed Design:

Not Scheduled $99 \%$

Physical Performance:

Total Progress:

Fixed Price:

Construction operation:

Project Maintenance:

Average Manpower:

Fixed Price:

Construction Operation: 6

Project Malntenance: 2

$\begin{array}{rll} & 100 \% & 85 \% \\ 8.72 \% & 100 \% & 89 \% \\ 43.30 \% & 100 \% & 69 \% \\ 47.98 \% & 100 \% & 96 \%\end{array}$

$\begin{array}{llr} & \text { Approx. Accumulated Mampower: } \\ 9 & \text { Flxed Price: } & 800 \\ 6 & \text { Construction Operation: } & 6,050 \\ 2 & \text { Project Maintenance: } & 4,760\end{array}$

Directive Completion Date: Nay 1, 1955*

Beneficial Use Date: $\quad$ KTS - February 8, 1955*

$\mathrm{KW}$ - December 5, 1954*

Authorized Funds:

$\$ 155,070,000$ - GE \$26,330,000 -

Estimated Cost: AEC $\$ 128,740,000$

$\$ 155,070,000$

Performance percentages and narrative apply only to exception items covered by revisions 3,4 , and 5 of the project.

The fabrication of the new discharge chute gates for the 105-KE Area has been completed. The installation was partially performed during KER outage in 105-KE. This work has not been scheduled for 105-KW.

The procurement for Gamm Monitoring System is not firm. The conirrol system (H6P-1502) has been recelved, but dellvery of the spectrometers (H6P-13484) cannot be scheduled.

The testing of the prototype model was performed during the week of December 10, but test results are not available.

The Installation of Beta Monitoring System by Construction Operation is proceeding. The mechanical equipment (H6P-1517) was shipped December 12, 1956.

Contract AT (45-I) II57 Acld Feed System - 100-K

The installation of condult rans is complete. Setting of floodlight support poles will be complete by the end of this reporting period.

* The directive completion date of May 1, 1955, has never been changed, although there has been unofficial agreement to use February 28, 1957 as the completion date for the exceptions listed in modification No. 5 . The beneficial use dates of December 5, 1954, for 100-KW, and February 8, 1955, for 100-KE, are actual, with exceptions still being carried out. 


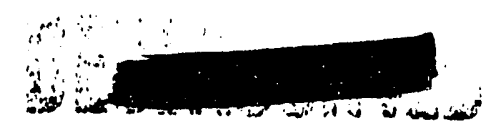

CA-512, Rev. No. 5 - 1952 Hanford Expansion - 100-K Area Facility (Con't)

The shop fabrication of piping is continuing. Installation of piping supports and gravity feed trough in the building is proceeding. The acid head tanks are scheduled for delivery this month, but the storage tanks are not scheduled for delivery until late January. This will delay completion of job.

\section{Contract AT(45-1) 1137 1706-KE Modif1cat1ons}

The air compressors and pump drain have been completed and tested. The Dowtherm System cannot be tied in until the KER outage is complete since the Dowtherm System circult breaker will be used for KER testing.

The partitions were shipped November 30, 1956, and installation is scheduled to start after the KERR outage.

CA-512 - 1952 Hanford Expansion - 100-K Area Facilities - 1706-KER Recirculation Loop

Project Engineer: C.E. Iove

\section{Welghted Scheduled ActuaI}

Physical Performance:

Total ProgresB:

Fixed Price:

Construction Operation:

Pro.ject Maintenance:

$\begin{array}{rrr}57 \% & 99 \% & 99 \% \\ 42.5 \% & 100 \% & 100 \% \\ .5 \% & 99 \% & 99 \% \\ 98 \% & 99 \%\end{array}$

Average Manpower:

Fixed Price:

0

Construction Operation: 5

Project Malntenance: 1

Approx. Accumulated Mampower:

$\begin{array}{lr}\text { F1xed Price: } & 5,200 \\ \text { Construction Operation: } & 3,175 \\ \text { Project Maintenance: } & 95\end{array}$

Directive Completion Date:

Mry 1 ; 9955 .

Beneficial Use Date:

November 15, 1956*

Authorized Funds:

Estimated Cost:

$\$ 2,430,000$ - GE $\$ 1,880,000$ - AEC $\$ 550,000$

$\$ 2,430,000$

Construction Operation Forces are contlnuing to correct Design exceptions and changes. Tle-in work to the $\mathrm{KE}$ Reactor was completed December "2O, 1956.

* Research and Engineering assumed beneficial use of the out-of-pile portion of the faclilty October 25, 1956, and since then has been conducting start-up and ran-in tests on this portion. Beneficlal use of the complete facility was obtained December 2I, 1956. 


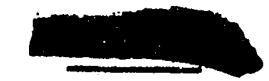

- HW -47615 DI:

CA-548, Rev. No. 2 - New VSR Test Tower

Project Englneer: J. C. I. Chatten

Welghted Scheduled Actual

Deta1led Design: $100 \% \quad 100 \%$

Physical Performance:

Total Progress:

Fixed Price:

$100 \%$

$11 \%$

$11 \%$

Average Mampower:

Fixed Price: 0

Approx. Accumulated Manpower:

Fixed Price: 38

Directive Completion Date:

Beneflclal Use Date:

Apr11 1, 1957

Authorized Funds:

Estimated Cost:

Not Established

$\$ 125,000$ - GE $\$ 10,500$ - AEC $\$ 114,500$

$\$ 125,000$

AII phases of job are proceeding satisfactorily.

CG-558 - Reactor Plant Modiflcations for Increased Production - Phase I Project Engineer (Reactor): R. K. Smith

Pro.ject Englneer (Water Plant): J. P. Langan

Weighted Scheduled Actual

Detajled Design:

$100 \% \quad 100 \%$

Physical Performance:

Total Progress:

Fixed Price:

Construction Operation:

Pro.ject Maintenance:

$\begin{array}{rll} & 87 \% & 85 \% \\ 40.82 \% & 99 \% & 99 \% \\ 51.28 \% & 79 \% & 73 \% \\ 7.88 \% & 77 \% & 88 \%\end{array}$

Average Manpower:

Fixed Price:

50

Construction Operation: 495

Project Malntenance:

Approx. Accumilated Manpower:
Fixed Price:
Construction Operation:
Project Maintenance:
7,090

Directive Completion Date: December 15, 1957

Bereflclal Use Date: July 12, 1957

Authorlzed Funds: $\$ 25,900,000$

Estimated Cost: $\quad \$ 25,900,000$

The decision by the Design Counc1l to 1nstall ofl purification equipment in each 190 Building pump room annex was approved by the Comnission.

Field Ilaison activities were continued by Design Englneers. Acceptance testing of 100-B Area was successfully completed in December. The acceptance tests indicate that operation of the water plant and reactor equipment installed by this project met design nquipements satisfactorily.

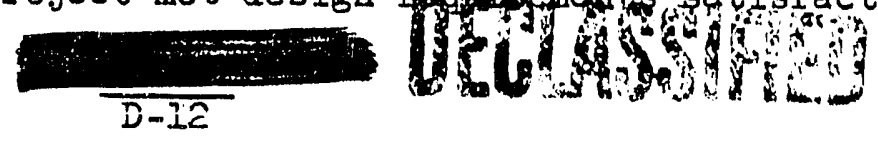




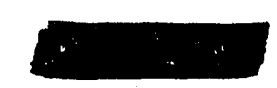

$\frac{\text { CG-558 - Reactor Plant Modifications for Increased Production - Phase I }}{(\text { Con't) }}$

Since completion of the acceptance testing the 100-B Area has been started up and is operating satisfactorily. The major outage work in 100-B Area was completed December 8, 1956.

It became necessary to make several design changes during the 100-B Area outage. These changes are being studied for possible application in the other areas.

The major outage in 100-DR Area is scheduled for January 7, 1957, and the target schedule for the duration is seven weoks. The pre-outage work in DR has progressed rapidly. The 190-DR Annex was accepted as complete December 6, 1956.

The 190-B Office addition work is proceeding, with the structural steel erected, siding and interior insulation board installed, and the installation of the roof deck started.

CG-558 - Reactor Plant Modifications for Increased Production - Phese II Project Engineer (Reactor): R. K. Smith

Project Engineer (Water Plant): J. P. Langan

Weighted Scheduled Actual

Physical Performance:

Total Progress:

Fixed Price:

Construction Operation:

Project Maintenance:

$\begin{array}{lll} & 73 \% & 48 \% \\ 56.00 \% & 97 \% & 63 \% \\ 40.81 \% & 39 \% & 29 \% \\ 3.19 \% & 39 \% & 34 \%\end{array}$

Average Manpower:

Fixed Price: $\quad 116$

Construction Operation: 119

Project Maintenance:

116
119

Approx. Accumulated Manpower:

$\begin{array}{lr}\text { Fixed Price: } & 27,463 \\ \text { Construction Operation: } & 20,004 \\ \text { Project Maintenanco: } & 387\end{array}$

Directive Completion Date: February 28, 1958

Beneficial Use Date: November 29, 1957

Authorized Funds: $\quad \$ 11,200,000$

Estimated Cost: $\$ 11,200,000$

There has been very I1.ttle work by Congtruction Operation and Project Maintenance forces because of the work on Phase $I_{0}$ 
CG-579, Rev. No. I - EPfluent Water Monitoring Improvements - 100-C

Project Englneer: J. W. Hedges

Welghted Scheduled Actual

Phystcal Performance:

Total Progress:

Project Walntenance:

$\begin{array}{lll}100 \% & 90 \% & 98 \% \\ 90 \% & 98 \%\end{array}$

Average Nemporrer:

Project Malntenance: I

Approx. Accumulated Mampower:

Project Ma1ntenance: 1,380

Directive Completion Date: February 1, 1957

Beneficlal Use Date: November I, 1956*

Authorlzed Funds: $\quad \$ 168,000$

Estimated Cost: $\quad \$ 168,000$

Project intenance is "touching up" instrument panels and working on "punch IIst" Items.

* The gamma monftoring system in 105-C was placed in beneficial use on November 1, 1956.

CG-583, Rev. No. I - Mo1sture Monitoring System for Detection of Leaking Process Tubes, 100-B, $D, D R, F$, and H Areas

Project Englneer: H. A. Zwelfel

Weighted Scheduled Actual

Detalled Design:

$100 \%$. $\quad 100 \%$

Physical Performance:

Total Progxess:

Project Ma:intenance:

$\begin{array}{lll} & 98 \% & 86 \% \\ 100 \% & 98 \% & 86 \%\end{array}$

Average Mampower:

Profect Malntenance: 1

Approx. Accumalated Maupower:

Project Maintenance: 3,510

Directive Complet1on Date: December 31, 1956

Beneflc1al Use Date: B - Apr11 20, 1956; D - May 21, 1956

Authorized Funds: \$293,000

Estimated Cost: $\quad \$ 293,000$

Gas booster pumps being tested at 105-B have thus far performed sat1sfactorily. It now appears that the eight additional pums can be placed on requisition bj January 2, 1957.

A project revision extending the physical completion date to June 1 , 1957, is beling prepared by Englneering Auxiliaries Operation. 


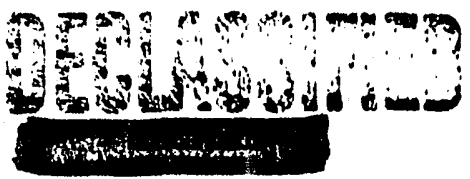

CG-584, Rev. No. I - Moisture Monitoring System for Detection of Leaking Process Tubes - 105-C

Project Englneer: H. A. Zwelfel

Weighted Scheduled Actual

Detalled Design:

$100 \%$

$100 \%$

Physical Performance:

Total Progress:

Project Ma1ntenance:

$\begin{array}{lll}96 \% & 89 \% \\ 100 \% & 96 \% & 89 \%\end{array}$

Average Manpower:

Project Maintenance: 3

Approx. Accumulated Manpower:

Project Malntenance: 810

Direct1ve Completion Date: December 31, 1956

Authorized Funds:

$\$ 72,000$

Estimated Cost:

$\$ 72,000$

Electrical forces have completed the pulling of the wire into the Control Room. Instrument forces are making the connections to the segmental recorder.

The Dewcels have been cleaned and recoated.

A project revision extending the physical completion to March 1, 1957, is being prepared by Englneering Auxilfarles Operation.

CG-600, Rev. No. 2 - 100-C Alterations

Project Engineer (Reactor): , J. W. Hedges

Project Engineer (Water Plant): J. P. Iangan

Detailed Design:

Welghted Scheduled Actual

Phystcal Performance:

Total Progress:

Construction Operation:

Project Malntenance:

$83.8 \%$

$16.2 \%$

$100 \%$

$100 \%$

Average Mappower:

Constraction Operation: 10

Project Maintenance:

2

Approx. Accumulated Nampower:

Construction Operation: 808

Project Maintenance: $\quad 140$

Directive Complet1on Date: July I, 19.57

Beneficlal Use Date:

Authorized Funds:

Apr11 1, 1957

Estimated Cost:

$\$ 765,000$

$\$ 765,000$

Acceptance testing of the pressure test facllity has been completed with exceptions. Four more rows of toggle valves have been installed. 
CG-600, Rev. No. 2 - 100-C Alterations (Con't)

Dresser couplings for the 1904 effluent line have becn shlpped, and Installation of this Iine will start early in January.

The capacity testing of the first replaced pump is continuing.

CA-615 - Mechantcal Malntenance Shop Centralizat10n - 100 Areas Project Englneer: J. H. Hoage

Welghted Scheduled Actual

Detalled Des1ga: $100 \% 100 \%$.

Physical Performance: Total Progress: Fixed Price: Constract1on Operation: Profect Malntemance:

$\begin{array}{rrr} & 86 \% & 95 \% \\ 61 \% & 100 \% & 100 \% \\ 17 \% & 55 \% & 100 \% \\ 22 \% & 66 \% & 78 \%\end{array}$

Average Mampower: Fixed Price: 0 Construction Operation: 0 Project Malntenance: 1

Approx. Aceumulated Fixed Price: 400 Construction Operation: 150 Project Malntenance: $\quad 310$

Directive Complet1on Date: Februsiry 28, 1957

Beneficlal Use Date: As components are complete

Authorized Funds:

Estimated Cost:

$\$ 92,000$ - GE \$42,000 - ABC \$50,000

$\$ 92,000$

PIant Forces continued relocation of the relding shop, blacksmith shop, and heat treating fwrmace. PIping from the oxygen and acetylene bottle manifolds is essentially complete.

CG-616, Rer. No. 2 - Installation of Ac1d Feed Equipment - 100-B, D, DR, F, and $\mathrm{H}$ Areas

Project Engineer: M. G. Patrlck

Detalled Des1ga:

Welghted Scheduled Actual

Physical Performance:

Total Progress:

Fixed Price:

Constraction operation:

Project Malntenance:

$\begin{array}{rrr} & 100 \% & 100 \% \\ & & \\ 96.4 \% & 83 \% & 79 \% \\ 3.4 \% & 87 \% & 79 \% \\ .2 \% & 20 \% & 80 \%\end{array}$

Average Manpower:

Fixed Price: 18

Constraction Operat1on: 0

Profect Maintenance:

Approx. Accumulated Mamporrer:

Fixed Price:

Construction Operation: $\quad+140$

Project Maintenance: 


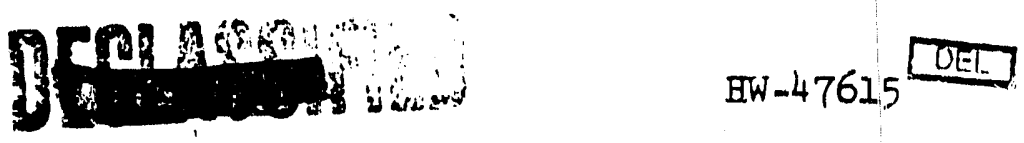

CG-S16, Rev. No. 2 - Installation of Acld Feed Equipment - 100-B, D, DR, F, and H Areas (Con't)

Directive Completion Date: April 1, 1957

Beneflcial Use Date: March I, 1957

Authorlzed Funds: $\quad \$ 443,200$

Estimated Cost: $\quad \$ 443,200$

B and C Areas: This facility is in operation.

D and DR Areas: Pipe work is progressing rapidiy in these two areas.

$F$ and $\mathrm{H}$ Areas: Work in these two areas wll progress slowly during the latter pert of December and is expected to increase very rapidly during the middle of January.

GG-618 - Replacement of Steam IIne Support Poles - 100-B, D, and F Areas Project Englneer: J. $\mathrm{H}$. Hooge

Welghted Scheduled Actual

Detalled Design: $100 \% \quad 100 \%$

Physical Performance:

Total Progress:

Construction Operation:

$\begin{array}{lll}100 \% & 100 \% & 100 \% \\ 100 \% & 100 \%\end{array}$

Average Manpower:

Construction Operation: 0

Approx. Accumalated Mamporer:

Construction Operation: 1,437

Directive Completion Date: November 15, 1956

Authorized Funds: $\$ 110,000$

Estimated Cost: $\quad \$ 110,000$

Phywical Completion Notice Issued December 12, 1956.

CG-622, Rev. No. I - Rtplacement of Discharge Chute Liners + 100-B, D, and $F$ Areas

Project Engineer: G. T. Haugland

Welghted Scheduled Actral

Physical Performance:

Total Progress:

Project Malatenance:

$100 \% \quad 75 \%$

$75 \%$

$75 \%$

Average Kanpower:

Project Malatenance: 0

Approx. Accumalated Manpower:

Project Ma1ntenance: 1,640

Directive Completion Date: July 1, 1957

Authorized Funds:

$\$ 172,000$

Estinted Cost:

$\$ 172,000$ 
CG-622, Rev. No. I - Replacement of D1scharge Chute Liners - 100-B, D, and F Areas (Con't)

Work at $100-\bar{B}$ and $D$ is couplete.

Io work at $F$ pending sultable shutdown. Present planning indicates rork Will be coupleted during the CG-558 outage:

CG-638 - Alum Act1vated Sil1ca Water Treatment Fac1l1+y - Phase II

Project gineer: M. G. Patrick

Design Englneer: H. W. Heacock

Welghted Schedured Actual

Detalled Des1gn: Not Scheduled $44.3 \%$

Physlcal Performance:

Not Started

Directive Coupletion Date: April 1, 1957

Authorlzed Funds: $\$ 275,000$

Estimated Cost: $\$ 275,000$

Revision No. I to the project proposal is being prepared by Engineering Auxillarles Operation.

CG-642, Rev. No. 1 - Cont Inuous Charge-D1scharge Equipment - C Reactor Design Engineer: H.W. Heacock

Weighted Scheduled Actual

Detalled Design:

$81 \% \quad 81.71 \%$

Physical Performance:

Not Authorized

Direct1ve Complet1on Date: Not Established

Beneficlal Use Date: Not Established

Authorized Funds: $\quad \$ 200,000$ (Interim Authorlzation)

Estimated Cost: Not Established

The mofor design effort contlnues to be directed toward design tests which will provide erldence that detall design will conform to the requirements of the design criterla for sabject project. In this regard, the major activity is in connection with:

(1) Development of rear nozzle-ball valve couponents such as seals, remote attachment methods, and hydraulic actuators;

(2) Continued testing of the discharge chute to determine optimum configuration for effective trafectory control;

(3) Seal leakage rate and pressure pulsation studies of the charging machine slider block mechanism; 
$\frac{\text { CG-642, Rev. No. } 1 \text { - Cont1muous Charge Discharge Egulpment - C Reactor }}{\frac{\left(\text { Con't }^{\prime} t\right)}{}}$

(4) Effectiveness of External Shlelding Rings for Front Face Gwo barrels.

A scope drawing which delineates the additional shlelding for the storage basin and pick-up station area was approved by the Project Representatives, and submitted to the Design Councli for thels concurrence and approval.

Some progress has been made on electrical detall design drawings which is replected in the increase in percentage completion.

CA-649 - FY 1956 - Water Tank Replacement

Project Engineer: J. A. MeCool

Weighted Scheduled Actual

Detalled Design: $100 \%$ $100 \%$

Physical Performance: Total Progress: Fixed Price: $100 \% \quad \begin{array}{ll}100 \% & 0 \% \\ 100 \% & 0 \%\end{array}$

Average Manpower: Fixed Price: 0

Directive Campletion Date: February 28, 1957*

Beaeficlal Use Date: December 13, 1956*

Authorized Funds:

Est Imated Cost:

$\$ 58,500$

Approx. Accumolated Mampower: Fixed Price: 0

The contractor's representative arrived in RIchland on December 17, 1956, to arrange for security clearances for his euployees. He notifled the Atomic Energy Commission that he expected fabricated steel to arrive plant site in about three reeks.

* The benef1clal use date of December 13, 1956, and the f1nal completion date of February 28, 195\%, w11 be resctreduled when the contractor arrives.

CA-650 - Replacement, Repalr, and/or Removal of Valve Houses - 100-B, D2 and F Areas

Project Engineer: J. A. Micool

Welghted Schedaled Actual

Deta11ed Des1gr:

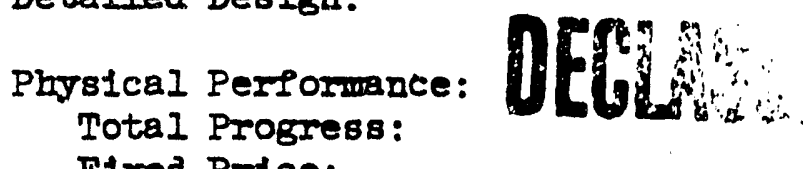

Fived Price:

$\begin{array}{lll} & 100 \% & 100 \% \\ 100 \% & 100 \% & 99 \% * \\ & 100 \% & 99 \% *\end{array}$


$\frac{\text { CA-650 - Replacement, Repair, and/or Removal of Valve Houses - 100-B, } D_{0}}{\text { and F Areas (Con't) }}$

Average Manpower:

Fixed Prico: 2

Approx. Accumulated Menpower:

Fixed Price: 625

Directive Completion Date: May 31, 1956

Authorized Funds: $\quad \$ 65,000$ - GE \$3,500 - AEC \$61,500

Estimated Cost:

$\$ 65,000$

The ADC Directive dated December 12, 1956, for Revision No. 1 to the Project Proposal, to include ten additional valve houses, wes issued.

* The actual fixed price total progress is based on the present contract for twenty-nine valve houses.

CG-651 - Continuous Charge-Discharge Equipment - "C" Pile - Demonstration Unit

Project Engineer: R。G。Knirck

Weighted Schoduled Actual.

Detalled Design:

$100 \%$

$99 \%$

Physical Performance:

Total Progress:

Project Maintenence:

$100 \% \cdot \begin{array}{ll}33 \% * & 31 \% * \\ 33 \% * & 31 \% *\end{array}$

Average Manpower:

Project Maintenance: 6

Approx。Accumulated Manpower:

Project Maintenance: 550

Directive Completion Date: September 30, 1956

Authorized Funds: $\$ 225,000$

Estimated Cost: $\quad \$ 350,000$

Project Proposal Revision No. I was approved by the General Manager, HAPO, and forwarded to the Atomic Energy Commission on December 13. This revision is requesting additional funds of $\$ 125,000$ and an extension of time to September I, 1957 .

Installation of the gamma monitoring equipment and front face auxiliary water piping is approximately 50 percent complete.

Prototype charge-discharge equipment entered a final phase of preinstallation testing with component testing, tool development, polishing of installation drawings, and preparation of a technical manual. Component testing dictated a change in the grease used to lubricate the ball valves and the use of silver-brazed joints instead of flared joints in the hydraulic and sampling water piping.

* These percentages are according to a revised schedule to be submitted with the revision to the project proposal. 


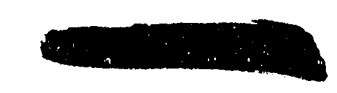

HW -47615, PI. P.

CG-654 - Advance Design - Reactor Plant

Design Engineers: $J_{0} R_{0}$ Carrell and $M_{0} H_{0}$ Russ

Detailed Design:
Physical Performance:
$\begin{array}{ll}\text { Directive Completion Date: Not Established } \\ \text { Beneficial Use Date: } & \text { Not Established } \\ \text { Authorized Funds: } & \$ 500,000 \\ \text { Estimated Cost: } & \$ 500,000 \\ \text { Status of the reactor design is: }\end{array}$

Weighted Scheduled Actual

$\begin{array}{lr}\text { Criteria } & 95 \% \\ \text { Drawings } & 100 \% \\ \text { Testing } & 51 \% \\ \text { Weighted Overall } & 83 \%\end{array}$

With the exception of component testing, the CG-654 design project work is essentially complete. On the reactor portion, two Project Representative meetings were held during the month. Seven criteria were approved which completes the scope activities of the CG-654 Project Representatives.

The drawing schedule produced under this program has been revised to include all drawings completed. It is estimated that the final count on drawings for the project will stand at 120 .

The higher cost of component testing, which has now become apparent, has required curtailment of the original test program. Critical tests, such as the crossheader diversion cannot be deloted even though costs for this single test will exceed $\$ 11,000$. Other critical development items, such as the "Dn Elevator Manipulator, must be reduced in scope. Since the re-organization, testing has progressed at an average of four per cent per month indicating that unless this program is accelerated, the CG-654 development program will continue for 12 more months.

Rough draft contributions to the CG-654 Summary Report have been prepared for the reactor and reactor building portion of the report. This will be combined with the discussions on reactor physics and fuel elements expected the first part of January and integrated into a final report (excluding the Water Plant). Additional data that has been prepared for the final report includes: (1) scheduling, procurement, and construction; (2) enticipated delivery of critical procurement items; (3) status and significance of design development testing; (4) estimate of total project construction costs; (5) estimated quantities of critical material items; and (6) estimated construciion manpower requirements by crafts. 


\section{CG-654 - Advance Deslgn - Reactor Plant}

A draft was recelved of the report prepared by Kaiser Engineers covering their architect-engineer activities on the water plant and supporting facilities. An intensive, detailed reviow was made of this draft and comments forwarded for incorporation in their firal report.

A formal cost estimate with back-up details has been received from CEO for CG-654 design and construction. The estimated total project cost is $\$ 118,000,000$. This includes the Water Plant Facilities, as estimated by Kaiser Engineers, as woll as all indirects plus 20 por cent for contingencies. The conceptual cost estimate made at the start of formal scope was $\$ 117,000,000$ 。

CG-656 - Installation of Raw Water Cross-Tie - 105-C

Project Engineer: JoC。 I。 Chatten

Weighted Schoduled Actual

Detalled Design: $100 \% \quad 100 \%$

Physical Performance: Total Progress:

Construction Operation:

$100 \%$

$55 \%$

$55 \%$

$38 \%$

Average Manpower:

Construction Operation: 0

Approx。Accumulated Manpower:

Construction Operation: 82

Directive Completion Date: February 1, 1957

Beneficial Use Date: Not Established

Authorized Funds: $\$ 27,500$

Estimated Cost: $\$ 27,500$

The installation of the cross-tie line on the near side pipe tunnel is waiting for an outage. The work scheduled for the outage on December 10, 1956, was postponed because of an unscheduled outage.

The Engineering Auxiliaries Operation has been requested to prepare Revision No. I to the project proposal requesting an extension of the completion date to May 1, 1957. 
CG-663 - Steam Auxiliaries for the 165-K Steam Generators

Project Engineer: D. M。 Diediker

$$
\frac{\text { Weighted }}{100 \%} \frac{\text { Acheduled }}{100 \%}
$$

Detailed Design:

Physical Performance:

Not Started

Directive Completion Date: August 1, 1957

Beneficial Use Date: Not Established

Authorized Funds: $\quad \$ 555,000$

Estimated Cost: $\quad \$ 555,000$

The preparation cI bid assembly is proceeding. Drawlags have been brought up to date with the latest vendor information on engineered equipment.

CG-665 - Metal Loading Facilities - 100-B, D, DR, F, and H Areas Project Engineer: J.C. Major

Weighted Scheduled Actual

Detailed Design:

$90 \% \quad 90 \%$

Physical Performance:

Total Progress:

Construct1on Operation:

Project Maintenance:

$90 \%$

$\begin{array}{ll}5 \% & 7 \% \\ 5 \% & 7 \% \\ 0 \% & 0 \%\end{array}$

Average Manpower:

Construction Operation: 0

Approx. Accumulated Manpower:

Construction Operation: 98

Directive Completion Da.te: November 1, 1957

Beneflcial Use Date: August 1, 1957

Authorlzed Funds: $\quad \$ 150,000$

Estimated Cost: $\quad \$ 150,000$

Design has been granted an extension of the completion date from December 16, 1956, to February 15, 1957, to complete electrical design. This is not expected to cause any delay in the construction schedule. The design schedule will be submitted December 29. 
CG-666 - Zone Temperature Mlonitoring - 100-B, C, D, DR, F, and H Areas Project Engineer: G. I. Swazea

\begin{tabular}{|c|c|c|c|}
\hline & Weighted & Scheduled & Acturel \\
\hline Detalled Design: & & $78 \%$ & $70 \%$ \\
\hline $\begin{array}{l}\text { Phrical Performance: } \\
\text { Total Progress: } \\
\text { Construction Operation: } \\
\text { Project Maintenance:- }\end{array}$ & $\begin{array}{l}48 \% \\
52 \%\end{array}$ & $\begin{array}{l}1 \% \\
1 \% \\
1 \%\end{array}$ & $\begin{array}{l}2 \% \\
2 \% \\
2 \%\end{array}$ \\
\hline
\end{tabular}

Average Manpower:

Construction Operation: 1 Project Maintenance:
Approx. Aceumulated Manpower: Construetion Operation: 270* Project Malntenance: 210

Directive Completion Date: January 1, 1958

Authorized Funds:

Estimated Cost:

$\$ 9010,000$

$\$ 900,000$

Construction Operation forces have started preliminary work at 105-DR. Installation of terminal strips in the waterproof duct has started. Core drflling through the rod room wall has started.

Project Maintenance forces have started planning the work for 105-DR.

The record of the quotation D-84188 for the controllers has been sent to the Manager of Purchasing Operation for transmittal to the Comisioion. The placement of the order for the controllers is scheduled for the month of January 1957.

* Estimated

CG-667 - Improved Space Ut1lization - 105-B, D, and F Buildings Project Engineer: W. P. Nicklason

Welghted Scheduled Actual

Detalled Design:

Architect-Engineer:

General Electric:

$100 \% \quad 80 \%$

$100 \% \quad 100 \%$

Physical Performance:

Total Progress:

Fixed Frice:

Construction Operation:

$48 \%$

$52 \%$

$\begin{array}{rr}26 \% & 26 \% \\ 0 \% & 0 \% \\ 50 \% & 50 \%\end{array}$




\section{HW -47615}

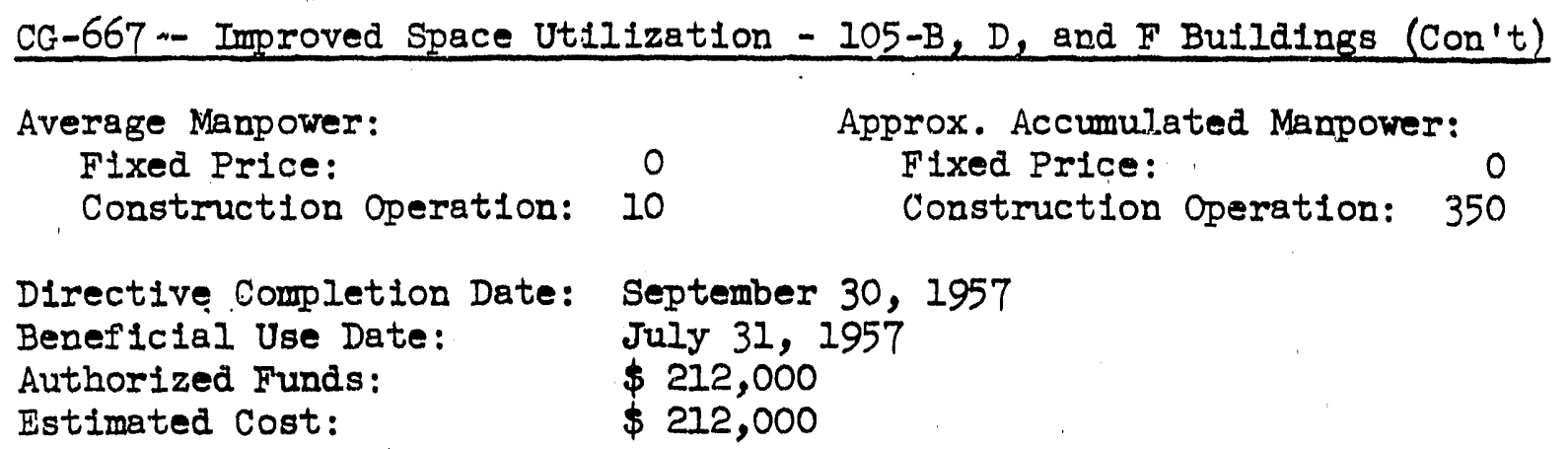

The work release addendum No. 3 , which covers the Construction Operation portion of the work, was issued this week. The total released to Construction Engineering Operation is now $\$ 59,540$. There has been a slowdown in the work because the pipefitters are being used in the 100-K Area shutdown work. The future schedules appear to be firm.

CG-669 - Water and Gas Leak Locating Equipment - Al1 100 Areas Project Englneer: C. I. Owen

Weighted Scheduled Actual

Detalied Desțgn: $100 \%$ $98 \%$

Physlcal Performance: Total Progress: Pro.ject Maintenance: $\begin{array}{lll}100 \% & 100 \% & 58 \% \\ 100 \% & 58 \%\end{array}$

Average Mampower: Pro.ject Maintenance: 0

Approx. Accumulated Mamower: Project Maintenance: 387

Directive Complet1on Date: October 3I, 1956

Beneficlal Use Date:

Authorfzed Funds:

Estimated Cost:

*

$\$ 112,000$

$\$ 190,000$

* Benericial Use Dates

$\begin{array}{lcc}\text { Area } & \text { Water } & \text { Gas } \\ \text { B } & 4-12-56 & 10-15-56 \\ \text { C } & -- & -- \\ \text { D } & 4-12-56 & 10-15-56 \\ \text { DR } & 4-12-56 & -- \\ \text { F } & 4-12-56 & -- \\ \text { H } & 8-14-56 & 8-14-56 \\ \text { KE } & -- & -- \\ \text { KW } & -- & -\end{array}$

100-B Area was completed with minor exceptions on December $14_{2} 1956$.

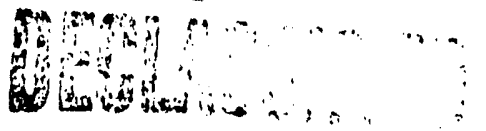


CG-669 - Water and Gas Ieak Locat1ng Equipment - AII 100 Areas (Con't)

The revision to the project proposal was transmitted for approval within the Irradiation Processing Department on December 18. Revision No. 1 to the project proposa]. now requests an extension of time to september 1 , 1957, and additional fiuds of $\$ 78,000$. This brings the total authorized funds requested to $\$ 190,000$.

CG-674 - Water Plant Component Test Loop - Bullaing 1706-KE

Project Engineer: C.. E. Love

\begin{tabular}{|c|c|c|c|c|}
\hline & . & We1ghted & Scheduled & Actual \\
\hline Detalled Deslgn: & ' & & $100 \%$ & $100 \%$ \\
\hline
\end{tabular}

Directive Completion Date: December 31, 1957

Authorized Funds: $\$ 125,500$

Estimated Cost: $\quad \$ 125,500$ :

The design of the assembly is complete, and a requisition has been submitted for procurement. B1ds were due December 26, 1956.

CG-678 - Iaboratory Factlities for the Special Irradiation Studies Project Englneer: D. M. Diediker

Welghted Scheduled Actual

Detalied Design: $92 \% * \quad 50 \% *$

Physical Performance:

Not Started

Directive Completion Date: October I, 1957

Authorlzed Funds: $\$ 45,000$

Estimated Cost: $\quad \$ 45,000$

Deta1l deslgn by W. C. N1ckum \& Sons is proceeding. Preliminary drawings ard speciflcations have been revlewed, and comments returned to ArchltectEngineer.

* Design re-scheduled November 29, 1956. 
CG-684 - Adequate Fresh Air Systems - 105-B, D; DR, F, and H Areas Pro.ject Engineer: H. A. Zwelfel
Welghted Scheduled Actuel
Detailed Design:
$100 \%$
$100 \%$
Physical Performance:
Total Progress:
Pro.ject Malntenance:

$\begin{array}{lll}100 \% & 26 \% & 18.5 \% \\ 26 \% & 18.5 \%\end{array}$
Average Manpower:
Project Malntenance: 3
Approx. Accumulated Manpower:
$\begin{array}{ll} & \\ \text { rective Completion Date: June } 2,1 \\ \text { thorlzed Funds: } & \$ 88,500 \\ \text { timated Cost: } & \$ 115,000\end{array}$
Work on the "C". Elevator in the 105-B Area has been delayed due to high gaseous radiation. Completion of the piping on the "C". Elevator is
planned for the month end. Installation of the Alr Separator Cooler in the Accumulator Room has continued.
Delivery of the air recelvers is promlsed for the end of the month. Their Installation at 105-B is scheduled for the first reek in January.
CG-689 - Slug Saw and Etching Equipment - 105-C Butlding
Equipment Development Engineer: P. B. McCarthy

\section{We1ghted Scheduled Actual}
Detailed Design:
Not Started
Physical Performance:
Not Authorized
Directive Completion Date:
Beneficlal Use Date:
Not Establ1shed
Authorized Funds:
$\$ 47,750$ (Design Only)
Estimated Cost:
$\$ 100,000$
The scoplng and design schedules are being planned.
* Anticlpated detalled des18n completion May, 1957. 
CA-690 - Foof Repairs - 190-D, F, and 186-D Builalngs

Pro.ject Englneer: J, H. Hoage

Welghted Scheduled Actual

Detalled Des1gn: $100 \% \quad 100 \%$

Physical Performance:

Total Progress:

Fixed Price:

$100 \% \quad \begin{array}{ll}100 \% * & 100 \% * \\ 100 \% * & 100 \% *\end{array}$

Average Manpower:

Fixed Price: 3

Approx. Accumulated Mampower:

Flxed Price: 262

Direct1re Complet1on Date: January 15, 1957

Authorlzed Funds: $\quad \$ 28,000-G E \$ 4,500-A E C \$ 23,500$

Estimated Cost: $\quad \$ 28,000$

Contractor began repalrs to 105-C Roof on December 14, 1956. The contractor was requested to locate and repair a leak in the 10 foot level roof near Office No. 2. The leak developed after the 105-C work was scoped.

* The contractor, C. C. Hill, completed the inftial contract work on November 30, three days ahead of schedule. He was notified November 20 by the Comnission to proceed whth an additional 2,800 square feet of roof repair on the 105-C Building.

CG-694 - Auxiliary 01I Pumps - 100-C

Project ingineer: J. P. Langan

Welghted Scheduled Actual

Physical Performance:

Not Started

Direct1ve Completion Date: December 15, 1957

Benef1clal Use Date: November 15, 1957

Authorized Funds: $\$ 80,000$

Estimated Cost: $\quad \$ 80,000$

A possible revision to the project proposal, to delete some of the facillties requested, is being investigated.

CA-702 - Relocate Dormitories - 100-H Area

Project Enjineer: W. P. N1cklason

Welghted Scheduled Actual

Detalled Deslgn:

Construction Engineerlag Operation:

$100 \% \quad 100 \%$

Physical Performance:

Not Started 
CA-702 - Relocate Dommitorles - 100-R Area (Con't)

Direct1ve Completion Date: October 31, 1957

Beneflcial Use Date: April 30, 1957

Authorized Funds:

Estimated Cost:

$\$ 120,000$ - GE $\$ 20,000-\operatorname{AEC} \$ 100,000$

Design forces did not meet the scheduled design date of December 11 and indicate design was completẹ December 29 . The bid package is being prepared for the Commission." Travel routes are being studied.

$\frac{\text { AEC-160, Rev. No. } 2 \text { - Recirculating Gas Loop }}{\text { Project Engineer: M. G. Patrick }}$

Welghted Schedaled Actual.

Detalled Des1ga:

$80 \%$

$55 \%$

Physical Performance:

Not Started

Directive Complet1on Date: Not Established

Beneflcial Tise Date: Not Established

Authorized Funds:

$\$ 80,000 *$ (Interim Authorization)

Estimated Cost: Not Establishod

A new design schedulle has been prepared. There 18 no change in the previously scheduled completion date, only a change in the slope of the
curve.

- Revision No. 2 to the Project Proposal AEC-160 was written by the Comission Norember 12, 1956. The AEC Direct1ve No. AEC-87, Modification No. 2, was 1ssued December 12, 1956. The FHM-3360 was 1ssued December 19. 1956. 
F. SIgnificant Reports Issued

\section{Routine Reports}

Monthly Management Report, by J.S. McMahon, for December, 1956.

Seminonthly: Project Status Report, by G. R. Bauer, dated December 14, 1956.

Semimonthly Project Status Report, by G. R. Bauer, dated December 28, 1956.

Monthly Record Report, by J. S. McMahon, for December, 1956.

Weekly Activity Report - Profect Proposals, dated December 7, 1956, December 14, 1956, and December 28, 1956; by Proposals and Appropriations Operation.

Pro.ject Proposal Status Report, by F. A. Snyder, dated December I, 1956.

General Manager's Monthly Project Report, by G. R. Bauer, dated December . 1, 1956.

2. Non-Routine Reports

Number

Subject

Author

No Number, "Tube Replacement Report", November 17, 1956.

No Number, "Investigation of Current Status of Electrical Distribution System - 105-B,

H. R. Hughes D, and F", November 2I, 1956.

HW-4593I, "Summary Reports of In-P1le Internal and External Conversion Ratio Exposure

A. G. Dunbar Results Relative to Production Test PT-105-615-A-63-MP", November 7, 1956.

HW-47067, "Procurement of Heavy Aggregates for Project $\mathrm{CG}-654$ ", November 30, 1956.

B. E. Smith

and Extermal Conversion Ratio Exposure
Results Relative to Production Test -
PT-105-615-A-63-MP", November 7, 1956.
BW-47088, "The Design and Application of a Heat Transfer Analogue for Radially Symetrical Problems", December 4, 1956.
HW-47121, "Project CG-558 Representatives Meeting Number 52", December 4, 1956.
H. W. Heacock
M. W. Cook "Project Representatives Meeting Number
HW-47195, "Project Representative
10", December 10, 1956.
J. R. Carrell

H. S. Davis 


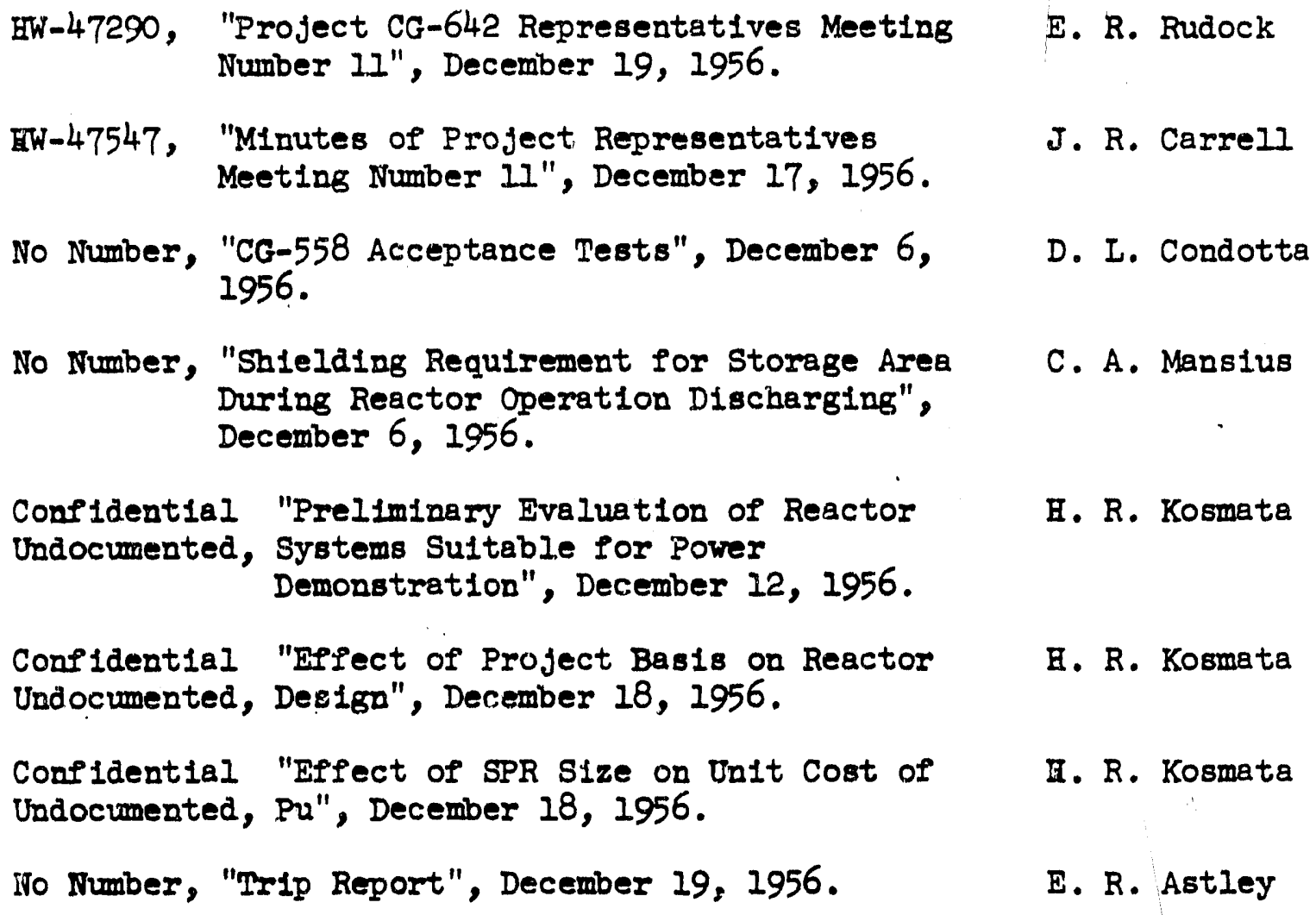

III. ORGANIZATION AND PERSOMNEL

\section{A. Organization}

Marvin P. Black transferred into Equipment Development Operation from Finished Product Operation on December 17, 1956, as an Engineering Assistant 12.

J. E. Mahaffey, a Technical Graduate - Rotational, transferred from Equipment Development on December 26, 1956, to Research and Engineering.

J. H. M. Miller, Supervisor Project Engineering "C", Project Engineering Operation, transferred to KE and KW Reactor: Operaticin on December 21, 1956.

Elaine Burke transferred to Process Design Operation as Secretary "B" from Bngineering Auxillaries Operation on December 24, 1.956.

Caroline W. Gerneglia, a Secretary " $B$ " in Process Design, reslgned on December 7, 1956, to return to Seattle where her husband 1s working.

Harrlet $F$. Bartle transferred from Relations and Utilities Operation to Plant and Industrial Engineering Operation on Deceraber 10, 1956, as a Steno-Typist.

Belva E. McGrew, a Steuo-Typist, transferred from Englneering Auxiliaries Operation to Principal Englneers on December 10, 1956.

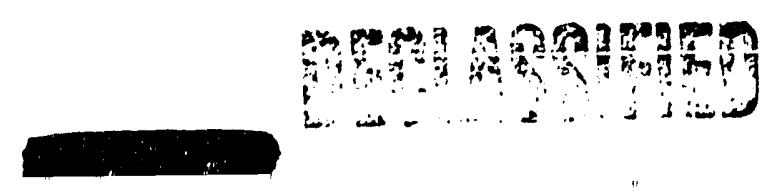


The following personnel transferred into Project Malntenance Operation on December 10, 1956:

0. L. BaIlard

J. W. Maxwell

J. I. FIscher

The following personal transferred from Profect Maintenance Operation on December 10, 1956:
D. M. Decker
D. I. Graham
K. D. Staley

W. C. Royce was reclassifled from Senior Project Engineer to Sipervisor, Project Engineering "C", on December 21, 1956.

S. O. Arneson, an Encineer II, transferred from Materials Development to Mechanlcal Development "B", on December I, 1956.

B. Force Summary

\begin{tabular}{|c|c|c|c|c|c|c|}
\hline Beglnx & $\operatorname{lng}$ or & Month & $\underline{E n}$ & of Mor & & Net \\
\hline Exempt & Other & Total & Exempt & Othex & Total & Change \\
\hline 174 & 123 & 297 & 173 & 125 & 298 & +1 \\
\hline & & 18 & & & 18 & 0 \\
\hline
\end{tabular}

Technical Graduates

Following are changes during the month:

F.E.0. Technical Graduates

Payroll Add1tions.

Payroll Removals

Transferred Into Operation

Transferred Irom Operation

0

$\frac{1}{6}$

6

C. Safety Experience

There were elght medical treatment injurles sustained during the month. All components of Facilities Engineering Operation held safety meetings.

Otte employee, J. W. Hedges of Project Engineering (B), was Involved in a near-serlous accident on the front face elevator, 105-B, during acceptance test procedures. A high pressure water hose ruptured and he was struck on the forearm by the high pressure jet of water. No lost time was involved.

D. Security Experience

There were an securfty violations during the month. All components of Facilities Engineering Operation held security meetings. 
E. Radiation Experience

No exposure in excess of permissiole radiation limits wa reported.

F. Personnel Activities

1. Visitatious

J. P. Cooke attended an AIChE meeting in Boston and presented a Chalrman's Report for the Professional legislation Commlttee. In Waterford, New York, he visited the G. E. Silicone plant to discuss latest test development and product applications with Messis. Paul Goodwin and Joseph Deasy. In Schenectady, he visited the General Englneering Laboratory to talk with D. J. Santiler on high-vacuum techniques, leak detector servicing, and related problems.

M. R. Wood was on a trip to Jordan Electronics, Los Angeier, December 9-18. The primary purpose of the trip was in support of Project CA-512-R, Gamma Spectrometer (Fuel Rupture Detection) procurement. The prototype will be tested and approval given to start fabrication if tests are satisfactory, side trips will be made to companies in the Ios Angeles and San Francisco areas to investigate neutron monitoring devices and circuitry.

E. R. Astley visited KAPI on December 13 and 14 , to discuss methods of calculating high energy group constants necessary for the physics analysis of the Plutonium Recycle Frogram reactors. He also attencied a meeting of the American Nuclear Society in Washington, D. C. on December 9 through 11 .

Dr. W. J. Love of Denver, Colorado, visited HAPO from December 11 to 22, 1956, to provide consulting services regarding the design of the CG -558 process water systems.

H. H. Hubble attended an AIChE meeting in Boston, December 9 through December 12. This trip was combined with a business visit to Dr. Paynter of M.I.T. in connection with his consulting contract involving Project CG-558 work.

\section{Training}

Six members of Plant and Industrial Engineering attended the training session "Practical Business Writing I".

Nine Engineers of Plant and Industrlal Englneering attended classes on "Work Simplification".

Sixty-nine persons attended "Value Analysis Orientation" Lectures held in each 3.00 rrea during Decemiver.

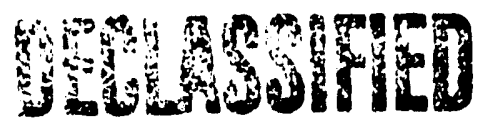




\section{HW-47615 DEL}

Twelve classes of two hours each were held to acquaint maintenance craftsmen with the operation of Ramset powder-actuated tools. A total of 174 men attended these sessions.

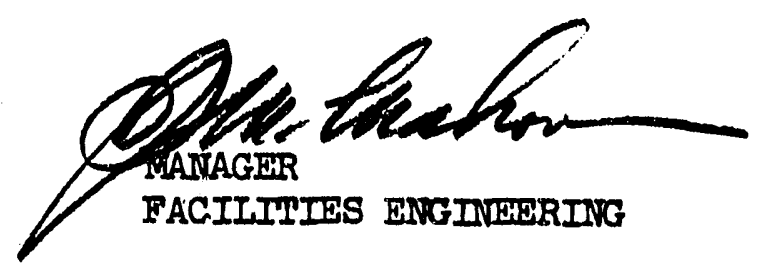


REPORT OF INVENTIONS

FACIIITIES EIVG INEERING OPERATION

IRRADTATION PROEESSING DEPARTMENT

DECEMEER, 1950

All persons engaged in work that might reasonably be expected to result in inventions or discoveries advise that, to the best of their knowledge and belief, no inventions or discoveries were made in the course of their work during the period covered by this report, except as listed below. Such persons further advise that, for the period therein covered by this report, notebook records, if any, kept in the course of their work have been examined for possible inventions or discoveries.

\section{Inventor}

Evan W. Baker

E. R. Rudock
Title

Audible Railroad Crossing Warning

Flange Seal-(providing a variable compression while maintaining $a$ seal)

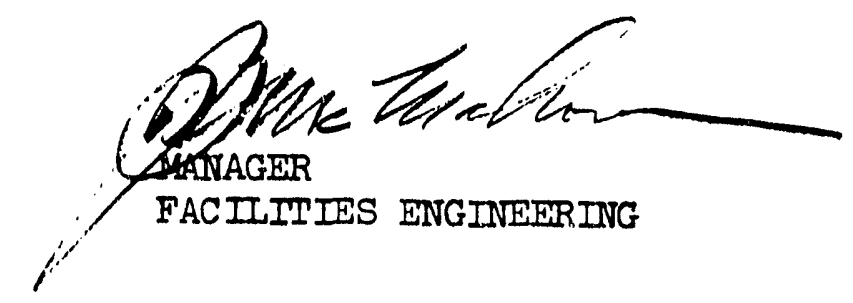




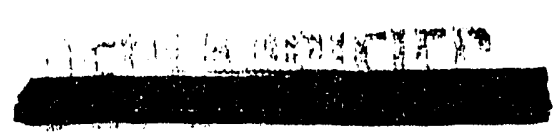

EMPLOYEE RMLATIONS OPERATION

December 1956

\section{PIRSONNEI DEVEIOPMENT \& COMMINICATION OPERATION}

\section{Geners]}

There was no change in component responsibilities, organization, or force during December. No lost time or medical treatment injuries occurred.

Number of Personnel

Nor. 30. 1956 Dec. 31.1956

Exempt

Nonexempt

Total

Communication Activities

Five Management News Bulletins were issued on toples of broad and timely interest to IPD Management. Upon request of several Operations Managers, a monthly periodical "Supervisory Management" has been ordered for distribution.

GE NEWS coverage, maintained at an appropriate level, included a feature story on a typical IPD shift worker, material concerning the Nonexempt Personnel Development Program, a half-page feature on new mail delivery equipment, and a feature on a substantial suggestion award. The following tabulation indicates the extent to which the GE NEWS is used as a communication media by the Department.

\section{IDD GE NIEWS COVERAGE}

This Month

Inst Nonth

Year to Date

Bhotos

No, Published

27

Column Inches

248

11

16

136

94

864

Text - Column Inches

40

157

Total - Column Inches 259

276

1103

\section{Personne] Derelorment Activities}

Essentially all material was received for the PBM-I course and the necessary planning and scheduling accomplished. Four groups totaling 66 members of management will meet for the pre-course orientation session in the first week of January.

Three Supervisor's Training Classes on the Intent and use of the Nonerempt Personnel Development Program were conducted by the Specielist.

Discussion meetings were beld with about $50 \%$ of level 3 managers on the subject of this operation's present and planned manpower development objectives. The organizational and staffing problems of these customer operations obviously 
affect the nature and direction of development programs to be undertaken by Personnel Development.

All applicable data recelved concerning the Atomic Energy Training Activities of IFD personnel during 1956 was summerized in tabular form and submitted to R\&U. Likewise, a report of proposed IPD In-Plant Training courses for the quarter was complied and submitted.

In connection with appraisal of exempt personnel in progress a listing of selfdevelopment methods was compiled and distributed to IPD Management. The first Nonexempt Personnel Development Program appraisal forms were distributed to supervisors having employees with CSD anniversaries in January.

Two Advices on the Nonexempt Personnel Development Program were revised and submitted for issuance within the Department. Work continued on an exempt roll manpower inventory, including a literature survey on the application of punch card filing systems, and investigation of several systems presently in use.

Copies of the November status of the Personnel Development Program for Nuclear Engineering were distributed to all level 3 managers. Present status of assignments to the Program in IPD is shown in the following tabulation:

\section{signment}

Research \& Engineering

Facilities Engineering

B-C Reactor

D-DR Reactor

F Reactor

H Reactor

K Reactor

Totals

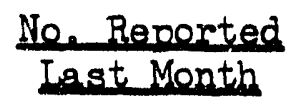

17

19

2

3

1

3

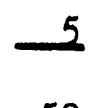

50

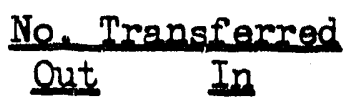

5

5

2
No. Present End of Month 22

14

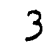

$I$

3

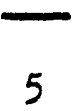

3 (n)
Final arrrangements were made for craft training session on Ram-Set PowderActuated tools and by month-end the program had been completed. A total of 450 craftsmen and supervisors have been trained since inception of this program one year ago.

Scheduling of several exempt personnel training courses to be held in the first guarter of 1957 neared completion.

Nivere was a noticeable increase in the rate of progress toward completion of reeveluations to be performed in the Supervisory Selection Program. The status of the program is shown in the following table: 
This Month

New evaluations completed

Evaluation under way but incomplete 2

Re-evaluations performed

Re-evaluations under way but incomplete

Re-evaluations outstanding

Nominations outstanding Appointments from the Program Total candidates in Program
Iast Month

0

4

68

61

16

0

153

16

0

152
Sept I to Date

4

21 


\section{HEALTH \& SAFETY}

Personnel

Employees: Exempt 4: Non-exempt I.

Accident Statistics

December 9-1-56 to Date

Disabling Injuries Freouency Severity

Medical Treatment Injuries Frequency Estimated Hours of Exposure since last Disabling Injury (10-17-56) 989,536

Fires

Loss

Security Violations
0

0

0

85

2.16

None

0

2
1

0.64

20

363

2.32

General

In excess of 5,500 Diabetes detection test strips were ordered by employees of I.P.D.

The 1957 Program Council held its initial meeting with objectives, goals and purposes discussed. Scheduled monthly meetings for 1957 were forecast.

The Department Rescue Crew Program has been completed with training activities planned throughout 1957. The Civil Defense Program is being reviewed with the AEC insofar as the current requirements of personnel remaining in Power House Areas are concermed.

Ninety Work Restriction Cases have been reviewed since 9-1-56. Each restriction has been reviewed with immediate supervision. Many restrictions have been eliminated.

The attitude of supervision and employees toward Safety is very satisfactory.

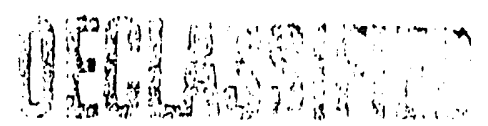




\section{PERSONNEL PRACTIOES}

\section{GENERAL}

There were no changes in the organization nor assigned responsibilities of the Personnel Practices Operation during December. A talk, "The Challenge of Atomic Energy" was presented by the Manager-Personnel Practices to the student chapter of the A.I.Ch.E. and the A.C.S. at the University of Colorado on December 12. No injuries nor security violations were experienced. A total of 32 overtime hours were worked in Duplicating, as contrasted with none during November.

\section{TECHNICAI PERSONNEL PLACEMENT}

1. Ph.D. Activity

Information on several candidates has been reviewed; however, there were no interviews this month.

2. BS-MS Recruitment (Experienced)

December* November

Active cases being centralized by IPD

Candidates of interest to IPD, but centralized by others

Offer letters Processed

IPD Offers Accepted

IPD Offers Rejected

Offers, candidates considering

59

$$
\begin{aligned}
& \text { *Thru December } 21 \text { only } \\
& * \text { HOne of these offers is a joint offer. }
\end{aligned}
$$

3. BS-MS Recruitment (College)

Assistance in the campus recruitment of engineering and technical personnel was provided during the month by the Specialist - Technical Personnel Placement, as a member of the G. F. Region 5 recruiting team at the University of Missouri and Missour1 School of Mines, December 4-7 inclusive.

\section{Transfer Cases}

December November

Active Cases within IPD

IPD interest from other HAPO Departments

Transfers, other HAPO Depts. to IPD

Transfers, from IPD to other HAPO Depts.

IPD transfers to other GE Sites

$\begin{array}{rr}20 & 16 \\ 8 & 4 \\ 2 & 0 \\ 1 & 0 \\ 2 & 1\end{array}$

The additional interest in IPD from other HAPO Departments stems from technical personnel in CPD whose activities are being somewhat curtailed. 
Military Reactivates

Active cases in process

Offers Extended

Offers Accepted

Offers Rejected

6. Summer Placement Program

Active cases in process

Offers Extended

Offers Accepted

Offers to visit
December November

5

$1 \quad 0$

$\begin{array}{ll}0 & 1 \\ 1 & 0\end{array}$

December $\quad$ November

$\begin{array}{ll}5 & 0 \\ 1 & 0 \\ 1 & 0 \\ 4 & 0\end{array}$

\section{EMPLOYMENT}

1. Employes Service Recognition Plan

Both November and December awards were made this month, IBM information having been brought up to date. A total of 48 service recognition pins were distributed as follows:

No. of Awards-November

No. of Awards-December

Yrs, of Service

12

TOTAL $\frac{8}{20}$
16

$\frac{12}{28}$

2. Attendance Recognition Plan

No. of Awards

7

8
4
4
8
6
TOTAL $\quad 37$

Years Perfect Attendance

$$
\begin{aligned}
& 1 \\
& 2 \\
& 3 \\
& 4 \\
& 5 \\
& 6
\end{aligned}
$$

3. Requests for transfer

On hand 11-30-56

New Requests received

Transfers completed

Requests cancelled

Int erviews conducted

Requests on hand 12/25/56

Non-Unit

Employees

2

$8 \%$

1

1

$\frac{0}{8}$
Unit

$\frac{\text { Employees }}{10} \quad \frac{\text { Total }}{12}$

$23 * *$

1

0

$\frac{1}{32}$
31

2

1

$\frac{1}{40}$

*3 IPD non-Unit requests were added during December on transfer of request records in possession of Relations \& Utilities Employment

- -19 IPD non-Unit requests were added also upon receipt of transferred records from Relations \& Utilities Employment. 


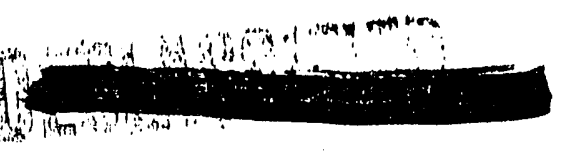

4. Personnel Changes

Additions to Payroll:

New hires. 2

Re-engaged 0

Reactivates 4

Transfors 10

Rehires

Total Additions 17

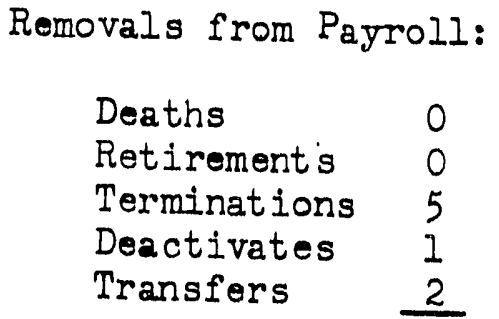

Total Removals 8

5. Requisitions

No. of openings as of $12 / 1 / 56$

Additional openings thru $12 / 25 / 56$

Openings cancelled

No. of openings filled

No. of openings as of $12 / 25 / 56$

*Comittments made on 8 of thest openings. 13 openings are on a hold
status. EMPLOYEE BENEFITS AND SERVICES

\section{Military Service}

Interviews:

Returned from Military

Letters Requesting Deferment or Reclass-

ification

Deferment in S.S.S. Draft

Reclassification of Standby Reserve

Availability Status

Deferments allowed for one year

Deferments denied for one year

2. Employee Purchases

Special purchases handled by this office

Complaints by employees investigated \& resolved

Letters written to obtain special G.E. goods

TOTAI
39

9

2

15

$31 *$

\section{December November}

TOTAI

$\begin{array}{ll}3 & 4 \\ 2 & 4 \\ 1 & 0\end{array}$

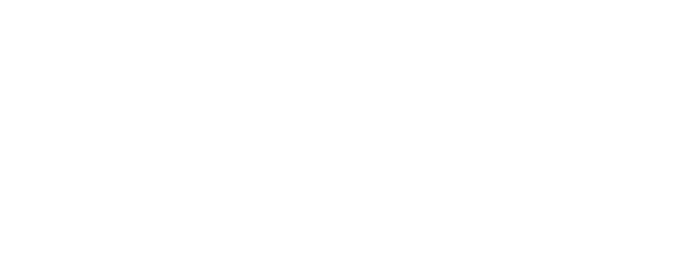

\section{Retiroment Program}

1

0

0

0
4
4

0

3

4. Emoloyee Loans

Educational Loans initiated Educational Loans completed 
An information sheet, "How to Make Out Insurancs Claims", four pages of questions and answers, and a cover letter comprioed a package sent to all employees early in December.

\section{MAIL AND DUPLICATING}

1. Mail

Heavily populated buildings were equipped with mail carts, and mail personnel began use of portable mail distributors designed to reduce injury hazards and increase efficiency. The equipment was publicized in the December 29 issue of the G. E. News.

Mail deliveries proceeded without delay or incident in spite of several days on which icy roads and reduced visibility due to ground fog were experienced.

Four additional mail stops were created in order to provide service to a T. C. (Temporary Construction) building in 100-D Area.

\section{MAII STATISTICS December November}

Pieces of registered delivery mail

Pieces of Postal Mail

Pieces of regular mail

Number of addressograph orders handled

Number of addressograph Impressions

$\begin{array}{rr}2121 & 2742 \\ 294 & 468 \\ 578,401 & 574,321 \\ 14 & 17 \\ 5754 & 7858\end{array}$

2. Duplicating

Deadlines for priority duplicating service were met without exception. One new duplicating facility was opened in 100-D Area on December 5. Favorable comment is being received from that area on the added speed and convenience in obtaining duplicating service.

\section{DUPLICATING STATISTICS December November}

Orders received

Orders completed

$879 \quad 1095$

Orders on hand

$840 \quad 1072$

Xerographic Masters made

$120 \quad 264$

$521 \quad 767$

Total Masters handled

$3184 \quad 4400$

Number of copies duplicated

$195,905 \quad 245,807$


SALARY AND WAGE ADMINISTRATION

\section{Salary Administration}

The position audit program continued through the month, directed to the firstIine supervisory positions in the Reactor Operations, and in positions of comparable level in Facilities Engineering and Research and Engineering Operations.

Further study was directed to the problem of appropriate pay differential between first-line supervisory positions and the people supervised. The upward pressure of increased non-exempt pay rates have forced the practice of using starting rates for first-line supervisory positions which are in zone two or zone three, rather than the more appropriate Position Rate.

\section{Changes in Salary of Personnel}

$\begin{array}{ll}\text { Promotional Increases } & 4 \\ \text { Salary Review Increases } & 17 \\ \text { Interim Merit Increases } & \\ \text { Salary Adjustments } & \\ & \\ \text { Total } & \end{array}$

\section{Wage Administration}

Recommendations were drafted to establish a more equitable system of classifications for secretaries. The proposed grades for these classifications are supported by the recent Northwest wage survey. The latest Davis-Bacon minimum rate schedule was revlewed, and comparisons made to the craft rates paid by General Electric at H.A.P.O. Also, a study of rate comparisons for H.A.P.O. Reactor operating jobs, compared to the rates in other locations was completed.

Changes in Salary of Personnel

$\begin{array}{ll}\begin{array}{l}\text { Automatic Increases } \\ \text { Reclassifications } \\ \text { Merit Increases }\end{array} & \frac{156}{43} \\ & =199 \\ \text { Total } & 199\end{array}$

\section{Salary and Wage Records}

Salary and Wage records have been brought up to date following reorganization and are now being maintained on a current basis. Records now maintained are being expanded to reflect the most desired and irequently used type of information. This has been done, except for two or three specific files which we are in the process of establishing. One of these, in particular, consists of a set of cards on non-exempt employees which will be filed by job title, containing the essential information relating to the employee's job pay rate and progression. This file will actually be a cross-file, since cards bearing similiar information are filed alphabetically. 
The exempt organization directory has been completely revised and is now in the process of being placed on duplimats for reproduction. We expect issuance of the revised directory shortly after January 1, 1957. The directory will reflect the organization as of January 1, 1957.

Copies of the new salary structure, which became effective December I, have been received and distributed to management personnel as required. 
The Bureau of Labor Statistics' cost-of-living index of November 15 reached a new high of 117.8 as compared on September 15. It is expected that the December 15 index will remain at approximately the 117.8 level and that in accordance with our cost-of-living formula non-exempt employees will be entitled to a $1.18 \%$ increase in base rate around February $i$.

Five of the eleven grievances processed at Step II during the month involved work assignments. The HAMTC's charge is that an increasing amount of work, historically performed by Maintenance craftsmen, is now being assigned to Minor Construction forces. The situation is created by: (1) Davis-Bacon aspects of the work, and (2) manpower ceilings. The situation is considered serious and steps are being taken to determine the degree to which the charges are valid, and the extent to which our current work assignments deviate from past practices.

The Council has agreed to withdraw the unfair labor charge filed against the Company in October and submit a joint petition to the National Labor Relations Board for a decision as to whether certain work, being performed in Burildings 1706-KE and KER, 100-K Area, is production work subject to inclusion in the original certification of the HAMTC. No further action has been taken by the parties since the petition was submitted to the Board on November 19. In the near future, the petitioners will submit to the Board a statement of facts upon which they agree and each petitioner will also submit a statement of its contentions.

Union dues check-off figures for December show that $63.2 \%$ of the bargaining unit employees in IPD are signed up for check-off compared to a plant average of 54.4\%. The Chemical Processing Department has $60.4 \%$. One factor causing this camparatively high percantage of union membership is the large number of craftsmen in these Departments. Such emplojees bistorically have strongly supported union activities.

\section{IPD Grievance Statistics 17-26-56 through 12-25-56}

A total of 14 grievances were received and four Step II grievance meetings were held. Following is a breakdown of the status of these grievances:

\begin{tabular}{lcc} 
& Unit & Non-Unit \\
\cline { 2 - 2 } Received this month & 14 & 0 \\
Received this Jear & 213 & 1 \\
Step I & & \\
Answer unsatisfactory & 11 & 0 \\
Answer satisfactory & 3 & 0 \\
*Pending time limit & 14 & 0 \\
Settled this month & 6 & 0
\end{tabular}




\section{Step II}

Discussed this month Pending time Iimit

Settled this month

$\begin{array}{cc}17 & 0 \\ 8 & 0 \\ 5 & 0 \\ 2 & 0 \\ 17 & 0\end{array}$

* Step I grievances which Council indicated desire to discuss at Step II, out not scheduled or have been discussed but not answered, are considered settled at Step I after three months.

* Step II grievances which the Council has formally indicated their intention to arbitrate are shown settled at Step II after three months, if no further action is taken.

\section{Subject of December Grievances}

Unit

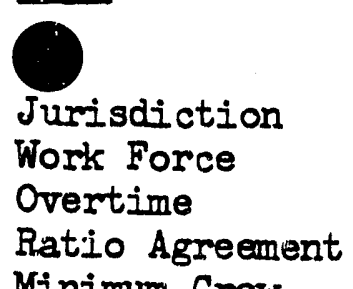

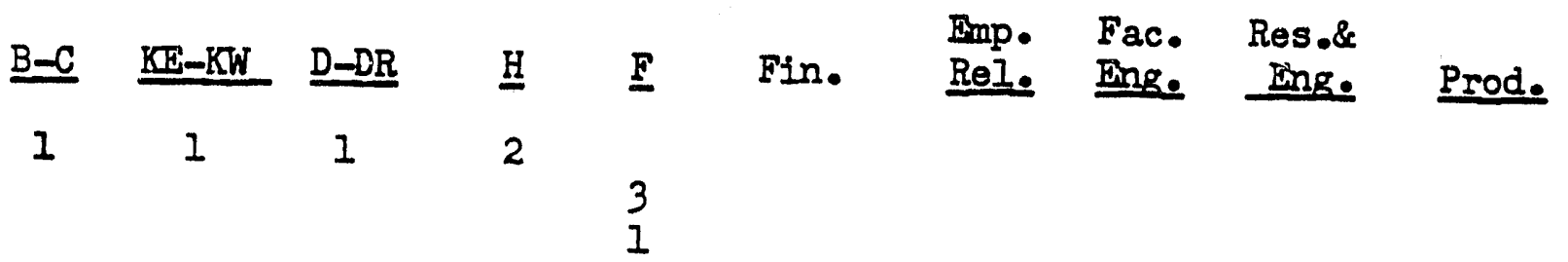

Minimum Crew

1

1

Detail Procedure

Insurance Plan

Transfer

TOTAI

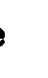
1

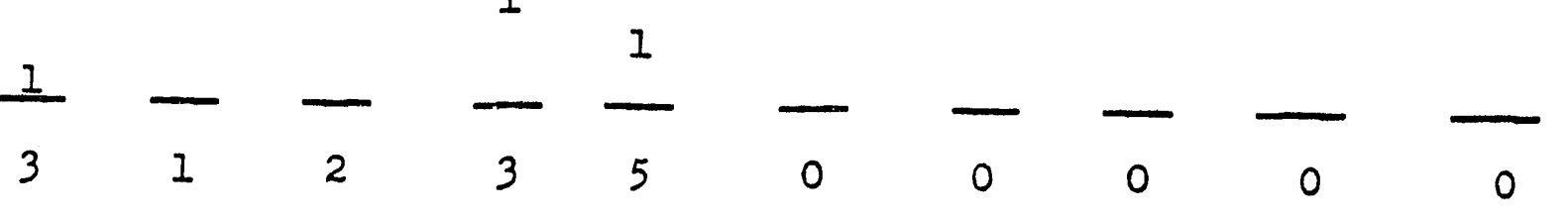

Non Unit

0

00

00

0

0

0

0

0 


\section{FIRE PROTECTION}

Organization and Personnel

Employees - Beginning of Month New Hires (General Clerk A)

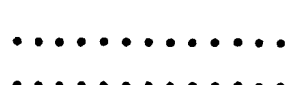

De-act1vated Personnel Returned to Duty.........

Eimployees - End of Month

$\begin{array}{cc}\text { Exempt } & \text { Non-Exempt } \\ 11 & \frac{40}{1} \\ 11 & 42\end{array}$

Fire Responses

None

\section{Drilis Held During December}

Outside Drills

Inside Drills

Feet of Hose Used on Drills

Feet of Ladders Used on Drills

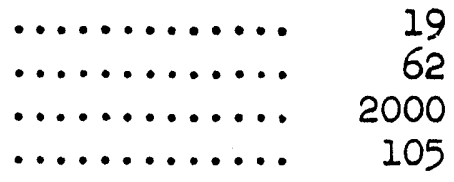

Meetings

Types of Meetings

Round Table

Security

Safety
No. of Meetings

4

4
8
No. Attending

44

42

84

Fire Extinguisher Activities

$\begin{array}{llr}\text { Inspected } & \ldots \ldots \ldots & 438 \\ \text { Installed } & \ldots \ldots \ldots & 8 \\ \text { Seals Broken } & \ldots \ldots \ldots & 13 \\ \text { Serviced } & \ldots \ldots \ldots & 158 \\ \text { Weighed } & \ldots \ldots \ldots & 213\end{array}$

Fand Iines Inspected ........ 38

Hose Boxes Inspected ........ 16

Gas Masks Serviced $\ldots \ldots \ldots . .2$

Gas Masks Inspected ........ 15

Sprinkler Systems

Generel

Two new 750 gallon per minute Ward Ia France pumpers vere recelved on December 10, 1956 to replace two 1942 war model pumpers. Trucks w1ll be assigned to IPD and CPD. Testing and checking was completed on December 17 and trucks will be placed in service in Januery.

A class on artificial resplration vas conducted by Firo Protection personnel for 14 members of the 184-F Butlding.

A I1re extingulsher demonstration vas held for nine members of the 105-C Bullding in the 100-B Area.

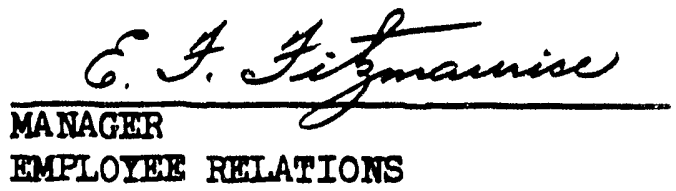


FINANCIAL OPERATION

HW- 47615

MONTHLY RECORD REPORT

DECEMBER, 1956

\section{Administrative Planning}

A total of 13 OPG's and Advices were released for publication and distribution during the month. In addition, 12 previously published Advices were revised and issued, incorporating improved procedures developed subsequent to initial issue.

A total of 14 scheduled OPG's and 28 scheduled Advices are still under development, awalting inftial publication under the reorganization. IPD Managers were so advised. All HAPO departments and operations have been requested to provide two coples of each of thelr OPG's or Advices. One is kept. on flle for departmental reference, the other is being directed to the Level III Manager principeliy interested in order to permit comparison and further development.

The deadine of December 21 for all rough draft articles to be Included in the IPD portion of the HAPO Annual Report was not met due to the press of other priorlty work. Current estimates indicate completion of articles by January 11 , 1957.

\section{General Accounting}

General Accounting personnel as of December 31, 1956, consists of 7 exempt and 23 nonexempt personnel. J. A. Leger was transferred to Personnel Accounting as Supervisor - Benefit Plans Accounting.

A new report numbering system was adopted for the General Accounting Operation and is to be used for December reporting.

The amount of outstanding cash advances as of December 31, 1956 was $\$ 4,460$; a decrease of $\$ 3,425$ from the previous month.

The quarterly physical Inventory of Special Materials and Precious Metals was taken by custodial personnel in December. The semlannual Gold Report for the six-month period ended December 31, 1956 was submitted to Contract Administration.

The balance of FY 1957 Budget for Attendance at Off-Site Courses and Seminars was $\$ 2,538$ at December 31, 1956; while the balance for Attendance at Professional Trade Socleties and Meetings was $\$ 11,444$.

Depreciation Expense applicable to Reactor areas was recast by calendar years 1952 through 1956.

Unitization of projects is current. Greatest emphasis in this area is placed on Unitization of CG-558 - Pile Modification, 100-B Area, and CA-512 - KRR Test Facility.

A review of the Equipment Budget was made to determine the additional funds required for the balance of FY 1957. Each Level III Nanager was contacted, and each item in his Budget was carefully scrutinlzed. A letter was drafted to the General Manager of HAPO requesting additional funds for IPD. 
A letter for Contract Administration was prepared presenting the estimated subtal date to $A E C$, estimated starting date and the estimated completion date each project included in the FY 1957 Equipment Budget Midyear Revlew.

The records on Obligation of Funds were brought up to date; these records are maintained to provide necessary information in preparation of plant acquisition and construction budget.

Seven project proposals and three appropriation requests were reviewed during December. Budget Status was provided for six proposed projects.

Effective in December, IPD Projects which are flnanclally reported by Facilities Engineering Cost, will be charged overhead at the rate of $5 \%$ of project cost, exclusive of Design Costs. This charge is to be made retroactive to September 1,1956 and will amount to $\$ 9,000$ for the four months. Purchasing, Inspection and incremental costs make up this overhead.

The "Summary Cost Report and Estimate" formerly issued by CEO cost, covering projects for $\$ 200,000$ or more, where the major portion of construction work is done by CPFF forces was issued by Facilities Engineering Cost for all IPD projects in this category.

Weekly time distribution records, formerly reported on individual cards, are now reported on one summery sheet per week for each Unit in Facilitles Engineering Operation.

auct Cost and Budgets

Appraisals were completed for all exempt personnel. Job descrlptlons were written for five key nonexempt jobs and were submitted to Wage Adminfstration for review and rating.

Analyses were made of Research and Development and Process Technology costs in comparison with allotted funds for the Manager, Research \& Engineering. The Manager of Finance, Hanford Laboratorles, was provided with an analysts of costs incurred by the Labs related to funds available.

Cost accumulation and analysis responsibilities for Facilities Engineering Operation were transferred to General Accounting Operation.

Meetings were beld with Plant Managers to discuss budgets, operating reports and speclal cost reports to give them a better understanding of how the reports can be of the most value.

Charts were prepared showing Essent1al Materlal Consumption by major material for all Plant and Power Operations.

\section{Personnel Accounting}

Effective December 1, 1956, isolation pay and area differential were included carnings for Insurance purposes. Prior to December 1, these payments Wire considered to be premium payments outside the scope of "normal straighttime annual earnings," the insurance plan bas1s. As a result of this change employees concerned have increased Iffe insurance coverage of approximately $\$ 960$ and increased weekly slckness and accident benefits of $\$ 5.00$ ner week. The Increased premium for these additional coverages is only about two cents per week. 
Mr. J. A. Leger was appointed Supervisor - Benefit Plans Accounting effective December 15, 1956.

Puyroll master files were handled on a consolldated basis through December 31, 1956, because of the necessity to complete the calendar year for tax reporting purposes. Tax reporting numbers have now been assigned each separate HAPO component and the appropriate card files have now been decentralized. This is the final phase in the decentralization of the Personnel Accounting function. The salary bank accounts have not been decentralized, of course, because of the extra cash requirements which would then become necessary.

Auditing

A report was 1ssued covering the result of a verification of health claim benefit payments to or on behalf of selected IPD employees during the month of May, 1956. The verification was undertaken at the request of $\mathrm{K}$. H. Ayer Insurance Plans Accounting, Schenectady.

Employee and Timekeeping data pertinent to the problem of installation of time recorders for nonexempt employees in IPD was compiled and reported.

D. P. Slater was transferred from Personnel Accounting to Auditing dutles as of December 3, 1956.

\section{Procedures}

A survey of processing operation forms was made with a view to determining which forms come to all or most all areas for sufflclent usage to warrant their establishment in Stores stock. Returns from the survey developed numerous requested forms revision which are being co-ordinated in order to hold the number of forms to a minimum.

Work was continued on the subject of a teletype of facsimile communications system and automated procedures which might serve personnel records and Salary and Wage Administration as well as other components of the Department in overcoming communication problems.

The study of work orders has developed to a polnt at which a preliminary report is desirable and such a report is now in the process of being developed.

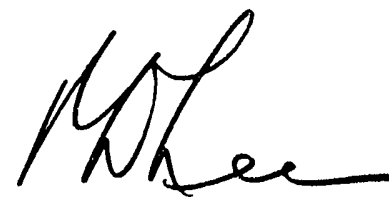

Manager-Finance IRRADIATION PROCESSIITG DEPARIMIENT

PD Lee: $k \mathrm{kh}$ 

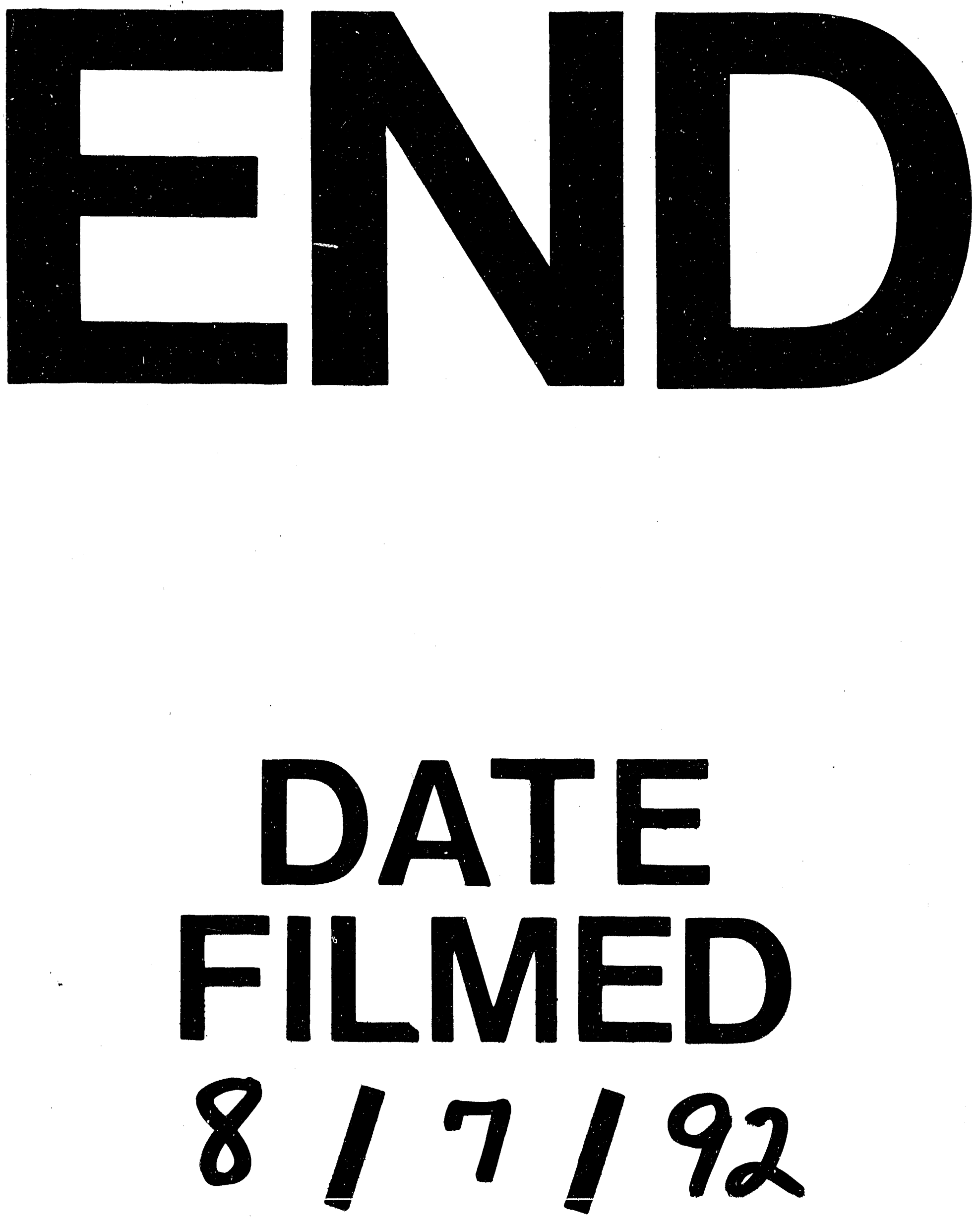
